\title{
Ameliyathane Performanslarının İç Kullanıcı Memnuniyeti Açısından İncelenmesi; Erciyes Üniversitesi Gevher Nesibe Hastanesi Örneği
}

\author{
Z. Özlem PARLAK BiçER ${ }^{1 *}$, Cihangir BiçER ${ }^{2}$, Adnan BAYRAM $^{2}$, \\ Sümeyye BOZDOĞAN ${ }^{3}$
}

Öz

Bu araştırmanın amacı, hastanelerin özellikli mekanlarından olan ameliyathane mekan performansının, iç kullanıcı olarak nitelendirilen ameliyathane akademik ve idari kadroda çalışan personelinin meslek, yaş, cinsiyet değişkenleri bazında irdelenmesidir. $\mathrm{Bu}$ araştırma, iç kullanıcı tarama modeli esaslarında gerçekleşen bir çalışmadır. Çalışma grubu; Erciyes Üniversitesi Tıp Fakültesi, Gevher Nesibe Hastanesi ameliyathanelerinde çalışan ve anketi yanıtlayabilen tüm personelden oluşmaktadır. Ameliyathanede çalışan 89 personel, yani çalışanların çoğunluğu, çalışmaya katılmışlardır. Araştırmada, katılımcıları tanımaya yönelik olarak, yaş, meslek, cinsiyet, eğitim, çalışılan bölüm soruları ve mekan performans algısına yönelik estetik, konfor, işlev soruları sorulmuştur. Bunun için; tarafımızca geliştirilen Mekan Algısı Ölçme Anketi (MAÖA) geliştirilmiş ve kullanılmıştır. Hastanelerin en önemli birimi olan ameliyathanelere yönelik yapılan çalışmanın sonucunda, mimari mekânın işlev yönü ile kalitesi ve yapı elemanlarının performansı belirlenmiştir. Bu araştırmaya katılan ameliyathane akademik ve idari personelinin mekanın ISı, aydınlatma gibi konularda farklı algıları olduğu için mekan iç ortam ölçümlerinin iç kullanıcı yaş, cinsiyet, meslek değişkenleri ile yapılma gerekliliği ve özellikle iç kullanıcının dinlenme alanlarında rahatlatıcı mekan verilerinin kullanılması gerekliliği bulunmuştur. Ayrıca mevcut ameliyathanelerde gelişen teknolojiye göre cerrahi odaların yeniden planlanması, yeni yapılacak ameliyathaneler için de cerrahi odaların bu teknolojileri düşünerek tasarlanması önerilmektedir. Çalışmanın ameliyathanelerin mekânsal ve yapı elemanlarına yönelik kullanıcı memnuniyeti ve toplam kalite yönetimine, mimar, hastane yönetimleri ve mevzuata yapılacak çalışmalara katkı sağlaması umulmaktadır.

Anahtar Kelimeler: ameliyathane, performans ölçümü, kullanıcı memnuniyeti, ergonomi

\section{Investigation of Operating Room Performances in Terms of Internal User Satisfaction; an Example of a University Hospital}

\author{
Abstract \\ The purpose of this study is to examine the operating room space performance, which \\ gender variables of the staff working in the academic and administrative staff, which is \\ considered as internal users. This research is done on the basis of internal user

\footnotetext{
${ }^{1}$ Erciyes Üniversitesi Mimarlık Fakültesi, Mimarlık Bölümü, Kayseri TÜRKIYE

${ }^{2}$ Erciyes Üniversitesi Tıp Fakültesi, Anestezi ve Reanimasyon Anabilim Dalı, Kayseri TÜRKIYE

${ }^{3}$ Erciyes Üniversitesi Mimarlık Fakültesi, Kayseri

* Ilgili yazar/Corresponding author: parlako@erciyes.edu.tr

Gönderim Tarihi / Received Date: 30.01.2021

Kabul Tarihi / Accepted Date: 03.08.2021
} is one of the special places of the hospitals, on the basis of occupation, age and scanning model. Working group; Erciyes University Faculty of Medicine consists of all 
personnel working in the operating rooms of the Gevher Nesibe Hospital and who can answer the questionnaire. 89 staff working in the operating room, ie the majority of employees, participated in the study. In the research, the questions of age, profession, gender, education, departments studied, and aesthetics, comfort and function questions regarding perception of space performance were asked in order to get to know the participants. For this; The Space Perception Measurement Quastinarie (TSPMQ) developed by us was developed and used. As a result of the study conducted for the operating rooms, which are the most important unit of the hospitals, the function direction and quality of the architectural space and the performance of the building elements were determined. As the operating room academic and administrative staff participating in this research had different perceptions on the subjects such as the temperature and lighting of the space, it was found that the indoor environment measurements should be made with the variables of internal user age, gender, occupation and the use of relaxing space data especially in the rest areas of the internal user. In addition, according to the developing technology in the existing operating theaters, it is recommended to plan the surgical rooms from the ground, and for the new operating theaters, the surgical rooms are designed by considering these technologies. It is hoped that the study will contribute to user satisfaction and total quality management of spatial and structural members of operating theaters, architects, hospital administrations and studies to be conducted in the legislation.

Keywords: operating room, performance measurement, user satisfaction, ergonomy

\section{Giriş}

Teknolojinin ve bilimin gelişmesiyle beraber sağlık anlayışında da farklılıklar olmuştur. Günümüzde halk sağlığında, hastalık olgusu oluşmadan sağlığın korunması veya iyileştirilmesi ön plana çıkmaya başlamıştır (Biçer vd 2001, s. 26-31; Tezcan vd. 2000, s. 47). İnsanoğlu, hastalıklarını iyileştirebilmek için tedavi olabilecekleri mekâna intiyaç duymaktadır. Hastaneler, bu ihtiyacı karşılayan günümüzdeki sağlık koşullarını sunan mekânları oluşturmaktadır. Geçmişten beri mekânsal, teknolojik, kurumsal vb. konularda çok hızlı bir şekilde gelişen sağlık kurumları, insanların sağlık yönünden intiyaçlarını karşılamaktadır (Yıldııım ve Muslu 2006, s. 39-51). Hastaneler insanların günlük yaşam alanlarından ve yaşam biçimlerinden farklı ortam ve mekânları içermektedir. Hastanelerde tedavi için konaklama tedavi süreci, tanı, teşhis gibi kavramlar, insanlar üzerinde biyolojik, fizyolojik ve ruhsal yönden negatif bir izlenim ve etki oluşturmaktadır. Hastane kurumlarındaki olumlu fiziksel çevre, insanları fiziksel, ruhsal ve sosyal yönden pozitif etkilendiğinden dolayı diğer kurumlara kıyasla çok daha önemlidir (Yıldırım ve Muslu 2006, s. 39-51). Çoruh'a (1998) göre "Kalite Kavramının sürekli kendini yenilemesi ve toplumun gereksinimlerine yanıt vererek gelişmesinin yolu, bu kavram aracılığıyla ortaya çıkacak zorunlulukların ve bunların ne derece uygulanabildiğinin sıkı şekilde takip edilebilmesinden yani ölçülebilmesinden geçer" (Çoruh, 1998, s. 4-5). Bu ifadeden anlaşıldığı gibi kalite ve memnuniyetin sürekliliği ve verimi için rutin olarak kaliteyi ve memnuniyeti artıracak etmenleri denetlemek ve güncellemek gerekmektedir. Sağlık hizmeti, birçok faktörü içinde barındıran organizasyonların bileşiminden oluşmaktadır (Çıraklı ve Sayım, 2009; Aslan ve Özata, 2005, s. 554-565). Kalite hasta memnuniyetini anlama ve karşılama konusunda önemli bir etmendir. Hasta memnuniyetini ölçmede verilen hizmetin kalitesi ve süresi, teşhis, tedavi, bakım gibi çeşitli unsurlar etkin rol oynamaktadır (Tarım, 2000, s. 1027). Bireylerin, sağlık hizmetine ihtiyaç duymaları ve gelişen teknoloji sonucunda, sağlık hizmetinden beklentileri değişmiştir. Kaliteli hizmet uygulaması ile bireyler daha seçici davranmış ve kaliteli hizmet sunulması gündeme gelmiştir. Sürekli hizmet veren bir sağlık kurumu kullanıcılarının kurum hakkındaki isteklerini, beklentilerini ve sağlık 
kurumundan memnunluk derecelerini araştırmak, değerlendirmek ve sonuçlara göre nasıl bir hizmet sunulması gerektiğini tasarlamak önemlidir. Teknolojinin ve bilimin gelişmesi ise kalite beklentisini de arttırmıştır. Sağlık alanında hizmet sunumunda doğabilecek hatalar veya yetersizliklerden dolayı kalite kavramı çok önemli bir konuma gelmektedir (URL-1, 2008). Strasen (1988) 'hasta memnuniyeti, klinik sonuçlar kadar önemlidir ve bunu ölçmek her sağlık kuruluşunun hedeflerinden biri olmalıdır.' görüşündedir (Strasen, 1988, s.5-6). Bu bakımdan kalite ve memnuniyet kavramı insanlar bilinçleştikçe hayatımızda daha önemli bir konuma sahip olmaya başlamıştır. Sağlık sektöründeki kullanıcılar, hastane mekânlarını kullanan hizmet alan veya veren tüm kişilerdir. Hastanelerde kullanıcı profili, iki grupta incelenmektedir. Bunlardan ilki iç müşteri olarak tanımlanan sağlık kurumunda çalışan veya sağlık kurumuyla iletişim halinde bulunan, sağlık çalışanları olarak bilinen doktor, hemşire, farklı konularda hizmet veren sağlık teknisyeni, sağlık hizmetlileri vb. kişi ya da gruplardır. İkinci kullanıcılar ise dış müşteri olarak tanımlanabilecek bir sağlık kurumunun sunduğu hizmetlerden doğrudan ya da dolaylı olarak yararlanan kurumları, hastalar, hasta yakınları ve ziyaretçileri oluşmaktadır (Kavuncubaşı, 2000, s. 399). Bu çalışmada iç kullanıcı olarak adlandırılan kesim üzerinden alan çalışması gerçekleştirilmiştir. Hastanelerin özellikli bölümlerinden olan ameliyathane iç kullanıcıları çalışmada yer almışlardır. Sağlık yapılarını sadece hastalar ve hasta yakınları kullanmamaktadır. Memnuniyet kapsamına hastane çalışanları da girmektedir. Bu doğrultuda ameliyathane çalışanlarının sağlık kurumundan beklentileri önemlidir. Özellikle yeni uygulamaya geçirilmeye çalışılan iş sağlığı ve güvenliği konusuna yönelik yasal mevzuatlarda da yer alan çalışma ortamının durumuna yönelik uygulamalar, konunun önemini vurgulamaktadır.

Hastalar, hasta yakınları ve hastane çalışanları için mekânsal memnuniyet ve kalite önemli bir konudur. Fakat ülkede sağlık yapılarına yönelik, kullanıcı memnuniyeti odaklı çalışmalar sınırlı kalmıştır. Her iki kullanıcı grubu için de mekansal memnuniyet önemli olmaktadır. Bu durum, toplam kaliteyi de beraberinde getirmektedir. Ülkemizde hastane yapılarına yönelik olarak fazla çalışma yapılmadığı bilinmektedir (Ergenoğlu ve Tanrıtanır, 2013, s. 61-75). Hastanelerde mekânsal olarak yapılacak ve kullanıcı memnuniyetinin içeren alan çalışmalar, önemli görülmektedir. Hastane yapıları birbirinden farklı kullanıcıların intiyaçlarını ve isteklerini karşılayacak nitelikte olmalıdır. Kullanıcı memnuniyeti arttıracak mekânsal düzenlemelerin tasarım ve yapımında alan çalışmalarını içeren geri besleme sayesinde, ameliyathaneler ve dolayısı ile hastaneler artık sadece klinik hizmet veren mekânların dışında fiziksel ve ruhsal iyilik halinin yükseltilmeye çalışıldığı alanlar olmalıdır. Böylece her iki kullanıcı gurubunun mekânsal memnuniyetleri artırılacaktır. Hastane yapıları tasarlanırken dış ve iç kullanıcıların kolay erişebilir, güvenilir, nitelikli ve keyifli, stresi azaltan, ruhen ve fiziksel olarak iyileşmeye pozitif etkisi olabilecek mekânların olması önemlidir. Diğer kamu yapılarına göre daha kompleks ve yoğunluklu bir planlama ve kurgu gerektiren hastane yapılarının plan ve mekân kurgusunun iç ve dış kullanıcı grubundaki insanlara hitap etmesi önemlidir (Gezer, 2014, s.113-133). Değişim ve dönüşüm olgusu mimarlıkta ve mimari ürünlerde sıklıkla görülmektedir. Mimarideki bu değişimin hastane yapılarında ve mekanlarında daha fazla olduğu düşünülmektedir (Ergenoğlu ve Aytuğ, 2007, s. 4463). Bu durum, özelikle gelişen teknolojinin yoğun kullanıldığı alan olan sağlık alanının yeni mekânsal intiyaçları ve değişen politikalar sebebi ile şehir hastanesi gibi kavramların oluşması gibi faktörlere bağlı olarak hastanelerde daha fazla belirginleşmektedir. Yapılan hastane tasarımlarında; kaliteyi arttırarak kullanıcıların psikolojik, ergonomik, fizyolojik olarak mutlu ve rahat bir ortam tasarlamak, önemli bir amaç haline gelmektedir. Bu bağlamda; 'iyileştiren hastane' ve 'hastanelerde kalite' ön plana çıkmaktadır. İyileştiren hastane; Hastane ortamının; sosyal, manevi, psikolojik, estetik, hayat standartlarını konforunu artıran, iyileştirici, rahatlatıcı, güven verici, 
ergonomik, ışık, ses, renk ve malzemeye yönelik istekleri karşılayan alanlardan oluşması gerekmektedir. Hastanelerde tasarım kalitesi konusu, mekan standartları ve maliyet ile birlikte kullanıcının ergonomik, psiko-sosyal kalitesini de düşünmeyi gerektirmektedir (Ergenoğlu ve Aytuğ, 2007, s. 44-63). Hastaneler içerisindeki özelleşen önemli alanlardan olan ameliyathanelerde bu beklentilerin, hayati önem taşıyan işlerin gerçekleştirildiği mekanlar olması sebebi ile daha da yükseleceği düşünülmektedir. Hastane yapılarında aydınlatma, ses-gürültü, hastane planlaması, erişilebilirlik gibi konular, kullanıcı memnuniyetini önemli derece etkilemektedir. Bu açıdan, tasarımcılara bu konuda büyük bir yük düşmektedir. Aydınlatma için Bayar (1994), uygun ve gerekli aydınlatmayla görsel konforun sağlanması gerektiğini yoksa yanlış teşhis -tanı, çabuk yorulma, göz hastalıkları gibi belirtilerin ortaya çıkacağı, bundan dolayı aydınlatma şeklinin ve konforunun iyi bir şekilde oluşturulması gerektiğini vurgulamıştır (Bayar, 1994, s. 77-79). Ses ve gürültü için Şentürk (1994), bu kavramların sağlık alanında ne kadar önemli olduğunu ve çalışan personellerin bu konuda eğitim almaları gerektiği, kullanılan araç, gereç ve malzemelerin sürekli kontrol edilip, bakımının yapılması ve ses ve gürültü oluşturmayacak kalitede olması, çalışanların kullandığı ayakkabıların ses çıkartmayan türde olması gerektiğini belirtmiştir (Şentürk, 1994, s. 28-31). Hastane planlamasında, sağlık yapıları kullanıcıları için kaliteli tasarım ölçütleri, net bir planlama, denetim altına alınmış fiziksel değişkenler, denetim ve iç mekân tasarımının kullanıcıları moral ve sosyal düzeylerini iyileştiren ve geliştiren bir planda olması gerektiği ifade edilmiştir (Tüker, 1996). Sağlık yapılarında erişilebilirlik kapsamında, yapıların planlamasında mekan boyutlarının, yüzeylerinin, bildirişim elemanlarının gerekli yönlendirme ve uyarı işaretlerinin standartlar doğrultusunda erişilebilir olması gerekmektedir (Gezer, 2014, s. 113-133). Sağlık yapıları içerisinde yer alan ameliyathane bölümlerinde ise bu belirlenen fiziki şartların üst düzeyde karşılanması, mimarinin planlama ve yapımdaki rasyonel çözümleri gerektiren sorumluğudur. Kısacası sağlık yapılarında tasarımcının yaptıkları kullanıcının memnuniyetini ve sağığını önemli derecede etkilemekte olduğu için tasarımcılara büyük bir sorumluluk düşmektedir. Hastaneler içerisinde özelleşen mekânlardan olan ameliyathaneler, iç kullanıcı olarak görülen cerrahlar için hastanede en önemli yerdir. Cerrahi uygulamadaki hıza ve tahmin edilemeyecek düzeydeki yeniliğe rağmen, ameliyathanelerde mekân olarak nispeten daha az ilerleme kaydedilmiştir. Alanı kalabalıklaştıran yeni teknolojiler içerir cihazlar gelmesine karşın, ameliyathanelerin planlarındaki değişiklikler ve mekânın nasıl düzenleneceği konusunda büyük ölçüde değişim olmamıştır. Ameliyathane iç kullanıcılarından cerrahların belirlediği tasarım eksikliğinin birçoğu; tehlikeli bir ortamın ifadesi olan "ekipmandaki hatalar, gerekli öğelere erişilemezlik, iletişim sorunları, malzemelerin verimsiz işlenmesi, tartışılmaz gecikmeler" bugün de cerrahlar tarafından belirlenmektedir. Daha iyi bir ameliyathane inşa etme sorunu her zaman olmuştur. Ameliyathane kullanıcıları ve mimarlar arasındaki bilgi boşluğu ise bu sorunu kuvvetlendirmektedir. Ameliyathane iç kullanıcıları olan cerrahlar, hemşireler vd sağlık personelinin mekânı planlama aşamasındaki önerileri ve sonuçta elde edilen mekân arasındaki fark ise konu üzerinde cesaret kırıcı bir yön olmaktadır. Bunun yanı sıra mimarların, iyi iletişim kuramamaları, bütçe ve malzeme gibi sınırlamalar ile karşılaşmaları da olmaktadır. Ayrıca bu kısıtları aşabilmek adına mekânda yapılan revizyonlar ile planın da tanınmaz hale gelmesi söz konusudur. Bir ameliyathane tasarlanırken mimarların cerrahi personeli odak grubu seçmeleri söz konusudur. Bu odak gruplarından elde edilen kullanıcı girdisinin ise tasarımda veri olarak kullanılması yine yetersiz kaldığı söylenmektedir. (URL-2, 2017). Bu çalışmada; ameliyathaneler için gerekli olan kullanıcı girdisine yönelik alan çalışması gerçekleştirilerek çözüme katkı koymak da amaç edinilmiştir. Sağlık Bakanlığı tanımına göre ameliyathaneler "yoğun bakım odaları, hasta hazırlık ve ameliyat sonrası bekleme alanları, ayılma odaları, ameliyathane koridorları, sedye transfer alanları, ameliyathaneler hastanelerin 
cerrahi üniteleri"ni kapsamaktadır (T.C. Sağlık Bakanlığı İnşaat ve Onarım Dairesi Başkanlığı, 2019). Yukarıda bahsedildiği gibi iç kullanıcılar, bu mekanların tümünde ve özellikle cerrahi alan olarak belirlenen ameliyathaneler ve ameliyathane koridorlarını etkin bir şekilde kullanmaktadırlar. Bu kullanım durumuna rağmen genel ameliyathane trafiğinden uzaklaştırılması önemli bir konudur. Cerrahi ünitelerine erişimde mutlaka bir giriş alanı ve bununla birlikte ameliyathanelerde hastaların sedye değişimi için yeterli alan olmak zorundadır (T.C. Sağlık Bakanlığı İnşaat ve Onarım Dairesi Başkanlığı, 2019). Sağlık Bakanlığı tarafından belirlenen ve bir ameliyathanede zorunlu olacak düzenlemeler vardır. Buna göre; ameliyathane girişinde hasta yakınlarının beklemeleri için alanları, klinik büyüklüğü, hasta sayısı ve refakatçi durumuna göre planlanmalıdır. Ameliyathane girişlerinde hasta yakınlarının bilgi alabilecekleri bir mekân da tavsiye edilmektedir. İlgili mevzuatta ameliyathane cerrahi alanları "kirli, yarı steril ve steril alanlardan oluşan" özel alanlar olarak tanımlarken steril alanlar; "ameliyathane ve steril yoğun bakım odaları" olarak tanımlanmaktadır. Cerrahi alanlar ayrıca "yarı steril alanlar; hastaların ameliyata hazırlandığı ve sonrasında bekletildiği, ayılma odaları, ameliyathane koridoru ve sedye transferi yapılan alandan ameliyathaneye kadar olan kısım"ı kapsamaktadır. Bir diğer steril olma durumuna göre tanımlanan kirli alanlar ise; "sedye transferinin yapıldığı kısmın dış tarafı, girişteki bekleme alanları, personelin kıyafet değiştirdiği alanlar, duş ve tuvaletler, ameliyathane kirli malzeme odası ve koridor"larını kapsamaktadır. Yapılan çalışmada bu alanların hepsini kullanan personel çalışmaya katılarak değerlendirme yapmaları istenmiştir (T.C. Sağlık Bakanlığı İnşaat ve Onarım Dairesi Başkanlığı, 2019).

Cerrahi ünitesini ilgilendirmeyen trafiğin cerrahi ünitesi içinden geçmemesi, ünitenin bir giriş alanı olması, gerek Acil Servis'ten, gerekse Yoğun Bakım Ünitesi'nden kolay ulaşım sağlanması gereklidir. (T.C. Sağlık Bakanlığı İnşaat ve Onarım Dairesi Başkanlığı, 2019). Ameliyathane bölümünde, girişin önünde sedye transferinin yapıldığı bir alan olması, hastaların hazırlandıkları alanlar, sedye transferinin yapılmadan önceki alanlarda olması istenmektedir. Orta büyüklükte bir ameliyathane $\left(42 \mathrm{~m}^{2}\right)$ duvar uzunluğu en az 6 m olacak şekilde tasarlanıp mekânda cerrahi ünitesi kontrol istasyonu ve acil durumlarda iletişim kurmak için bir sistem kurulumu istemektedir. Büyük ölçekli ameliyathanelerde de $\left(50 \mathrm{~m}^{2}\right)$ en küçük duvar uzunluğu yine aynıdır. Farklı cerrahi müdahalelere uygun tıbbi donanımın yerleştirilmesi ve kullanılması (Şekil 1., Şekil 2.) için kullanım durumuna göre ameliyathane ile birleşen ek bir oda, sabit veya duvara monte dolap ve gömme raflar düşünülmeli (Şekil 3) ve kullanıma göre gerekli tesisat ve elektrik bağlantıları temin edilmelidir (T.C. Sağlık Bakanlığı İnşaat ve Onarım Dairesi Başkanlığı, 2019). Ameliyat öncesi ve sonrası için de cerrahi ile bağlantılı mekanları için de düzenlemeler bulunmaktadır. Buna göre; iki ameliyathane ve üzeri için hastaların ameliyata hazırlanmalarına yönelik alan olmalıdır. Her, anestezi sonrası bakım ünitesi en az bir kapı ile hastanenin genel koridorlarını geçmeye gerek kalmadan, cerrahi ünitesinden doğrudan uyanma odasına erişimi sağlamalıdır. Bu mekânların sayısı ikiden az olmamalıdır (T.C. Sağlık Bakanlığı İnşaat ve Onarım Dairesi Başkanlığı, 2019). Bu alanların yanı sıra yine ameliyathanelerde cerrahi bölümlerin servis alanları diğer önemli mekânlardır. Her ameliyathane girişinin yanına, iki yıkanma/fırçalanma alanı tasarlaması gereklidir. İki ameliyathanenin girişleri aynı alanda ise her ikisi için tek alan tasarlanabilir. Bu bölümler yakındaki personel, donanım yada malzemelere sıçramayı önleyecek biçimde ve ana trafikten uzak olmalıdır (T.C. Sağlık Bakanlığı İnşaat ve Onarım Dairesi Başkanlığı, 2019). Sağlık Bakanlığı'nın yönlendirici kılavuzu, geleceğin ameliyathanelerinin mekansal gerekliliklerini ise ele alamamıştır. Robotik cerrahi ve buna yönelik mekân boyutları ve tasarımı da önemli bir konudur. Geleceğin ameliyathanesinde hasta hareketinin zemin planı ve akış diyagramında (Şekil 4.) önce hastalar ana kayıt alanından (1) indüksiyon alanına (2) getirilir. Ameliyat öncesi hazırlık ve anestezi indüksiyonu indüksiyon 
alanında (2), ameliyathanede (3) cihaz kurulumu ile birlikte gerçekleştirilmektedir. Anestezi uygulanmış hastaların cihaz kurulumu tamamlandıkça ameliyat için ameliyathaneye (2 ve 3 ) aktarılacak şekilde ayarlama yapılır. Ameliyatın sonunda hastalar ameliyathanedeki anesteziden çıkar ve erken iyileşme alanına $(3,4)$ aktarılır oradan da hastalar postanestezi bakım ünitesine (4) aktarılır (22). Robotik donanım kullanımı için ayrıca ameliyat gerçekleşen alan ile bağlantılı teknik mekânlara intiyaç varır (Şekil 4). Bu çalışmada ele alınan Erciyes Üniversitesi ameliyathanelerinde bu tür bir operasyon gerçekleştirilmediği için bu tür bir mekân ele alınmamıştır.
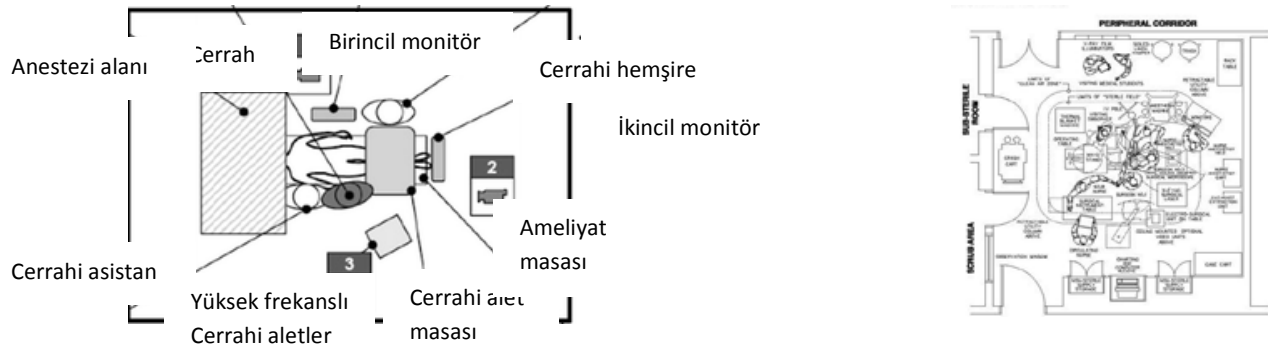

Şekil 1. Ameliyathane İç Kullanımı (URL-3, 2020)

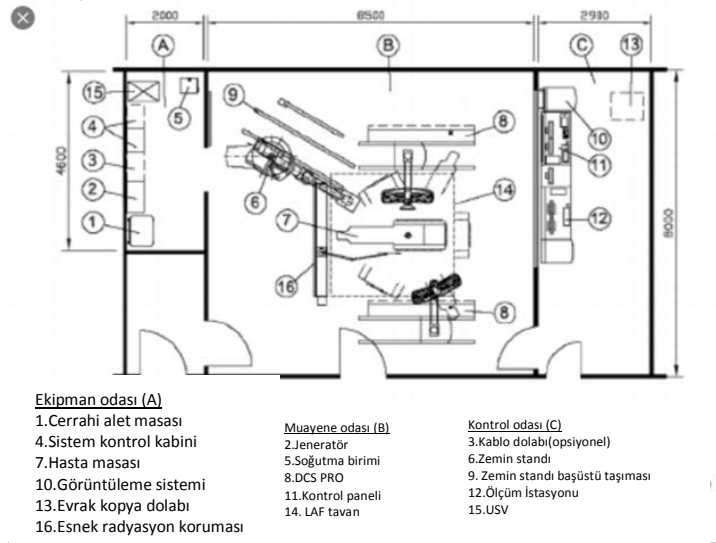

Şekil 2. Büyük Ölçek Ameliyathane İç kullanımı (URL-4, 2020)

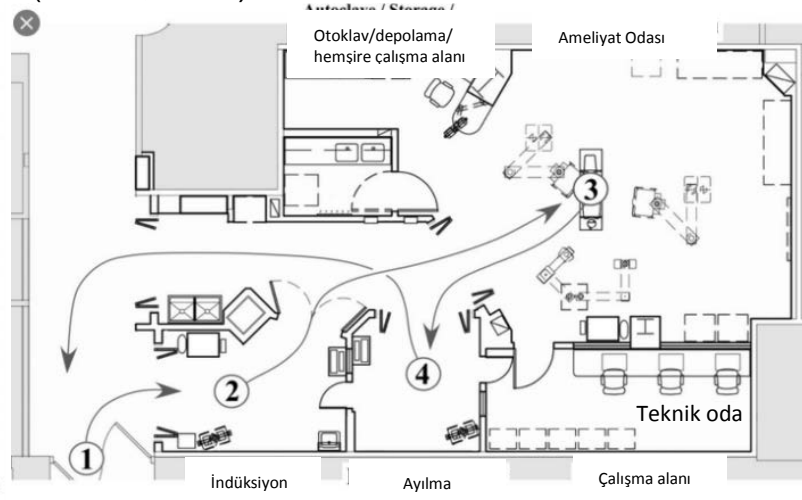

Şekil 3. Ek odalı Ameliyathane (URL-5, Şekil 4. Robotik ameliyat yapılan mekânın 2009) kullanım durumu (URL-6., 2005)

Bu çalışma Kayseri Erciyes Üniversitesi Gevher Nesibe Hastanesi ameliyathanelerin incelenmesi ile ameliyathanedeki iç kullanıcıların memnuniyet durumu, farklı açılardan ele alınan kalite ölçümü yapılarak mimari tasarımların kullanıcılar üzerindeki etkisi somut bir şekilde ortaya koymak amaçlanmıştır. Kayseri Erciyes Üniversitesi Gevher Nesibe Hastanesi ameliyathanelerinin seçilme sebebi ise Kayseri'de hastane olarak son derece yoğun, çok çeşitli kompleks ve heterojen hasta yapısına sahip büyük ölçekli kompleks bir ameliyathane yapısı içerisinde olmasındandır. Hastanede birçok farklı hizmet alan ve veren hasta odaları, bekleme salonları, ameliyathane, tedavi, teşhis odaları, vb. gibi farklı dış kullanıcı profiline sahip mekânlar bulunmaktadır. Ayrıca araştırma görevlisinden profesörüne farklı aşamadaki akademik ve hizmetlisinden teknisyeni, hemşiresine kadar farklı idari personelin bulunduğu dış kullanıcıya sahiptir. Hastane içerisinde özelleşen mekân olan ameliyathanedeki mekânların ve kullanıcıların çeşitliliği sayesinde yapılan çalışma, sağlık yapıları alanında önemli bir araştırma olmuştur. Çalışmada; ameliyathanede doğrudan veya dolaylı olarak hizmet veren kişilere bir anket uygulaması düzenlenmiştir. Bu anket çalışması ortamın mimari, estetik, ergonomik, açıdan kalitesini ve memnuniyet oranını ölçmesinde yardımcı olmuştur. Anketteki sorular bu amaca özel olarak hazırlanmış ve elde edilen bulgular çerçevesinde yapının iç kullanıcılar açısından ne tür bir sıkıntı yaşadıkları, hangi 
konulardan, memnun olup olmadıkları yapılan anket sonucunun değerlendirilmesi ile ortaya çıkarmak amaçlanmıştır. Çıkan sonuç çerçevesinde hastane yönetiminin ve/veya Sağlık Bakanlığı'nın alması gereken önlemleri ve geliştirmesi gereken konular irdelenerek öneri haline getirilmiştir. Bu çalışmada hastane içerisinde özelleşen mekânlar olan ameliyathaneler ele alınmıştır. Hastanedeki hasta odalarının bulunduğu servisler ve poliklinik gibi diğer bölümler ise başka çalışmalarda ele alınmıştır.

\section{Gereç ve Yöntem}

Hasta sayısı hastalık türü ve tipindeki değişimler doğrudan yapay çevreyi etkilemekte ve bu etkileşim mekan tasarımında önemli bir belirleyici olarak ortaya çıkmaktadır. Bu bağlamda, çalışmada; Erciyes Üniversitesi Tıp Fakültesi Gevher Nesibe Hastanesi ameliyathaneleri örnek uygulama alanı olarak belirlenmiştir. $\mathrm{Bu}$ belirlemede hastanenin, Kayseri'deki yoğun, çeşitli, kompleks ve heterojen hastaların tercih ettiği, her konuda tam teşekküllü hizmet sunmakta olan ve çevre illerden de hastaların hizmet aldığı, özellikle ağır vaka olarak tabir edilen hastaların hem poliklinik hem de ameliyathane hizmetleri için yönlendirildiği en büyük kuruluş olma özelliği göstermesi etkili olmuştur. Hastane, İç Anadolu Bölgesi içerisinde ve civar bölgelerdeki farklı yerleşimlerden gelen kullanıcılara, hastanede dâhili ve cerrahi her alanda hizmet sunulmaktadır. Hastanede farklı hizmet alan ve hizmet veren, hasta odaları, bekleme salonları, ameliyathane, tedavi, teşhis odaları, vb. gibi farklı kullanımlara hizmet eden mekanlar bulunmaktadır. Mekânların ve kullanıcıların çeşitliliği sayesinde yapılan çalışmanın, sağlık alanında katkı sağlayacağı açıktır. Yapılan bu çalışmada bu kullanıcılardan iç kullanıcı olarak tabir edilen hastane çalışanlarından ameliyathanede görev yapan her kademeden personel yer almıştır. Çevre illerden hasta alımı ile hastaneden hizmet alan farklı kültürlerden ve yaşam ortamlarından geldiği görülen kullanıcının hizmet aldığı hastanenin ameliyathanelerinde hizmet veren farklı iç kullanıcıların bulunması, çalışmanın güvenilirliğinin artmasına katkıda bulunmuştur. Ayrıca, bu durum, kullanıcının mekan üzerindeki beklentilerini ve algılamalarındaki farklıııkları da tartışma ortamına getirmiştir. Araştırma için çalışmanın yapılacağı sağlık kurumunun başhekimliği ile görüşülerek resmi izin alınmıştır. Bu çalışma, Erciyes Üniversitesi Rektörlüğü Sağlık Uygulama Ve Araştırma Merkezi Müdürlüğü'nün 44008645-010.99/65318 sayı ve 28.08.2015 tarihli izni alınarak yasal uygulamalar çerçevesinde gerçekleştirilmiştir. Çalışma, ameliyathanede gerçekleştirilen bir çalışmadır ama hayvan ve insan üzerinde gerçekleştirilen herhangi bir deneysel yöntem izlenmediği, mekan ve iç kullanıcı görüşü içerdiği için etik kurul kararına ihtiyaç yoktur. Çalışma için bahsi edilen idari izinler ise alınmıştır. Çalışma Helsinki Deklarasyonu Prensiplerine uygun olarak gerçekleştirilmiştir. Anketler; farklı alanlarda ve konumlardaki ameliyathane personelinin araştırmaya katılmalarında isteklilik/gönüllülük ilkesine özen gösterilerek gerçekleştirilmiştir. Bunun için; tarafımızca geliştirilen Mekan Algısı Ölçme Anketi (MAÖA) geliştirilmiş ve kullanılmıştır. Araştırmada; ameliyathanenin fiziki koşullarını ölçmeye yönelik ameliyathane iç kullanıcıları olarak çalışanlara mekânsal algı ve memnuniyeti içeren veri toplama gereci olarak anket yöntemi kullanılmıştır. Anket formu, 5'li Likert Ölçeği kullanılarak hazırlanmış 31 adet sorudan oluşmaktadır. Anketteki meslek, cinsiyet, yaş soruları ile kullanıcıları tanımlaması; çalışma süresi ile kullanıcının mekanı deneyimleme süreleri; ameliyathane mekan soruları ile mekan algıları ortaya koyulmaya çalışılmıştır. Ankette kullanıcıların cevaplarını 'çok kötü-kötü-kararsız-iyi-çok iyi' şeklinde 5 farklı derecelendirme ile cevaplaması istenmiştir. Çalışma; amacı kişilere anlatıldıktan sonra, ameliyathane hizmeti veren personelden, çalışmaya katılmayı kabul eden toplamda 89 kişi ile gerçekleştirilmiştir. Anketi cevaplayan çalışanlar sadece doktor ve hemşireler değil aynı zamanda teknik ve diğer hizmetleri gerçekleştiren ameliyathane personelinden oluşmaktadır. Hastane özelleşmiş birimi olan ameliyathaneler cerrahi ve 
servis birimleri üzerinde durularak incelenmiştir. İlki farklı branşlardaki cerrahi birimler, ikincisi ise koridorlar, hazırlık mekanları, yıkama/fırçalama üniteleri olarak değerlendirilmiştir. Çalışma, ortopedi, jinekoloji, genel cerrahi, beyin cerrahi, çocuk cerrahi, kulak-burun-boğaz, göz, göğüs cerrahi, üroloji ve plastik cerrahi odaları olmak üzere, toplamda 10 farklı branş ve bu branşların kendi içlerinde kullandıkları 13 farklı mekana göre değerlendirilerek yürütülmüştür. Çalışmada, ameliyathane birimlerinin çalışan iş kalitesini etkileyişi üzerinde durulmuş ve bu etkiler; işlev, psiko-sosyal ve teknik konular üzerinden irdelenmiştir. Anket çalışmasında ameliyathane mekan kalitesini ölçmeye yönelik; işlev, estetik-konfor ve güvenlik ana başlığı altında hazırlanmış ve farklı ameliyathane birimlerinde görev alan iç kullanıcı olarak nitelendirilen farklı ameliyathane çalışanlarına uygulanmıştır. Anket, anketi yanıtlayanı tanımaya yönelik, makan ile ilgili algılamaya ve çözümlere yönelik üç aşamalı sorulardan oluşturulmuştur. Bu çalışmada ameliyathanenin yönetimin özel izin ile her birimindeki ve her alanda çalışan personele anket uygulaması yapılması çalışmanın önemini artırmaktadır. Çalışmada mekânlar işlev, estetik ve konfor ve güvenlik başlıkları altında incelenmiştir.

\section{Bulgular}

\section{Erciyes Üniversitesi Gevher Nesibe Hastanesi Ameliyathaneleri}

Kayseri coğrafi konum itibari ile İç Anadolu ve diğer çevre illerden kolay ulaşılabilir durumdadır. Kayseri'de yer alan sağlık kurumları da bu coğrafi durum sebebi ile ulaşımı kolay olan bir yere sahiptir. Erciyes Üniversitesi ise Kayseri kent merkezine, havaalanına, çevre yoluna ve raylı sisteme mesafe olarak kısa ve kolay ulaşılabilir bir mevkie sahiptir (Şekil 5). Erciyes Üniversitesi'nin pek çok alanda eğitim-öğretim vermesi ile birlikte kuruluşundan itibaren bulunan Tıp Fakültesi'nin bulunması üniversitenin önem algısını artırmaktadır. Bunun yanı sıra Erciyes Üniversitesi Tıp Fakültesi'nin vermiş olduğu eğitim ve hasta tedavi hizmetleri de ülkede ve dünyada iyi bilinen bir seviyede bulunmaktadır. Ayrıca Tıp Fakültesi hastanesinin her alanda tam donanıma sahip olması, hastaların burayı tedavi için seçme tercihlerini artırmaktadır. Hastane tüm birimleri ile kampus içerisinde geniş bir yer tutmaktadır. Servislerin bulunduğu blok ise 12 katlı olup her katta ayrı bir branşın servisi olduğu gibi bazı katlarda iki ya da üç branş bir katı kullandığı duruma sahiptir. Hastanenin hizmet ettiği hasta sayısı arttıkça buna bağlı olarak ameliyathane yoğunlukları ve her ameliyathanenin kullanım süreleri de artmaktadır. Tıp Fakültesi bünyesinde 6 hastane, derslikler binası ve idari birimlerin yer aldığı dekanlık binası bulunmaktadır. Bu hastaneler kendi alanlarında, uzmanlaşılan hizmetleri sunmaktadır. Hastane yapıları içerisinde ilk ve en büyük kullanıma sahip olan Gevher Nesibe Hastanesi, iki kat poliklinik, ameliyathane ve yönetim kısmı ile 12 kattan oluşan servislerin bulunduğu ana bloğa sahiptir (Şekil 5). Bu çalışmada Gevher Nesibe Hastane yapısındaki ameliyathaneler ele alınarak inceleme yapılmıştır. Gevher Nesibe Hastanesi güneyinde iki katlı poliklinikler, polikliniklerin devamı ve yönetim birimlerinin bulunduğu iki kat üzerinde yatan hastaya hizmet veren 10 kat ile toplamda 12 katlı ana bloktan oluşmaktadır. Ana hastane bloğu, zemin ve ikinci katı ana poliklinikler, acil servis, ameliyathaneler ve öğretim elemanlarının yer aldığı birimlerden oluşmaktadır. Bu ana blok birinci katından ulaşılan ve hastanenin kuzeyinde ameliyathaneler konumlanmıştır (Şekil 6). Ameliyathanelerin kuzeyinde tek katlı olarak acil servis girişi yer almaktadır. Ameliyathane birimlerinden sadece göz cerrahi birimi acil servis ile aynı kotta bulunmaktadır. 


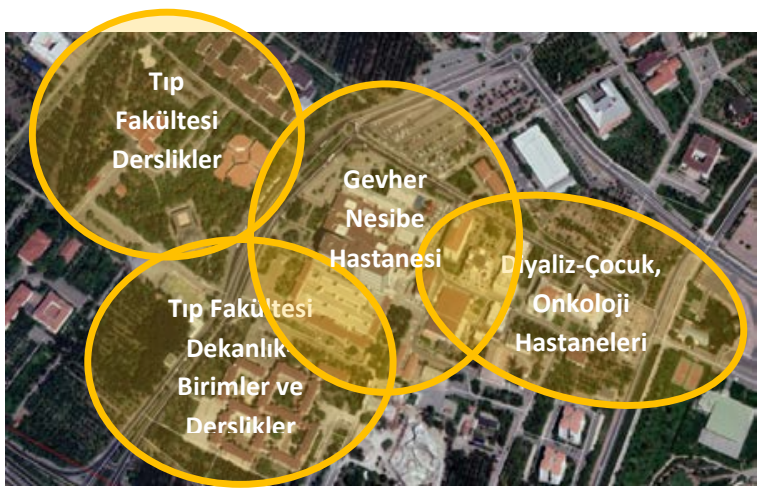

Şekil 5. Tıp Fakültesi'ne bağlı birimler (URL-8, 2020)

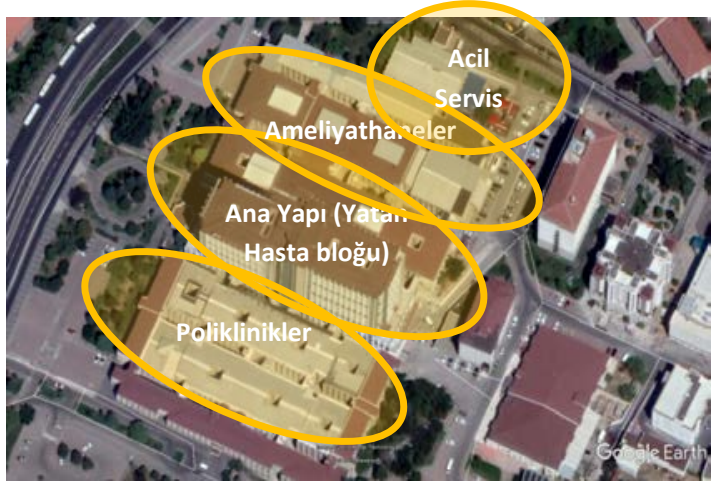

Şekil 6. Tıp Fakültesi Gevher Nesibe Hastanesi Bölümleri (URL-8, 2020)

Hastane planında iki hasta asansörü, bir öğretim elemanı asansörü bir servis asansörü ve üç genel kullanıma yönelik asansör ile merdivenin bulunduğu bir çekirdek bulunmaktadır. Çekirdeğin doğu batı yönüne doğru iki yanında ise hasta odaları bulunmaktadır. Bu hasta odalarının arasında koridorlar, toplu duşlar, wc, depolar ve genel sekretarya hizmetlerinin bulunduğu servis alanları mevcuttur (Şekil 9). Hastane ana bloğunun birinci katındaki bağlantı ile ameliyathanelere geçiş sağlanırken servislerden yatan hastanın ameliyathaneye geçişi, yapı çekirdeğindeki ameliyathaneye hizmet veren çift geçişli iki asansörler ile sağlanmaktadır (Şekil 7).

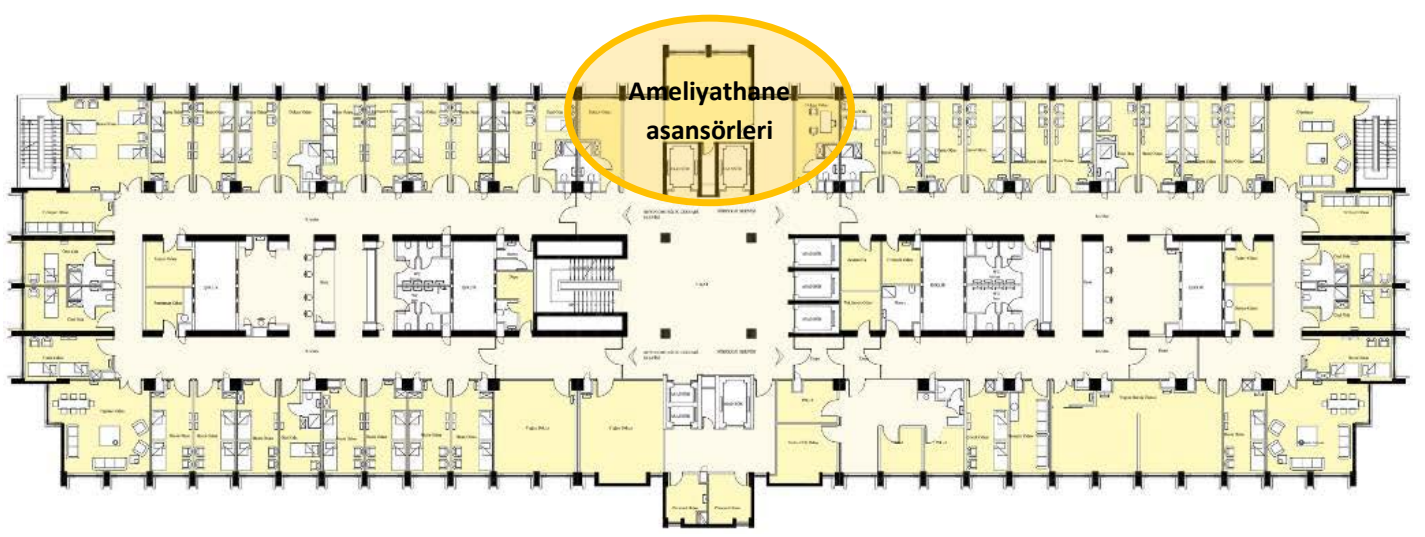

Şekil 7: Gevher Nesibe Hastanesi Kat Planı, (Argeus, 2016)

Erciyes Üniversitesi Tıp Fakültesi ameliyathaneleri, Sağlık Bakanlığı kılavuzuna göre büyük ölçekli ameliyathane sınıfına girmektedir. Ameliyathanelerde iki veya üç cerrahi ünite, ortak kullandıkları fırçalama/yıkma kısımları ile servis koridorlarına açılmaktadır (Şekil 8). Ameliyathanelerin her birinin kullanıldığı birime göre ayrı teknik odaları da bulunmaktadır (Şekil 8). Duvar uzunluklar en az $6 \mathrm{~m}$, Tavan temiz yüksekliği $3 \mathrm{~m}$ (Şekil $9 \mathrm{a}, \mathrm{b}, \mathrm{c})$ olarak tasarlanmış ve mekânlar $50 \mathrm{~m}^{2}$ olarak planlanmıştır. İç tefrişlerinde gerekli ameliyat donanımı olduğu gibi sabit dolaplar da eklenmiştir. Mimari tasarım açısından Sağlık Bakanlığı gerekliliklerinin yerine getirildiği bir ameliyathanedir. Ameliyathanenin her mekânında zemin, duvar tavan kaplama malzemeleri steril ortama uygun seçilmiş ve uygulanmıştır (Şekil 9 a, b, c). Ameliyathane servis mekânlarında kirli ve temiz ayrımı net yapılmıştır. Ayrıca iş güvenliği açısından "çok tehlikeli" iş yerleri içerisinde yer alan hastanenin ameliyathane bölümünde gerekli acil kaçış yollarının da gösterimi gerçekleştirilerek örnek bir uygulama gerçekleştirilmiştir (Şekil 9 a, b, c). 


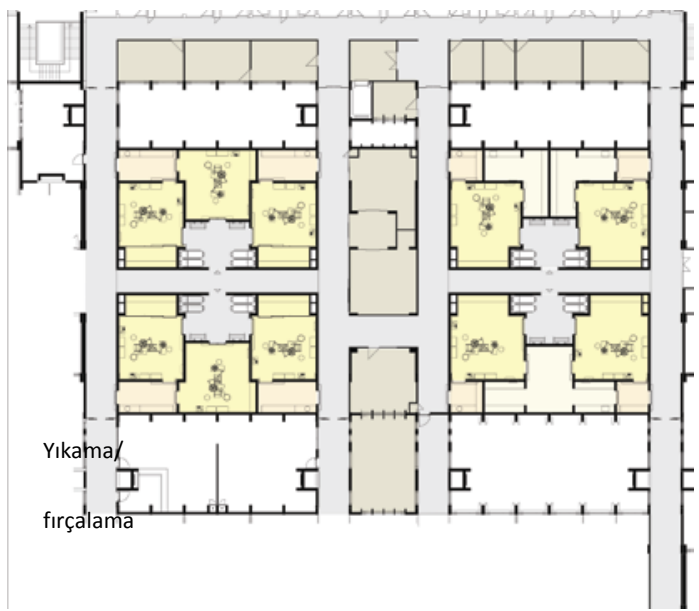

Şekil 8: Gevher Nesibe Hastanesi Ameliyathaneleri Planı, (Argeus, 2016)
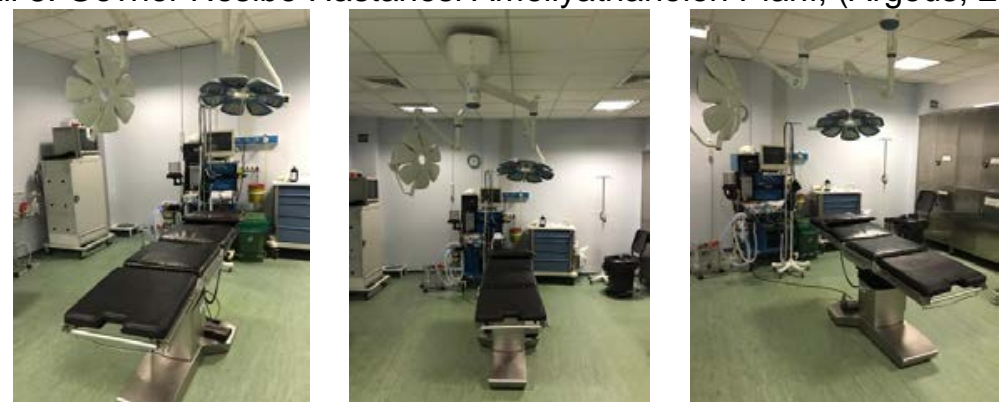

Şekil 9a. Ameliyathane İç Mekanları (Biçer, 2020)
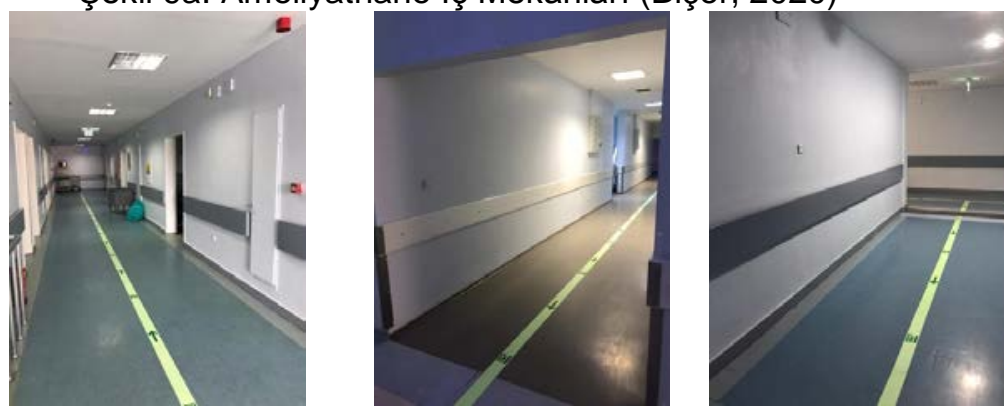

Şekil 9b. Ameliyathane İç Mekanları(Biçer, 2020)
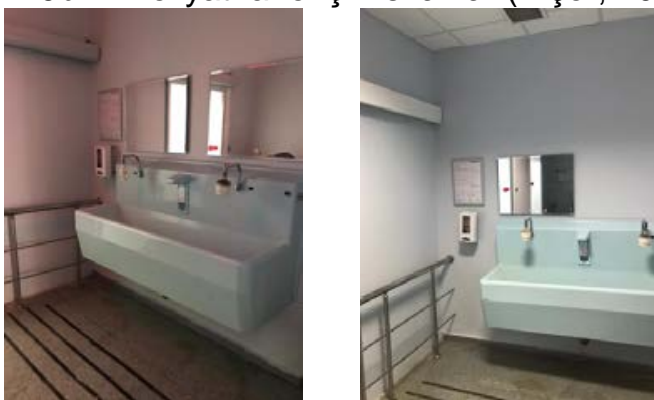

Şekil 9c. Ameliyathane İç Mekanları (Biçer, 2020)

\section{Ameliyathane İç Kullanıcı Cinsiyetine Göre Veriler}

Gevher Nesibe Hastanesi ameliyathane personeline uygulanan ve SPSS programı ile değerlendirme yapılan çalışmada; anketi cevaplayanların cinsiyetleri bir diğer önemli kriter olarak ele alınmıştır. Kişilerin cinsiyeti ve buna bağlı olarak çalıştıkları mekân algılamada farklılar yaratması üzerinde farklılıklar olacağı düşünülmüştür. Buna göre sonuçlar kadın ve erkek personel bağlamında değerlendirilmiştir. Ameliyathane iç kullanıcısı ile yapılan çalışmada mekân algısında cinsiyetin de önemli olduğu 
düşünülerek çalışan cinsiyetinin belirlenen başlıklar üzerinde etkileri ele alınmıştır. Çalışmada doktor ve yardımcı personelin cinsiyetleri konusunda anlamlı fark bulunmuştur $(p=0,040)$. Çalışmaya katılanlar içerisinde erkeklerin \%76,7'si doktor, $\% 23$ 'ü ise yardımcı personeldir. Kadınların \%54,2'si doktor, \%45,8'i yardımcı personeldir. Doktorlarda özellikle cerrahide yer alan çalışanlarda erkek yoğunluğunun olduğu görülmektedir. Yardımcı personel ise çoğunlukla kadınlardan oluşmaktadır. Çalışmaya katılanların yaşlarına bakıldığında kadın ve erkekler arasında anlamlı fark bulunmamıştır $(p=0,544)$. Her iki cinsiyette de çalışanların 20-30 (\%40 erkek, \%37,3 kadın) ve 30-40 (\%30 erkek, \%40,7 kadın) yaşlarında yoğunlukta oldukları görülmüştür. Ameliyathane yoğun çalışma ortamında çalışan yaşlarının genç olması, ortamda çalışma şartlarının ağırlığını ve piramidal bir örgütlenmenin olduğunu da göstermektedir. Çalışmaya katılan kadın ve erkeklerin bulundukları mekânı kullanım süreleri mekânı tanımakta önemli görülmüş ve ameliyathanede çalışma süreleri sorulmuştur. Kadın ve erkeklerin ameliyathanede çalışma sürelerinde anlamlı fark bulunmamıştır $(p=0,552)$ (tablo 7$)$. Kadın ve erkler için ameliyathanede çalışma süreleri, çalışma ortamını değerlendirmede yeterli bir süre olarak görülmektedir. Ameliyathanede çalışan kadın ve erkekler görevli oldukları birimde işlem yaptıkları gibi doktorlar dışındaki personelin farklı intiyaç görülen bölümlerde de çalıştıkları görülmektedir. Ameliyathanede çalışılan bölümde kadın ya da erkek olmanın anlamlı bir fark yaratmadığı görülmüştür $(p=0.053)$ (tablo 8). Ankete katılan erkeler çoğunlukla ortopedi $(\% 40)$ cerrahi biriminde kadınlar $(\% 26,2)$ ise kulak-burun-boğaz cerrahi biriminde çalışmaktadır. Buradaki durumun yapılan cerrahi işlemlerin fiziksel çaba gerektirme durumuna göre birim seçilmesinden kaynaklandığı düşünülmektedir. Her ameliyathane biriminden kişilerin çalışmada yer alması, anket sonuçlarının genelleşmesi için önemlidir.

\begin{tabular}{|c|c|c|c|c|}
\hline & Erkek n(\%) & Kadın n(\%) & Toplam n(\%) & $\mathrm{p}$ \\
\hline 0-1 yıl & $2(\% 10,0)$ & $10(\% 20,4)$ & $12(\% 17,4)$ & 0,552 \\
\hline 1-3 yıl & $5(\% 25,0)$ & $11(\% 22,4)$ & $16(\% 23,2)$ & \\
\hline 4-6 yıl & $6(\% 30,0)$ & $6(\% 12,2)$ & $12(\% 17,4)$ & \\
\hline 6-10 yıl & $3(\% 15,0)$ & $9(\% 18,4)$ & $12(\% 17,4)$ & \\
\hline 10-20 yıl & $2(\% 10,0)$ & $8(\% 16,3)$ & $10(\% 14,5)$ & \\
\hline 20 ve üzeri & $2(\% 10,0)$ & $5(\% 10,2)$ & $7(\% 10,1)$ & \\
\hline TOPLAM & $20 \% 29$ & $49 \% 71$ & 69 (\%100) & \\
\hline
\end{tabular}

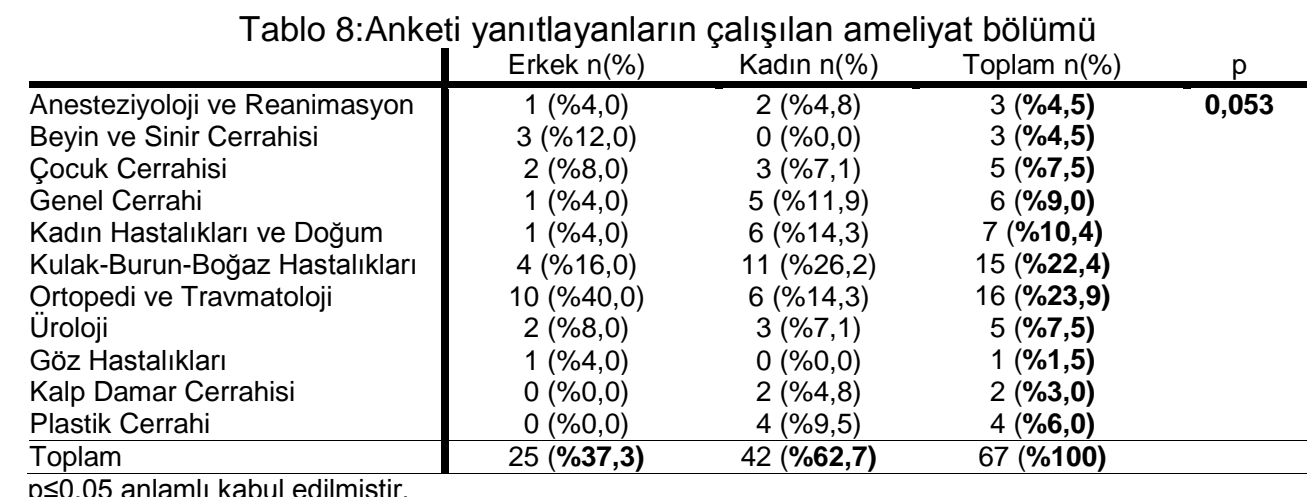

Doktor olan ameliyathane iç kullanıcılarının bulundukları akademik pozisyonda, cinsiyetlerinin kadın ya da erkek olmasında anlamlı fark bulunmamaktadır $(p=0,975)$. Her pozisyondaki erkek ve kadın personelin çalışmaya katılması söz konusudur. Yardımcı personelin de meslekleri cinsiyete göre araştırıımıştır. Yardımcı personelin pozisyonunda cinsiyetin kadın ya da erkek olmasında anlamlı fark bulunmuştur $(p=0,013)$. Kadınların \%66,7'si hemşire iken erkeklerin \%85,7'si büyük çoğunlukla 
teknisyen olarak çalışmaktadır. Burada kadınların ve erkelerin toplumsal meslek belirlemelerine göre seçim yaptıkları açıktır. İç kullanıcıların, ameliyathanelerin kullanıcı açısından durum değerlendirme soruları kullanıcı cinsiyeti açısından ele alınmıştır. Ameliyathane cerrahi odalarının kullanıma uygun boyutlarda olma durumunda kadın ve erkekler arasında anlamlı fark bulunmaktadır $(p=0,005)$ (tablo 9). Erkeler konu üzerinde olumlu (\%43,3 iyi, \%23,3 çok iyi) görüş bildiren kadınlarda (\%32,2 kötü, \%6,8 çok kötü) olumsuz görüş ağırıklıdır. Bunun yanı sıra kadınların \%33,9'u cerrahi odaları kullanıma uygun boyutlandırılmış bulmuşlardır (tablo 9). Cinsiyetin cerrahi birimlerin boyutlandırılmasını algılamada fark yarattığı görülmektedir. Ameliyathane odalarının mahremiyet koruma düzeyi değerlendirmesinde kadın ve erkek personel arasında anlamlı fark bulunmuştur $(\mathrm{p}=0.009)$ (Tablo 9). Erkeler cerrahi odaların mahremiyetini iyi (\%36,7 iyi, \%13,3 çok iyi) bulurken kadın personel kötü (\%33,9 kötü, \%16,9 çok kötü) bulmaktadır. Ayrıca kadınların \%30,5’i ve erkeklerin \%23,3'ü konuda kararsız kalmışlardır (tablo 11). Mahremiyetin görsel ve işitsel olarak sağlanmasında kadın ve erkek personel arasında anlamlı fark vardır $(p=0.009)$ (tablo 9). Görsel ve işitsel mahremiyeti; erkek personelin \%\%43,3'ü (\%33,3 iyi, \%10,0 çok iyi) olumlu bulurken kadın personelin \%612'i (\%40,7 kötü, \%20,3 çok kötü) yetersiz bulmaktadır. Kadın çalışanların \%15,3'ü gibi düşük bir oran ile işitsel ve görsel mahremiyeti olumlu görmektedirler. Ayrıca erkek çalışanların \%33,3 de (\%30,0 kötü, \%3,3 çok kötü) konuda olumsuz görüş bildirmiştir. Kadın $(\% 23,7)$ ve erkeklerde $(\% 23,3)$ kararsız olanların sayısı birbirine yakındır (tablo 9). Ameliyathanede cerrahi kısımlarda ameliyat masası vb cerrahi eşyalar için alanın yeterlilik durumunda kadın ve erkek personel cevapları arasında anlamlı fark yoktur $(\mathrm{p}=0,69)$ (Tablo 9). Kadınların \%33,9'u (iyi $\% 28,8$, çok iyi \%5,1), erkek personelin de \%53,4'ü (iyi \%36,7, çok iyi \%16,7) cerrahi odaların tüm aletler için uygun olduğu yönünde görüş belirtmişlerdir. Kadınların \%47,5'i (kötü \%32,2, çok kötü \%15,3) ve erkeklerin \%23,3'ü ise olumsuz görüş bildirmişlerdir. Kadın ve erkek personelin toplamda \%20,2'si (18 kişi) kararsız kalmışlardır (tablo 9). Ameliyathanede bulunan donanım ile cerrahi oda içerisinde hareket rahatlığı konusunda doktor ve yardımcı personel cevapları arasında anlamlı fark bulunmuştur $(p=0,029)$ (Tablo 11). Erkelerin \%56,6'sı (iyi \%33,3, çok iyi \%23,3), olumlu yönde cevap verirken bu oranın kadın personeldeki durumunda \%32,2 (iyi \%28,8, çok iyi \%3,4) kadınların yarısından biraz fazla bir oran ile olumlu düşündükleri görülmektedir. Kadınların \%45,8'i (kötü \%32,2, çok kötü \%13,3) ve erkek personelin \%26,6'sı (kötü $\% 23,3$, çok kötü \%3,3) ise olumsuz görüş bildirmişlerdir. Burada da, olumlu görüşlerin tam tersi olarak, kadınlar, erkek personelin yarısından biraz fazla orandadır. Kadın ve Erkek personelin toplamda \%20,2'si (18 kişi) kararsız kalmışlardır (tablo 9).

Tablo 9: Ameliyathane odaları kullanıma uygun boyutlandırılması

\begin{tabular}{|c|c|c|c|c|}
\hline & Erkek n(\%) & Kadın n(\%) & Toplam n(\%) & $p$ \\
\hline $\begin{array}{l}\text { Çok kötü } \\
\text { Kötü } \\
\text { Kararsız } \\
\text { İyi } \\
\text { Çok iyi } \\
\text { TOPLAM }\end{array}$ & $\begin{array}{c}2(\% 6,7) \\
5(\% 16,7) \\
3(\% 10,0) \\
13(\% 43,3) \\
7(\% 23,3) \\
30(\% 33,7)\end{array}$ & $\begin{array}{c}4(\% 6,8) \\
19(\% 32,2) \\
15(\% 25,4) \\
20(\% 33,9) \\
1(\% 1,7) \\
59(\% 66,3)\end{array}$ & $\begin{array}{c}6(\% 6,7) \\
24(\% 27,0) \\
18(\% 20,2) \\
33(\% 37,1) \\
8(\% 9,0) \\
8(\% 100)\end{array}$ & 0,005 \\
\hline \multicolumn{5}{|c|}{ Ameliyathane odaları mahremiyeti koruyacak şekilde tasarlanması } \\
\hline $\begin{array}{l}\text { Çok kötü } \\
\text { Kötü } \\
\text { Kararsız } \\
\text { İyi } \\
\text { Çok iyi } \\
\text { TOPLAM }\end{array}$ & $\begin{array}{c}3(\% 10,0) \\
5(\% 16,7) \\
7(\% 23,3) \\
11(\% 36,7) \\
4(\% 13,3) \\
30(\% 33,7)\end{array}$ & $\begin{array}{c}10(\% 16,9) \\
20(\% 33,9) \\
18(\% 30,5) \\
11(\% 18,6) \\
0(\% 0,0) \\
59(\% 66,3)\end{array}$ & $\begin{array}{c}13(\% 14,6) \\
25(\% 28,1) \\
25(\% 28,1) \\
22(\% 24,7) \\
4(\% 4,5) \\
89(\% 100)\end{array}$ & 0,009 \\
\hline \multicolumn{5}{|c|}{ Mahremiyet hem görsel hem işitsel açıdan sağlanması } \\
\hline $\begin{array}{l}\text { Çok kötü } \\
\text { Kötü } \\
\text { Kararsız } \\
\text { İyi } \\
\text { Çok iyi }\end{array}$ & $\begin{array}{c}1(\% 3,3) \\
9(\% 30,0) \\
7(\% 23,3) \\
10(\% 33,3) \\
3(\% 10,0)\end{array}$ & $\begin{array}{c}12(\% 20,3) \\
24(\% 40,7) \\
14(\% 23,7) \\
9(\% 15,3) \\
0(\% 0,0)\end{array}$ & $\begin{array}{c}13(\% 14,6) \\
33(\% 37,1) \\
21(\% 23,6) \\
19(\% 21,3) \\
3(\% 3,4)\end{array}$ & 0,009 \\
\hline
\end{tabular}




\begin{tabular}{|c|c|c|c|c|}
\hline TOPLAM & $30(\% 33,7)$ & $59(\% 66,3)$ & $89(\% 100)$ & \\
\hline \multicolumn{5}{|c|}{ Ameliyat masası ve diğer eşyalar için yeterli alan olması } \\
\hline $\begin{array}{l}\text { Çok kötü } \\
\text { Kötü } \\
\text { Kararsız } \\
\text { İyi } \\
\text { Çok iyi } \\
\text { TOPLAM }\end{array}$ & $\begin{array}{c}0(\% 0,0) \\
7(\% 23,3) \\
7(\% 23,3) \\
11(\% 36,7) \\
5(\% 16,7) \\
30(\% 33,7)\end{array}$ & $\begin{array}{c}9(\% 15,3) \\
19(\% 32,2) \\
11(\% 18,6) \\
17(\% 28,8) \\
3(\% 5,1) \\
59(\% 66,3)\end{array}$ & $\begin{array}{c}9(\% 10,1) \\
26(\% 29,2) \\
18(\% 20,2) \\
28(\% 31,5) \\
8(\% 9,0) \\
89(\% 100)\end{array}$ & 0,69 \\
\hline \multicolumn{5}{|c|}{ Ameliyathane teçhizatı ile oda içinde rahatça hareket etmesi } \\
\hline $\begin{array}{l}\text { Çok kötü } \\
\text { Kötü } \\
\text { Kararsız } \\
\text { İyi } \\
\text { Çok iyi } \\
\text { TOPLAM }\end{array}$ & $\begin{array}{c}1(\% 3,3) \\
7(\% 23,3) \\
5(\% 16,7) \\
10(\% 33,3) \\
7(\% 23,3) \\
30(\% 33,7)\end{array}$ & $\begin{array}{c}8(\% 13,6) \\
19(\% 32,2) \\
13(\% 22,0) \\
17(\% 28,8) \\
2(\% 3,4) \\
59(\% 66,3)\end{array}$ & $\begin{array}{c}9(\% 10,1) \\
26(\% 29,2) \\
18(\% 20,2) \\
27(\% 30,3) \\
9(\% 10,1) \\
89(\% 100)\end{array}$ & 0,029 \\
\hline
\end{tabular}

Ameliyathanede kullanılan teçhizatın uygun olup olmadığı konusunda kadın ve erkek çalışan cevapları arasında anlamlı fark bulunmuştur $(p=0,044)$ (Tablo 10). Erkelerin $\% 76,7$ 'si (iyi \%66,7, çok iyi \%10), olumlu yönde cevap verirken bu oranın kadın personeldeki durumda; $\% 42,4$ 'ü (iyi $\% 37,3$, çok iyi $\% 5,1$ ) oranında olumlu düşündükleri görülmektedir. Erkeklerin \%3,3'ü ve kadınların \%15,5'i (kötü \%13,6, çok kötü \%1,7) ise olumsuz görüş bildirmişlerdir. Burada da, olumlu görüşlerin tam tersi olarak, erkelerin kadın çalışanların cevaplarının çok altında bir oranda oldukları görülmektedir. Kadın ve erkek personelin toplamda \%34,8'i (31 kişi) kararsız kalmışlardır (tablo 12). Cerrahi birimlere girmeden önce yıkama/fırçalama (sterilizasyon) gibi işlemlerin yapıldığı alanın kullanıma uygunluğuna verilen yanıtlarda kadın ve erkek personel cevapları arasında anlamlı fark yoktur $(p=0,433$ ) (Tablo 10). Kadın personelin \%33,9'u (iyi \%30,5, çok iyi $\% 3,4$ ), erkek personelin de \%53,3'ü (iyi \%43,3, çok iyi \%10) yıkama/fırçalama, sterilizasyon alanlarının uygun olduğu yönünde görüş belirtmişlerdir. Kadınların \%30,8'i (kötü \%22, çok kötü \%8,5) ve erkek personelin \%23,4'ü (kötü \%16,7, çok kötü \%6,7) olumsuz görüş bildirmişlerdir. Kadın ve erkek personelin toplamda \%31,5'inin (28 kişi) kararsız kaldıkları görülmüştür (tablo 10). Cerrahi birimin, kadın ve erkek personel tarafından kullanımının rahatlığına verilen yanıtlarda personelin cevapları arasında anlamlı fark yoktur ( $p=0,154)$ (Tablo 10). Kadınların \%25,4'ü (iyi \%20,3, çok iyi \%5,1) ve erkek personelin \%46,7'si (iyi \%36,7, çok iyi \%10) cerrahi birimin kullanım rahatlığına sahip olduğu olduğunu belirtmişlerdir. Kadın personelin \%35,6'sı (kötü $\% 30,5$, çok kötü $\% 5,1$ ), erkek personelin $\% 13,3$ 'ü ise olumsuz görüş bildirmişlerdir. Konuda kararsız olanların oranı ise toplamda \%39,3'dür (35 kişi) (tablo10). Araştırmada engelli kişilerin durumu da sorgulanmaya çalışılmıştır. Buna göre Cerrahi alanların engelli bireylere uygunluğuna yönelik yanıtlarda kadın ve erkek personel cevapları arasında anlamlı fark bulunmamıştır $(p=0,301)$ (Tablo 10). Erkeklerin \%30,0'u (iyi \%23,3, çok iyi \%6,7), kadın personelin de \%17,0'si (iyi \%15,3, çok iyi \%1,7) cerrahi alanları engelli kişiler (hasta ve personel) için kullanıma uygun olduğunu belirtmişlerdir. Bu düşük bir orandır. erkeklerin \%36,6'sı (kötü \%23,3, çok kötü \%13,3) ve kadın personelin \%57,6'sı (kötü \%28,8, çok kötü \%28,8), konuda, olumsuz görüş bildirmişlerdir. Toplamda \%28,1 (25 kişi) ise kararsız kalmıştır (tablo 10). Engelli kişiler için herhangi bir uygulama yapılmadığı görülmektedir.

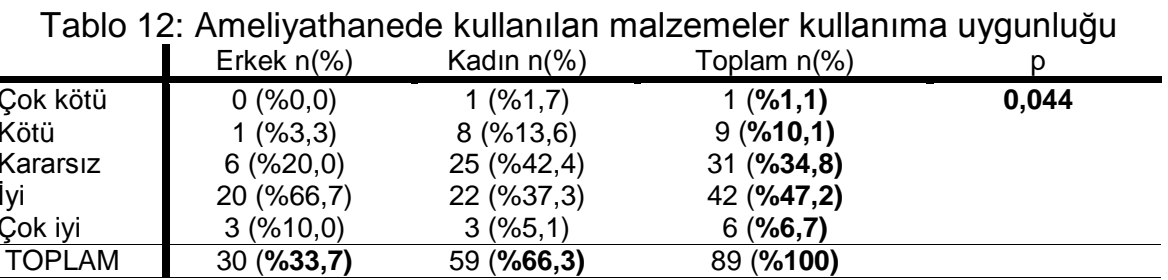

Ameliyathane odalarına giriş ünitesi (sterilizasyon gibi) kullanıma uygun tasarlanması

\begin{tabular}{l|cccc}
\hline Çok kötü & $2(\% 6,7)$ & $5(\% 8,5)$ & $7(\% 7,9)$ & $\mathbf{0 , 4 3 3}$
\end{tabular}




\begin{tabular}{|c|c|c|c|c|}
\hline & & & & \\
\hline Kötü & $5(\% 16,7)$ & $13(\% 22,0)$ & $18(\% 20,2)$ & \\
\hline Kararsız & $7(\% 23,3)$ & $21(\% 35,6)$ & $28(\% 31,5)$ & \\
\hline & $13(\% 43,3)$ & $18(\% 30,5)$ & $31(\% 34,8)$ & \\
\hline Çok iyi & $3(\% 10,0)$ & $2(\% 3,4)$ & $5(\% 5,6)$ & \\
\hline TOPLAM & $30(\% 33,7)$ & $59(\% 66,3)$ & 89 (\%100) & \\
\hline \multicolumn{5}{|c|}{ Ameliyathane odasının herkes tarafından kolay kullanımı düşünülmesi } \\
\hline Çok kötü & $0(\% 0,0)$ & $3(\% 5,1)$ & $3(\% 3,4)$ & 0,154 \\
\hline Kötü & $4(\% 13,3)$ & $18(\% 30,5)$ & $22(\% 24,7)$ & \\
\hline Kararsız & $12(\% 40,0)$ & $23(\% 39,0)$ & $35(\% 39,3)$ & \\
\hline İyi & $11(\% 36,7)$ & $12(\% 20,3)$ & $23(\% 25,8)$ & \\
\hline Çok iyi & $3(\% 10,0)$ & $3(\% 5,1)$ & $6(\% 6,7)$ & \\
\hline TOPLAM & $30(\% 33,7)$ & $59(\% 66,3)$ & 89 (\%100) & \\
\hline \multicolumn{5}{|c|}{ Ameliyathane odaları engelliler için uygun tasarlanması } \\
\hline Çok kötü & $4(\% 13,3)$ & $17(\% 28,8)$ & $21 \%(23,6)$ & 0,301 \\
\hline Kötü & $7(\% 23,3)$ & $17(\% 28,8)$ & $24 \%(27,0)$ & \\
\hline Kararsız & $10(\% 33,3)$ & $15(\% 25,4)$ & $25 \%(28,1)$ & \\
\hline & $7(\% 23,3)$ & $9(\% 15,3)$ & $16 \%(\mathbf{1 8 , 0 )}$ & \\
\hline Çok iyi & $2(\% 6,7)$ & $1(\% 1,7)$ & $3 \%(3,4)$ & \\
\hline TOPLAM & $30(\% 33,7)$ & $59(\% 66,3)$ & 89 (\%100) & \\
\hline
\end{tabular}

Ameliyathanede genel tüm odaların gün ışığı alma durumuna verilen yanıtlarda kadın ve erkek personel cevapları arasında anlamlı fark bulunmamıştır $(p=0,285)$ (Tablo 11). Erkeklerin \%10,0'u (iyi \%3,3, çok iyi \%6,7), kadın personelin ise \%5,3'ü (iyi \%5,3) gün ışığının alınmasını olumlu görmektedir. Bu oran çok düşüktür. Erkeklerin \%83,3'ü (kötü $\% 13,3$, çok kötü \%70,0), kadın personelin ise \%81,3'ü (kötü \%18,4, çok kötü \%70,1), ise yeterli gün ışığının alınmadığını bildirmişlerdir. Kadın ve erkek personelin toplamda \%4,6'sı (4 kişi) ise görüş bildirmemiştir (tablo 11). Ameliyathanenin kesinlikle yeterli gün ışığı almadığı her iki cinsiyet tarafından verilen cevaplarda görülmektedir. Ameliyathanede genel tüm odaların manzara ve dış alanlara bakma durumuna verilen yanıtlarda kadın ve erkek personel cevaplarında anlamlı fark bulunmamıştır $(p=0,250)$ (Tablo 11). Kadın personelin \%1,8'i, erkek personelin de \%6,7'si dış alanlara bakan mekânlar konusunda olumlu görüş bildirmiştir. Doktor ofisleri, dinlenme alanları da dâhil olmak üzere yeterli bir şekilde dış alan ile bağlantı olmadığı her iki cinsiyet için de açıktır. Kadın personelin \%93'ü (kötü \%15,8, çok kötü \%77,2) ve erkek personelin \%90,0'ı (kötü \%23,3, çok kötü \%66,7) yeterli dış alanlar ile bağlantı olmadığını bildirmişlerdir (tablo 11). Dış alanlar ile olan görsel bağın kurulması kadın ve erkek personel için önemli bir konudur. Yoğun çalışılan ortamda dinlenme alanları için dış ortam ile görsel bağın düşünülmesi çalışan sağlığı açısından da önemli bir konudur. Ameliyathane iç mekân tasarımının çalışanlar üzerindeki etkisinde kadın ve erkek personel cevapları arasında anlamlı fark bulunmamıştır $(p=0,081)$ (Tablo 11). Kadın personelin \%15,5'i (iyi \%15,5) ve erkek personelin \%16,'7'si (iyi \%10,0, çok iyi \%6,7) yani düşük oranlar ile olumlu görürlerken, kadınların \%55,2'si (kötü \%27,6, çok kötü $\% 27,6$ ) ve erkelerin \%66'7'si (kötü \%46,7 çok kötü \%20,0), konuda, olumsuz görüş bildirmişlerdir. Toplamda \%25 (22 kişi) ise kararsız kalmıştır (tablo 11). Her iki cinsiyet için de iç mekân tasarımı çoğunlukla olumsuz olması, konu üzerinde eğilmesi gerektiğinin göstergesidir. Ameliyathanede belirlenen genel tüm odaların renklerinin durumu, sıcak (kırmızı, turuncu, sarı), soğuk (mavi, yeşil), nötr (beyaz ve tonları) olmasına verilen yanıtlarda kadın ve erkek personel cevapları arasında anlamlı fark bulunmamıştır ( $p=0,511$ ) (Tablo 11). Erkelerin \%12,0'si (3 kişi) ve kadın personelin $\% 10,5$ 'i (6 kişi) ameliyathane renklerini sıcak olarak nitelendirilirken, erkeklerin \%44,0"ü (11 kişi) ve kadınların \%42,1'i (24 kişi) soğuk renkler olarak nitelendirmiştir. Ayrıca çalışmada erkelerin \%44,0'ü (11 kişi) ve kadınların \%47,4'ü (27 kişi) ise ameliyathane renklerini nötr olarak yorumlamışlardır (tablo 11). Yerinde yapılan tespitlerde de nötr ve soğuk renk kullanımının olduğu görülmektedir. Ameliyathanede kullanılan malzemelerin (mobilya yatak vb. cerrahi için gerekli donanım) yüzey kaplamalarının pürüzsüz, hijyenik, kolay temizlenir ve estetik kaygıları olan malzemelerden olması durumuna verilen yanıtlarda kadın ve erkek personel cevapları arasında anlamlı fark 
bulunmamıştır $(p=0,073)$ (Tablo 11). Erkek personelin \%60,0'ı (15 kişi) ve kadın personelin \%62,5'i (25 kişi) pürüzsüz hijyenik olması gerek derken, erkelerin \%28,0'i (7 kişi) ve kadınların \%37,5’i (15 kişi) kolay temizlenir olmasının önemli olduğunu belirtmişlerdir. Erkek personelin \%12,0'si (3 kişi) ise estetik kaygıları da olması gerekliliği söylemektedir (tablo 13). Kadın personelden beklenen estetik kaygılara yönelik cevabın erkeklerden az sayıda da olsa erkeklerden gelmiş olması ilginçtir. Ameliyathane cerrahi odalarda ve diğer odalarda estetik ögelerin yeterli ve doğru kullanımına verilen yanıtlarda kadın ve erkek personel cevapları arasında anlamlı fark bulunmamıştır ( $p=0,280$ ) (Tablo 11). Erkelerin \%17,2'si (iyi \%13,7, çok iyi \%3,4) ve kadınların \%8,5'i (iyi \%8,5) düşük oranlar ile olumlu yorumlamaktadırlar. Erkelerin \%41,3'ü (kötü \%24,1, çok kötü \%17,2) ve kadınların \%62,7'si (kötü \%35,6, çok kötü $\% 27,1$ ), ise olumsuz görüş bildirmişlerdir. Toplamda personelin \%33'ü (29 kişi) ise kararsız kalmıştır (tablo 11). Ameliyathanede kullanılan estetik ögelerin doğru ve yeterli kullanım kaygıları düşünülerek seçilmediği işlevsel kaygıların ön planda olduğu açıktır. Her iki cinsiyet de durumu doğrulamaktadır. Ameliyathane genelinde malzeme seçimlerinin estetik olup olmamasına yönelik verilen yanıtlarda kadın ve erkek personel cevapları arasında anlamlı fark bulunmamıştır $(p=0,147)$ (Tablo 11). Erkeklerin \%13,8'i (iyi $\% 13,8$ ) ve kadınların $\% 10,3$ 'ü (iyi $\% 8,6$, çok iyi $\% 1,7$ ) gibi düşük oranlar ile olumlu yanıtlar vermişlerdir. Malzeme seçiminin estetik olmasına erkelerin \%37,9'u (kötü $\% 17,2$, çok kötü \%20,7) ve kadınların \%63,8'i (kötü \%37,9, çok kötü \%25,9), olumsuz görüş bildirmişlerdir. Tüm personelin \%33,3'ü (29 kişi) ise kararsız kalmıştır (tablo 11). Ameliyathanede kullanılan malzemelerin estetik düşünülerek seçilmediği işlevsel kaygıların ön planda olduğu kadın ve erkek personelce kabul edilmektedir.

Tablo 11: Ameliyathane odalarında gün ışığının yeterince içeri alınması

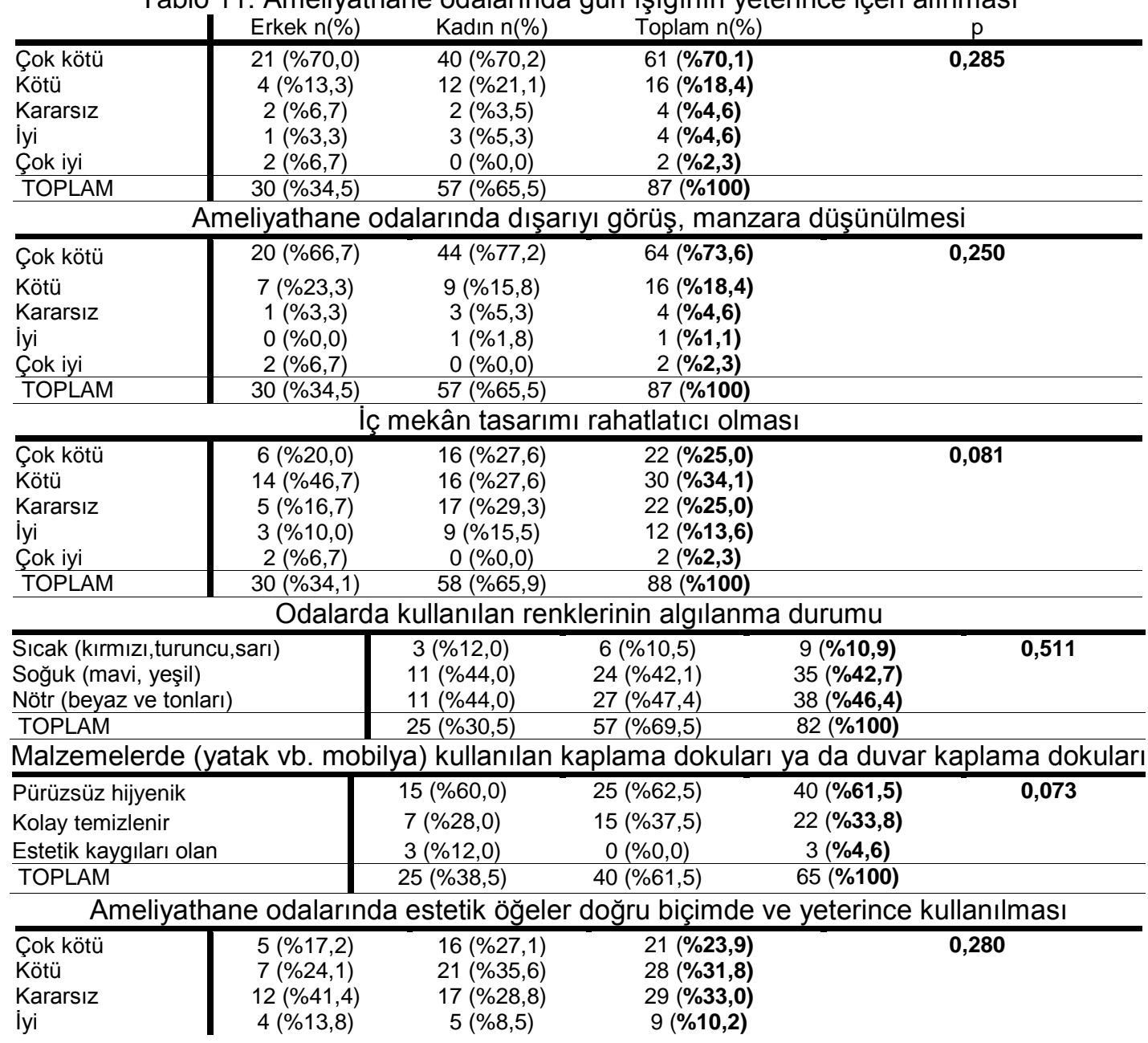


Ameliyathane Performanslarının İç Kullanıcı Memnuniyeti Açısından İncelenmesi; Erciyes Üniversitesi Gevher Nesibe Hastanesi Örneği Investigation of Operating Room Performances in Terms of Internal User Satisfaction; an Example of a University Hospital

\begin{tabular}{|c|c|c|c|c|}
\hline Çok iyi & $1(\% 3,4)$ & $0(\% 0,0)$ & $1(\% 1,1)$ & \\
\hline TOPLAM & $29(\% 33,0)$ & $59(\% 67,0)$ & $88(\% 100)$ & \\
\hline \multicolumn{5}{|c|}{ Malzeme seçiminin estetik algısı } \\
\hline Çok kötü & $6(\% 20,7)$ & $15(\% 25,9)$ & $21(\% 24,1)$ & 0,147 \\
\hline Kötü & $5(\% 17,2)$ & $22(\% 37,9)$ & $27(\% 31,0)$ & \\
\hline Kararsız & $14(\% 48,3)$ & $15(\% 25,9)$ & $29(\% 33,3)$ & \\
\hline İyi & $4(\% 13,8)$ & $5(\% 8,6)$ & $9(\% 10,3)$ & \\
\hline Çok iyi & $0(\% 0,0)$ & $1(\% 1,7)$ & $1(\% 1,1)$ & \\
\hline TOPLAM & $29(\% 33,3)$ & $58(\% 66,7)$ & 87 (\%100) & \\
\hline
\end{tabular}

Ameliyathane iç ortam ısısal konforuna verilen cevaplarda erkek ve kadın personel cevaplarında anlamlı fark bulunmuştur $(p=0,038)$ (Tablo 12). Erkelerin \%56,7'si (iyi $\% 30,0$, çok iyi \%26,7), kadınların da \%30,5’i (iyi \%23,7, çok iyi \%6,8) ısısal konforu olumlu olarak belirtmişlerdir. Erkeklerin \%23,3'ü (kötü \%20,0, çok kötü \%3,3) ve kadınların \%42,3'ü (kötü \%23,7, çok kötü \%18,6) yeterli ısısal konforun olmadığını bildirmişlerdir (tablo 12). İş yerlerinde ısısal ölçümlerin yapılması önemli bir konudur. Cinsiyetin ortam ısısını algı konusunda farklılıklar olabileceği düşünülmektedir. Erkeler ve kadınlar arasındaki bu farkın çıkmasına yönelik araştırmaların yapılması önemlidir. Çalışanların çalışma ortamı ölçümlerinde cinsiyetleri de ön planda tutulmalıdır. Ameliyathanede rahatsız edici kokulara yönelik önlem alınıp alınmadığı sorularak ameliyathanenin iç ortam hava kalitesinin durumu ele alınmıştır. Kadın ve Erkek personel cevaplarında anlamlı fark bulunmuştur $(p=0,038)$ (Tablo 12). Erkek personelin $\% 46,7$ 'si (iyi \%30,0, çok iyi \%16,7), kadın personelin ise \%23,7'si (iyi \%22,0, çok iyi $\% 1,7)$ rahatsız edici kokulara karşı önlemde olumlu görüş belirtmişlerdir. Erkelerin $\% 27,3$ 'ü (kötü \%16,7, çok kötü \%10,0), kadınların ise \%49,1'i (kötü \%22,0, çok kötü $\% 27,1)$ rahatsız edici kokulara karşı önlem olmadığını bildirmişlerdir (tablo 14). Ayrıca \%27 (24 kişi) karasızdır. Erkek personel iç ortam hava kalitesinin iyi olduğunu düşünürken kadın personelin tersi yönde düşündüğü görülmektedir. Yine çalışma ortam iç hava kalitesi ölçümlerinin yapılması gerekmektedir. Ayrıca kadın ve erkelerin duyarlılık düzeyleri de ölçümler sırasında göz önünde bulundurulmalıdır. Çalışma ortamına yönelik diğer soru ise ameliyathanenin yapay aydınlatma durumu irdeleneceği aydınlatma, parlama ve göz almaya yönelik tasarımları irdelemek için hazırlanmıştır. Alınan cevaplarda kadın ve erkek personel arasında anlamlı fark bulunmamıştır $(p=0,757)$ (Tablo 12). Erkeklerin \%46,7'si (iyi \%40,0, çok iyi \%6,7), kadınların da $\% 39,0$ 'u (iyi \%35,6, çok iyi \%3,4) yapay aydınlatmanın iyi olduğunu söylemektedir.. Erkek personelin \%30'u (kötü \%23,3, çok kötü \%6,7), kadın personelin ise \%35,6'sı (kötü \%20,3, çok kötü \%15,3) yapay aydınlatma konusunda olumsuz görüş bildirmiştir (tablo 14). Toplam personelin \%24,7'si (22 kişi) ise karasızdır. Ameliyathanenin iç ortam yapay havalandırma durumu için odaların yapay havalandırması sorgulanmıştır. Konuya verilen cevaplarda kadın ve erkek personel cevaplarında anlamlı fark bulunmamıştır $(p=0,285)$ (Tablo 12). Erkelerin \%56,7'si (iyi \%40,0, çok iyi \%16,7), kadınların \%35,6'sı (iyi \%28,8, çok iyi \%6,8) yapay havalandırmanın iyi olduğunu söylemektedir. Erkelerin \%20'si (kötü \%13,3, çok kötü \%6,7), kadınların ise \%35,5'i (kötü \%16,9, çok kötü \%18,6) yapay havalandırmanın yeterli olmadığını bildirmişlerdir (tablo 14). Toplamda \%27 (24 kişi) ise karasızdır. Genel olarak iç ortam yapay havalandırmanın iyi olduğu görülmektedir. Yine de çalışma ortamı ölçümlerinin periyodik yapılması önemlidir. Ameliyathanede ses izolasyon durumu da irdelenmesi gerek bir konudur. Konuya verilen cevaplarda doktor ve yardımcı personel cevaplarında anlamlı fark bulunmamaktadır $(p=0,468)$ (Tablo 12). Doktorların \%10,9'u (iyi $\% 9,1$, çok iyi \%1,8) ve yardımcı personelin \%20,6'sı (iyi \%14,7, çok iyi \%2,9) ses yalıtımının iyi olduğunu belirtmişlerdir. Burada oran çok her iki çalışan kesimi için de düşüktür. Doktorların \%63,7'si (kötü \%38,2, çok kötü \%25,5) ve yardımcı personelin \%61,8'i (kötü \%41,2, çok kötü \%20,6) ses izolasyonunun yeterli olmadığını bildirmişlerdir (tablo 12). Toplamda \%23,6 (21 kişi) karasızdır. Hasta ve çalışanların 
konforları düşünüldüğünde ses izolasyonunun her iki kesim için de iyi olması gereklidir. Ameliyathanenin bu konuda yetersiz olduğu açıktır.

\begin{tabular}{|c|c|c|c|c|}
\hline & Erkek $\mathrm{n}(\%)$ & Kadın n(\%) & Toplam n(\%) & $\mathrm{p}$ \\
\hline $\begin{array}{l}\text { Çok kötü } \\
\text { Kötü }\end{array}$ & $\begin{array}{c}1(\% 3,3) \\
6(\% 20,0)\end{array}$ & $\begin{array}{l}11(\% 18,6) \\
14(\% 23,7)\end{array}$ & $\begin{array}{l}12(\% 13,5) \\
20(\% 22,5)\end{array}$ & 0,038 \\
\hline $\begin{array}{l}\text { Kararsız } \\
\text { İyi } \\
\text { Çok iyi } \\
\text { TOPLAM }\end{array}$ & $\begin{array}{c}6(\% 20,0) \\
9(\% 30,0) \\
8(\% 26,7) \\
30(\% 33,7)\end{array}$ & $\begin{array}{c}16(\% 27,1) \\
14(\% 23,7) \\
4(\% 6,8) \\
59(\% 66,3)\end{array}$ & $\begin{array}{l}22(\% 24,7) \\
23(\% 25,8) \\
12(\% 13,5) \\
89(\% 100)\end{array}$ & \\
\hline \multicolumn{5}{|c|}{ Ameliyathane odalarında rahatsız edici kokulara karşı önlem alma } \\
\hline
\end{tabular}

Ameliyathane ışıklandırma, gereksiz parlama ve göz alıcılığı önleyecek şekilde doğru tasarlanması

\begin{tabular}{|c|c|c|c|c|}
\hline \\
\hline Çok kötü & $2(\% 6,7)$ & $9(\% 15,3)$ & $11(\% 12,4)$ & 0,757 \\
\hline Kötü & $7(\% 23,3)$ & $12(\% 20,3)$ & $19(\% 21,3)$ & \\
\hline Kararsız & $7(\% 23,3)$ & $15(\% 25,4)$ & $22(\% 24,7)$ & \\
\hline İyi & $12(\% 40,0)$ & $21(\% 35,6)$ & $33(\% 37,1)$ & \\
\hline Çok iyi & $2(\% 6,7)$ & $2(\% 3,4)$ & $4(\% 4,5)$ & \\
\hline TOPLAM & $30(\% 33,7)$ & $59(\% 66,3)$ & $89(\% 100)$ & \\
\hline \multicolumn{5}{|c|}{ Ameliyathane odalarının havalandırması iyi yapılması } \\
\hline Çok kötü & $2(\% 6,7)$ & $11(\% 18,6)$ & $13(\% 14,6)$ & 0,285 \\
\hline Kötü & $4(\% 13,3)$ & $10(\% 16,9)$ & $14(\% 15,7)$ & \\
\hline Kararsız & $7(\% 23,3)$ & $17(\% 28,8)$ & $24(\% 27,0)$ & \\
\hline İyi & $12(\% 40,0)$ & $17(\% 28,8)$ & $29(\% 32,6)$ & \\
\hline Çok iyi & $5(\% 16,7)$ & $4(\% 6,8)$ & $9(\% 10,1)$ & \\
\hline TOPLAM & $30(\% 33,7)$ & $59(\% 66,3)$ & 89 (\%100) & \\
\hline \multicolumn{5}{|c|}{ Ameliyathane odaları ses açısından izole edilmesi } \\
\hline Çok kötü & $5(\% 16,7)$ & $16(\% 27,1)$ & $21(\% 23,6)$ & 0,468 \\
\hline Kötü & $10(\% 33,3)$ & $25(\% 42,4)$ & $35(\% 39,3)$ & \\
\hline Kararsız & $10(\% 33,3)$ & $11(\% 18,6)$ & $21(\% 23,6)$ & \\
\hline İyi & $4(\% 13,3)$ & $6(\% 10,2)$ & $10(\% 11,2)$ & \\
\hline Çok iyi & $1(\% 3,3)$ & $1(\% 1,7)$ & $2(\% 2,2)$ & \\
\hline TOPLAM & $30(\% 33,7)$ & $59(\% 66,3)$ & $89(\% 100)$ & \\
\hline
\end{tabular}

Ameliyathanede hastaların giriş kısmının gerçekleştiği alanda hastalar ve refakatçilerin bulunduğu alanların refakatçiler için düzenleme durumuna verilen cevaplarda kadın ve erkek personel arasında anlamlı fark bulunmamaktadır $(p=0,531)$ (Tablo 13). Erkek personelin \%13,3'ü (iyi \%13,3) ve kadın personelin \%8,9'u (iyi \%7,1, çok iyi \%1,8) refakatçiler için düzenleme yapıldığını belirtirken erkelerin \%56,7'si (kötü \%30,0, çok kötü \%26,7) ve kadınların \%58,9'u (kötü \%19,6, çok kötü \%39,3) refakatçiler için yapılan düzenlemelerin yetersiz olduğunu bildirmişlerdir (tablo 15). Kararsız kalanların oranı ise \%31,4'dür (27 kişi). Refakatçilerin de olması gerektiği durumlar için olan alanın yetersizliğini her iki cinsiyet de belirlemiştir. Ameliyathane koridorları, bekleme alanları, hasta bekleme alanları gibi yerlerinde estetik ögelerin kullanılma durumuna verilen yanıtlarda kadın ve erkek personel cevapları arasında anlamlı fark bulunmuştur $(p=0,028)$ (Tablo 13). Erkeklerin \%10,3'ü (iyi \%3,4, çok iyi \%6,9) ve kadınların \%17,2'si (iyi \%17,2) gibi düşük oranlar ile estetik ögelerin kullanımını olumlu görmektedirler. Erkelerin \%54,5'i (kötü \%34,5, çok kötü \%20,7) ve kadınların \%67,2'si (kötü \%36,2, çok kötü \%31,0), konuda, olumsuz görüş bildirmişlerdir. Burada her iki grup için olumsuz mekân algısı kuvvetlidir. Konu üzerindeki fark, karasız kalan erkek $(\% 34,5)$ ve kadın $(\% 15,5)$ personel arasında oluşmaktadır (tablo 13). Bu durum cinsiyetlerin estetik ögelere bakıştaki kararsızlığını belirleme açısından ilginçtir. Ameliyathanede belirtilen 
alanlarda estetik ögelerin kullanımı olmadığı görülmektedir. Hijyen kurallarının nasıl işleyeceği ve işlevsel kaygılar konunun iki ana sebebi olarak görülmektedir.

Tablo 13: Ameliyathanede refakatçiler için gerekli düzenlemeler yapılması

\begin{tabular}{|c|c|c|c|c|}
\hline & Erkek n(\%) & Kadın $n(\%)$ & Toplam n(\%) & $\mathrm{p}$ \\
\hline $\begin{array}{l}\text { Çok kötü } \\
\text { Kötü } \\
\text { Kararsız } \\
\text { lyi } \\
\text { Çok iyi }\end{array}$ & $\begin{array}{c}8(\% 26,7) \\
9(\% 30,0) \\
9(\% 30,0) \\
4(\% 13,3) \\
0(\% 0,0)\end{array}$ & $\begin{array}{c}22(\% 39,3) \\
11(\% 19,6) \\
18(\% 32,1) \\
4(\% 7,1) \\
1(\% 1,8)\end{array}$ & $\begin{array}{c}30(\% 34,9) \\
20(\% 23,3) \\
27(\% 31,4) \\
8(\% 9,3) \\
1(\% 1,2) \\
\end{array}$ & 0,531 \\
\hline TOPLAM & $30(\% 34,9)$ & $56(\% 65,1)$ & $86(\% 100)$ & \\
\hline \multicolumn{5}{|c|}{ Ameliyathanede odalarının dolaşım alanında estetik öğeler kullanılması } \\
\hline $\begin{array}{l}\text { Çok kötü } \\
\text { Kötü } \\
\text { Kararsız } \\
\text { lyi } \\
\text { Çok iyi }\end{array}$ & $\begin{array}{c}6(\% 20,7) \\
10(\% 34,5) \\
10(\% 34,5) \\
1(\% 3,4) \\
2(\% 6,9)\end{array}$ & $\begin{array}{c}18(\% 31,0) \\
21(\% 36,2) \\
9(\% 15,5) \\
10(\% 17,2) \\
0(\% 0,0)\end{array}$ & $\begin{array}{c}24(\% 27,6) \\
31(\% 35,6) \\
19(\% 21,8) \\
11(\% 12,6) \\
2(\% 2,3)\end{array}$ & 0,028 \\
\hline TOPLAM & $29(\% 33,3)$ & $58(\% 66,7)$ & 87 (\%100) & \\
\hline
\end{tabular}

Ameliyathane ortamında çalışanların güvenliğinin sorgulandığı ve çalışma ortamında düşmeler ile ilgili soruda erkek ve kadın personel arasında anlamlı fark bulunamamıştır $(p=0,500)$. Erkeklerin \%33,3'ü düşme olayı ile karşılaşırken kadınların \%40,7'si düştüklerini belirtmişlerdir (Tablo 14). Erkek ve kadın personelin çoğunluğu (\%78) ise düşme olayı yaşamamıştır. Yinede düşme sebepleri araştırılarak gerekli önlem alınması söz konusudur. Ayrıca farklı güvenlik problemleri yaşama durumunda erkek ve kadın personel arasında anlamlı fark bulunamamıştır $(p=0,536)$ (Tablo 14). Erkelerin $\% 17,9$ 'u ve kadınların \%23,7'si farklı güvenlik problemleri ile karşılaşırken erkeklerin $\% 82,1$ 'i ve kadınların \%76,3'ü hiç bir güvenlik problem yaşamadıklarını belirtmiştir (Tablo 14). Az sayıda da olsa yaşanan güvenlik problemlerinin sebebi araştırılarak mekâna ve malzemeye yönelik olanların çözülmesi önemlidir. ancak yapılan yüz yüze görüşmelerden anlaşılan mekân ya da malzemeye yönelik olmadığı yönündedir. Ameliyathanede kadın ve erkek personelin mekândan beklentilerinin durumu, mekân oluşturmada katkısı olarak görülmüştür. İşlev, güvenlik, estetik, rahatlık ve mahremiyet konularından hangisinin ilk sırada olduğu belirlenmeye verilen cevaplarda kadın ve erkek personel arasında anlamlı fark bulunmamıştır $(p=0,912)$ (Tablo 14). Erkek ve kadın personel cevaplarında ilk sırayı işlev (Erkek \%53,6, \%49,1), ikinci güvenlik (Erkek \%21,4, Kadın \%30,9) almaktadır. Sonrasında rahatlık ve mahremiyet önemli görülürken estetik son sırada yer almıştır. Her iki cinsiyet için ameliyathaneden beklentilerde mekânın kullanım amacına uygun bir sonuç ortaya çıkmıştır.

Tablo 14: Ameliyathanede odalarında düşme yaşanması

\begin{tabular}{|c|c|c|c|c|}
\hline & Erkek n(\%) & Kadın $\mathrm{n}(\%)$ & Toplam n(\%) & $\mathrm{p}$ \\
\hline $\begin{array}{l}\text { Evet } \\
\text { Hayır }\end{array}$ & $\begin{array}{l}10(\% 33,3) \\
20(\% 66,7)\end{array}$ & $\begin{array}{l}24(\% 40,7) \\
35(\% 59,3)\end{array}$ & $\begin{array}{l}34(\% 38,2) \\
55(\% 61,8)\end{array}$ & 0,500 \\
\hline TOPLAM & $30(\% 33,7)$ & $59(\% 66,3)$ & 89 (\%100) & \\
\hline \multicolumn{5}{|c|}{ Ameliyathanede odalarında güvenlikle ilgili başka sıkıntıların olması } \\
\hline $\begin{array}{l}\text { Evet } \\
\text { Hayır }\end{array}$ & $\begin{array}{c}5(\% 17,9) \\
23(\% 82,1)\end{array}$ & $\begin{array}{l}14(\% 23,7) \\
45(\% 76,3)\end{array}$ & $\begin{array}{l}19(\% 21,8) \\
68(\% 78,2)\end{array}$ & 0,536 \\
\hline TOPLAM & $28(\% 32,2)$ & $59(\% 67,8)$ & 87 (\%100) & \\
\hline \multicolumn{5}{|c|}{ Ameliyathanede odasından beklentilerin önem sırasına göre sıralanmas } \\
\hline İșev & $15(\% 53,6)$ & $27(\% 49,1)$ & $42(\% 50,6)$ & 0,912 \\
\hline Güvenlik & $6(\% 21,4)$ & $17(\% 30,9)$ & $23(\% 27,7)$ & \\
\hline Estetik & $1(\% 3,6)$ & $2(\% 3,6)$ & $3(\% 3,6)$ & \\
\hline Rahatlık & $3(\% 10,7)$ & $5(\% 9,1)$ & $8(\% 9,6)$ & \\
\hline Mahremiyet & $3(\% 10,7)$ & $4(\% 7,3)$ & $7(\% 8,4)$ & \\
\hline TOPLAM & $28(\% 33,7)$ & $55(\% 66,3)$ & $83(\% 100)$ & \\
\hline
\end{tabular}

$p \leq 0.05$ anlamlı kabul edilmiştir. 


\section{Ameliyathane İç Kullanıcı Yaşlarına Göre Veriler}

Ameliyathane personeline uygulanan ve SPSS programı ile değerlendirme yapılan çalışmada; bir diğer önemli kriter olarak ameliyathane personelinin yaşları ele alınmıştır. Mekân iç kullanıcılarının yaşlarına bağlı olarak çalıştıkları mekân algılamada da farklılıklar olacağı düşünülmüştür. Buna göre beşli likert ölçeği kullanılmış, yaş aralıkları hemşire ve teknisyenlerin işe başlama yaşından akademik personelin son çalışma sınır yaşına kadar eşit aralıklar ile ayrılmış ve sonuçlar personelin yaşları bağlamında değerlendirilmiştir. Ameliyathane iç kullanıcısı ile yapılan çalışmada mekân algısında yaşın önemli olduğu düşünülerek çalışan yaşlarının estetik, güvenlik, işlev gibi başlıklarda etkileri ele alınmıştır. Çalışmada iç kullanıcı olan ameliyathane çalışanlarının yaşları konusunda anlamlı fark bulunmuştur $(p=0,002)$. Çalışmaya katılanlar içerisinde doktorların \%47,3'ü 20-30 yaş, \%25,5'i 31-40 yaş, \%9,1'i 41-50 yaş, \%16,4'ü 51-60 yaş, \%1,8'i 61-70 yaş aralığındadır. Akademik personel arasındaki piramidal örgütlenmenin yaş aralığına da yansıdığı görülmektedir. Çalışmaya katılan yardımcı personelin \%23,5'i 20-30, \%55,9'u 31-40, \%20,6'sı41-50 yaş aralıklarında oldukları görülmektedir. 50 yaş üstü yardımcı personel bulunmamaktadır. Bu durumun ameliyathane çalışma şartlarının zorluğundan kaynaklandığı düşünülmektedir. Mekân algısında 20-30 yaş doktorların ve 31-40 yaş yardımcı personelin, bu aralıklarda yoğunlaşmasından dolayı, etkinliği söz konusudur. Çalışmaya katılanların bulundukları mekânı kullanım süreleri mekânı tanımakta önemlidir. bunun için ameliyathanede çalışma süreleri belirlenmeye çalışıımıştır. Yaş gruplarına göre ameliyathanede personelin çalışma sürelerinde anlamlı fark bulunmuştur $(p=0.000) .20-30$ yaş arası personelin \%39,3'ü 0-1 yıl ve \%42,9'u 1-3 yıl aralığında ameliyathane kullanımını gerçekleştirdiklerini belirtmişlerdir. 31-40 yaş aralığı kullanıcıların ise \%35,7'si 6-10 yıldır aynı ameliyathanede çalışırken, 41-50 yaş arası kullanıcıların \%40,0'ı 10-20 yıl ve yine \%40,0'ı 20 ve üzeri yıldır aynı ameliyathanede çalışmaktadırlar. Çalışma yılları mekânı değerlendirmede yeterli bir süre olarak görülmektedir. Ameliyathanede çalışanların görevli oldukları birimler belirlenmiştir. Ameliyathanede çalışılan bölümde yaşın anlamlı bir fark yaratmadığı görümüştür $(p=0.364)$ (tablo 15).

Tablo 15: Çalışılan Ameliyat Bölümü

20-30 yaş $\mathrm{n}(\%)$ 31-40 yaş $\mathrm{n}(\%)$ 41-50 yaş $\mathrm{n}(\%)$ 51-60 yaş $\mathrm{n}(\%)$ Toplam $\mathrm{n}(\%) \quad \mathrm{p}$

\begin{tabular}{|c|c|c|c|c|c|c|}
\hline Anesteziyoloji ve Reanimasyon & $1(\% 3,4)$ & $0(\% 0,0)$ & $1(\% 14,3)$ & $1(\% 14,3)$ & $3(\% 4,5)$ & 0,364 \\
\hline Beyin ve Sinir Cerrahisi & $0(\% 0,0)$ & $1(\% 4,2)$ & $1(\% 14,3)$ & $1(\% 14,3)$ & $3(\% 4,5)$ & \\
\hline Çocuk Cerrahisi & $2(\% 6,9)$ & $3(\% 12,5)$ & $0(\% 0,0)$ & $0(\% 0,0)$ & $5(\% 7,5)$ & \\
\hline Genel Cerrahi & $2(\% 6,9)$ & $3(\% 12,5)$ & $1(\% 14,3)$ & $0(\% 0,0)$ & $6(\% 9,0)$ & \\
\hline Kadın Hastalıkları ve Doğum & $4(\% 13,8)$ & $3(\% 12,5)$ & $0(\% 0,0)$ & $0(\% 0,0)$ & $7(\% 10,4)$ & \\
\hline Kulak-Burun-Boğaz Hastalıkları & $4(\% 13,8)$ & $7(\% 29,2)$ & $1(\% 14,3)$ & $3(\% 42,9)$ & $15(\% 22,4)$ & \\
\hline Ortopedi ve Travmatoloji & $9(\% 31,0)$ & $5(\% 20,8)$ & $1(\% 14,3)$ & $1(\% 14,3)$ & $16(\% 23,9)$ & \\
\hline Üroloji & $2(\% 6,9)$ & $1(\% 4,2)$ & $1(\% 14,3)$ & $1(\% 14,3)$ & $5(\% 7,5)$ & \\
\hline Göz Hastalıkları & $0(\% 0,0)$ & $0(\% 0,0)$ & $1(\% 14,3)$ & $0(\% 0,0)$ & $1(\% 1,5)$ & \\
\hline Kalp Damar Cerrahisi & $2(\% 6,9)$ & $0(\% 0,0)$ & $0(\% 0,0)$ & $0(\% 0,0)$ & $2(\% 3,0)$ & \\
\hline Plastik Cerrahi & $3(\% 10,3)$ & $1(\% 4,2)$ & $0(\% 0,0)$ & $0(\% 0,0)$ & $4(\% 6,0)$ & \\
\hline Toplam & $29(\% 43,3)$ & $24(\% 35,8)$ & $7(\% 10,4)$ & $7(\% 10,4)$ & $89(\% 100)$ & \\
\hline
\end{tabular}
$\mathrm{p} \leq 0.05$ anlamlı kabul edilmiştir.

Anketi yanıtlayan doktorların yaş aralıklarında anlamlı fark bulunmuştur ( $p=0,000)$. Araştırma görevlilerinin 20-30 yaş ve 31-40 yaş arasında yoğunlukta ve profesörlerin 51-60 yaş aralığında oldukları görüşmüştür. Yardımcı personelin yaş aralıklarında ise anlamlı fark bulunmamaktadır $(p=0,123)$. Yardımcı personel son yaş sınırı 50 olarak tespit edilmiştir. İç kullanıcıların, ameliyathane cerrahi odalarının kullanıma uygun boyutlarda olma durumuna verdikleri cevaplarda yaş grupları arasında anlamlı fark yoktur ( $p=0.239$ ) (tablo 16 ). 20-30 yaşlar \%41,2 (iyi \%32,4, çok iyi \%8,8), 31-40 yaşlar $\% 42,5$ (iyi $\% 36,4$, çok iyi $\% 6,1$ ), $41-50$ yaşlar $\% 50,0$ (iyi $\% 41,7$, çok iyi $\% 8,3$ ) ve $51-60$ yaşlar \%66,7 (iyi \%55,6, çok iyi \%11,1) yüzdelerle odaların kullanıma uygun boyutlandırıldığını belirtmişlerdir. 20-30 yaş \%40,2 (kötü \%17,6, çok kötü \%8,8), 31-40 
yaş \%51,6 (kötü \%33,3, çok kötü \%6,1), 41-50 yaş \%50,0 (kötü \%33,3, çok kötü \%8,3), 51-60 yaş \%22,2 (kötü \%33,3) oranlarında ameliyathane oda boyutlarını olumsuz belirtmişlerdir (tablo 16). Genelde yaş grupları boyutlar konusunda olumsuz görüştedirler.Ameliyathane odalarının mahremiyet koruma düzeyi değerlendirmesinde yaş durumu, anlamlı fark yaratmamaktadır $(p=0,818)$ (tablo 16). 20-30 yaş \%32,4 (iyi $\% 26,5$, çok iyi $\% 5,9$ ), 31-40 yaş $\% 24,3$ (iyi \%18,2, çok iyi $\% 6,1$ ), $41-50$ yaş $\% 16,7$ (iyi $\% 16,7$ ), 51-60 yaş \%55,6 (iyi \%55,6) olarak ameliyathanenin mahremiyet tasarımını olumlu görmektedir. 20-30 yaş $\% 40,2$ (kötü $\% 23,5$, çok kötü $\% 14,7$ ), 31-40 yaş $\% 51,6$ (kötü \%36,4, çok kötü \%15,2), 41-50 yaş \%50,0 (kötü \%33,3, çok kötü \%16,7), 51-60 yaş \%22,2 (kötü \%11,1, çok kötü \%11,1) oranlarında mahremiyet tasarımının uygun olmadığını söylemektedir. Genel olarak konu hakkında olumsuz görüşler mevcuttur (tablo 19). Ameliyathane odalarının mahremiyetinin işitsel ve görsel açıdan sağlama durumunda yaş grupları arasında anlamlı fark bulunmamıştır ( $p=0,853)$ (tablo 16). 2030 yaş \%26,5 (iyi \%20,6, çok iyi \%5,9), 31-40 yaş \%24,2 (iyi \%21,2, çok iyi \%3,0), 41 50 yaş $\% 16,7$ (iyi $\% 16,7$ ), $51-60$ yaş $\% 33,3$ (iyi $\% 33,3$ ) olarak ameliyathanenin mahremiyet tasarımını olumlu görmektedir. 20-30 yaş \%58,8 (kötü \%41,2, çok kötü $\% 17,6$ ), 31-40 yaş $\% 51,5$ (kötü \%39,4, çok kötü \%12,1), 41-50 yaş \%50,0 (kötü \%41,7, çok kötü \%8,3), 51-60 yaş \%33,3 (kötü \%11,1, çok kötü \%22,2) oranlarında görsel ve işitsel mahremiyet tasarımının uygun olmadığını belirtmiştir. Genel olarak konu hakkında olumsuz görüşler ağırlıklıdır (tablo 19). Ameliyathane odalarının içinde bulunan eşyalar ile ele alındığında alanın yeterliliği sorgulanmıştır. Eşyalar için yeterliliği sağlama durumunda yaş grupları arasında anlamlı fark bulunmamıştır $(p=0,310)$ (tablo 19). 20-30 yaş $\% 44,2$ (iyi \%32,4, çok iyi \%11,8), 31-40 yaş \%33,4 (iyi $\% 27,3$, çok iyi $\% 6,1$ ), 41-50 yaş $\% 41,6$ (iyi \%33,3, çok iyi \%8,3), 51-60 yaş \%44,4 (iyi $\% 44,4)$ olarak ameliyat masası vd eşyalar için yeterli alan olduğunu belirtmişlerdir. 2030 yaş \%32,3 (kötü \%23,5, çok kötü \%8,8), 31-40 yaş \%42,5 (kötü \%27,3, çok kötü \%15,2), 41-50 yaş \%23,1 (kötü \%23,1), 51-60 yaş \%44,4 (kötü \%33,3, çok kötü \%11,1) oranları olarak odaların masa ve diğer eşyalar için yetersiz olduğunu söylemişlerdir. Olumlu ve olumsuz görüşler, yaş değişkeninden bağımsız, birbirine eşittir (tablo 16). Ameliyathane odalarının içerisinde bulunması gereken teçhizat ile rahat hareket etme durumu sorgulandığında; yaş grupları arasında anlamlı fark bulunmamıştır $(p=0,372)$ (tablo 19). 20-30 yaş \%47,1 (iyi \%32,4, çok iyi \%14,7), 31-40 yaş \%27,3 (iyi \%18,2, çok iyi \%9,1), 41-50 yaş \%50,0 (iyi \%41,7, çok iyi \%8,3), 51-60 yaş \%44,4 (iyi \%44,4) olarak ameliyathane teçhizatı ile oda içinde rahat hareket etmeyi olumlu nitelendirmiştir. 20-30 yaş \%32,3 (kötü \%14,7, çok kötü \%17,6), 31-40 yaş \%45,5 (kötü $\% 36,4$, çok kötü \%9,1), 41-50 yaş \%41,7 (kötü \%41,7), 51-60 yaş \%44,4 (kötü \%44,4,) oranlarında olumsuz görüş bildirmişlerdir. Olumlu ve olumsuz görüşler, yaş değişkeninden bağımsız, birbirine eşittir (tablo 19). Yine burada da bir önceki tablo verileri gibi olumlu ve olumsuz görüşler birbirine yaklaşık değerdedir. Ameliyathanede kullanılan malzemelerin uygunluğu konusunda; yaş grupları arasında anlamlı fark bulunmamıştır ( $p=0,443$ ) (tablo 16 ). $20-30$ yaş $\% 44,1$ (iyi $\% 35,3$, çok iyi $\% 8,8$ ), 31-40 yaş $\% 54,6$ (iyi $\% 45,5$, çok iyi $\% 9,1$ ), 41-50 yaş $\% 75,0$ (iyi $\% 75,0$ ), 51-60 yaş $\% 55,6$ (iyi $\% 55,6$ ) oranlarında malzemelerin kullanıma uygunluğunu olumlu nitelendirmiştir. 20-30 yaş \%32,3 (kötü \%5,9), 31-40 yaş \%45,5 (kötü \%15,2, çok kötü \%3,0), 41-50 yaş $\% 41,7$ (kötü \%16,7), gibi düşük oranlarda olumsuz görüş bildirmişlerdir (tablo 16). Ameliyathanede kullanılan malzemeler mekân işlevine çoğunlukla uygun bulunmaktadır. Cerrahi odalara girilmeden önce bulunması gereken yıkama/fırçalama sterilizasyon alanlarının kullanıma uygun tasarlanmasında; yaş grupları arasında anlamlı fark bulunmuştur ( $p=0,031$ ) (tablo 16). 20-30 yaş \%38,2 (iyi $\% 23,5$, çok iyi $\% 14,7$ ), 31-40 yaş $\% 42,4$ (iyi \%42,4), 41-50 yaş $\% 50,0$ (iyi \%33,3), 51-60 yaş \%44,4 (iyi \%44,4) olarak ameliyathane teçhizatı ile oda içinde rahat hareket etmeyi olumlu nitelendirmiştir. 20-30 yaş \%17,6 (kötü \%8,8, çok kötü \%8,8), 31-40 yaş \%27,3 (kötü $\% 18,2$, çok kötü \%9,1), 41-50 yaş \%58,3 (kötü \%58,3), 51-60 yaş \%33,3 (kötü \%22,2, 
çok kötü \%11,1) oranlarında olumsuz görüş bildirmişlerdir. Burada 20-30 yaş grubunda yıkama/fırçalama alanlarının uygunluğu konusunda \%44,1 gibi yüksek oranla karasız oldukları görülmektedir (tablo 16). Bu grupta bulunan çalışanlar yeni işe başlayan yardımcı personel ve asistan düzeyindeki doktorlardır. Dolayısı ile alanın uygunluğunu zamanla kullanarak deneyimlemeleri gerekeceğinden böyle bir sonuç ortaya çıktığı düşünülmektedir. Çalışanların yaşının ilerlemesi ile daha net bir kullanıma yönelik fikirlerinin oluştuğu gözlemlenmiştir. Üst yaş grubu olumlu yaklaşırken alt yaş grubu kararsız görülmüştür. Ameliyathane odasının herkes tarafından kolay kullanımının düşünülmüş olması konusunda; yaş grupları arasında anlamlı fark bulunmamıştır $(p=0,756)$ (tablo 16). 20-30 yaş $\% 38,2$ (iyi $\% 29,4$, çok iyi $\% 8,8$ ), 31-40 yaş $\% 21,2$ (iyi $\% 18,2$, çok iyi $\% 3,0$ ), 41-50 yaş $\% 41,6$ (iyi \%33,3, çok iyi $\% 8,3$ ), $51-60$ yaş $\% 33,3$ (iyi $\% 22,2$, çok iyi \%11,1) oranlarında olumlu görüş bildirmişlerdir. 20-30 yaş \%32,3 (kötü $\% 23,5, \% 2,9$ ), 31-40 yaş \%45,5 (kötü \%24,2, çok kötü \%6,1), 51-60 yaş \%11,1 (kötü $\% 11,1$ ) oranlarda olumsuz görüş bildirmişlerdir (tablo 16). Burada en dikkat çeken konu ise; $20-30$ yaş $(35,3), 31-40$ yaş $(\% 48,5)$ ve $51-60$ yaş $(\% 55,6)$ aralıklarında karasızların oranının yüksek olmasıdır. Burada başka bir ameliyathane ortamında çalışılmadığı için kıyaslama yapılamamasına bağlı olarak karasız kalındığı düşünülmektedir. Ameliyathanenin hasta ya da çalışan engelli kişilere yönelik tasarlanması konusunda; yaş grupları arasında anlamlı fark bulunmamıştır $(p=0,366)$ (tablo 16). 20-30 yaş \%17,7 (iyi \%11,8, çok iyi \%5,9), 31-40 yaş \%21,2 (iyi \%21,2), 4150 yaş \%33,3 (iyi \%33,3), 51-60 yaş \%22,2 (iyi \%11,1, çok iyi \%11,1) oranlarında olumlu görmüşlerdir. 20-30 yaş \%55,9 (kötü \%26,5, çok kötü \%29,4), 31-40 yaş \%51,5 (kötü \%24,2, çok kötü \%27,3), 51-60 yaş \%33,3 (kötü \%11,1, çok kötü \%22,2) oranlarda olumsuz görüş bildirmişlerdir (tablo 16).

Tablo 16: Ameliyathane odaları kullanıma uygun boyutlandırılması

\begin{tabular}{l|ccccccc} 
& $20-30$ yaş $\mathrm{n}(\%)$ & $31-40$ yaş $\mathrm{n}(\%)$ & $41-50$ yaş $\mathrm{n}(\%)$ & $51-60 y a s ̧ \mathrm{n}(\%)$ & $61-70$ yaş $\mathrm{n}(\%)$ & Toplam $\mathrm{n}(\%)$ & $\mathrm{p}$ \\
\hline Çok kötü & $3(\% 8,8)$ & $2(\% 6,1)$ & $1(\% 8,3)$ & $0(\% 0,0)$ & $0(\% 0,0)$ & $\mathbf{6}(\% 6,7)$ & $\mathbf{0 , 2 3 9}$ \\
Kötü & $6(\% 17,6)$ & $11(\% 33,3)$ & $4(\% 33,3)$ & $3(\% 33,3)$ & $0(\% 0,0)$ & $\mathbf{2 4}(\% 27,0)$ \\
Kararsız & $11(\% 32,4)$ & $6(\% 18,2)$ & $1(\% 8,3)$ & $0(\% 0,0)$ & $0(\% 0,0)$ & $\mathbf{1 8}(\% 20,2)$ \\
lyi & $11(\% 32,4)$ & $12(\% 36,4)$ & $5(\% 41,7)$ & $5(\% 55,6)$ & $0(\% 0,0)$ & $\mathbf{3 3}(\% 37,1)$ \\
Çok iyi & $3(\% 8,8)$ & $2(\% 6,1)$ & $1(\% 8,3)$ & $1(\% 11,1)$ & $1(\% 100)$ & $\mathbf{8 ( \% 9 , 0 )}$ \\
\hline TOPLAM & $\mathbf{3 4}(\% 38,2)$ & $\mathbf{3 3 ( \% 3 7 , 1 )}$ & $\mathbf{1 2 ( \% 1 3 , 5 )}$ & $\mathbf{9 ( \% 1 0 , 1 )}$ & $\mathbf{1 ( \% 1 , 1 )}$ & $\mathbf{8 9 ( \% 1 0 0 )}$ \\
\hline
\end{tabular}

Ameliyathane odaları mahremiyeti koruyacak şekilde tasarlanması

\begin{tabular}{|c|c|c|c|c|c|c|c|}
\hline Çok kötü & $5(\% 14,7)$ & $5(\% 15,2)$ & $2(\% 16,7)$ & $1(\% 11,1)$ & $0(\% 0,0)$ & $13(\% 14,6)$ & 0,818 \\
\hline Kötü & $8(\% 23,5)$ & $12(\% 36,4)$ & $4(\% 33,3)$ & $1(\% 11,1)$ & $0(\% 0,0)$ & $25(\% 28,1)$ & \\
\hline Kararsız & $10(\% 29,4)$ & $8(\% 24,2)$ & $4(\% 33,3)$ & $2(\% 22,2)$ & 1 (\%100) & $\% 28,1)$ & \\
\hline & $9(\% 26,5)$ & $6(\% 18,2)$ & $2(\% 16,7)$ & $5(\% 55,6)$ & $0(\% 0,0)$ & $22(\% 24,7)$ & \\
\hline Çok iyi & $2(\% 5,9)$ & $2(\% 6,1)$ & $0(\% 0,0)$ & $0(\% 0,0)$ & $0(\% 0,0)$ & $4(\% 4,5)$ & \\
\hline TOPLAM & $34(38,2)$ & $33(\% 37,1)$ & $12(\% 13,5)$ & $9(\% 10,1)$ & $1(\% 1,1)$ & $89(\% 100)$ & \\
\hline \multicolumn{8}{|c|}{ Mahremiyet hem görsel hem işitsel açıdan sağlanması } \\
\hline ok kötü & $6(\% 17,6)$ & $4(\% 12,1)$ & $1(\% 8,3)$ & $2(\% 22,2)$ & $0(\% 0,0)$ & $13(\% 14,6)$ & 0,853 \\
\hline Kötü & $14(\% 41,2)$ & $13(\% 39,4)$ & $5(\% 41,7)$ & $1(\% 11,1)$ & $0(\% 0,0)$ & $33(\% 37,1)$ & \\
\hline Kararsız & $5(\% 14,7)$ & $8(\% 24,2)$ & $4(\% 33,3)$ & $3(\% 33,3)$ & $0(\% 0,0)$ & $21(\% 23,6)$ & \\
\hline İyi & $7(\% 20,6)$ & $7(\% 21,2)$ & $2(\% 16,7)$ & $3(\% 33,3)$ & $0(\% 0,0)$ & $19(\% 21,3)$ & \\
\hline Çok iyi & $2(\% 5,9)$ & $1(\% 3,0)$ & $0(\% 0,0)$ & $0(\% 0,0)$ & 1 (\%100) & $3(\% 3,4)$ & \\
\hline TOPLAM & $34(\% 38,2)$ & $33(\% 37,1)$ & $12(\% 13,5)$ & $9(\% 10,1)$ & $1(\% 1,1)$ & 89 (\%100) & \\
\hline \multicolumn{8}{|c|}{ Ameliyat masası ve diğer eşyalar için yeterli alan olması } \\
\hline & & $5(\% 15,2)$ & & $1(\% 11,1)$ & & $9(\% 10,1)$ & 0,310 \\
\hline $\mathrm{K}$ & $8(\% 23,5)$ & $9(\% 27,3)$ & $6(\% 23,1)$ & $3(\% 33,3)$ & $0(\% 0,0)$ & $26(\% 29,2)$ & \\
\hline Karar & $8(\% 23,5)$ & $8(\% 24,2)$ & $1(\% 8,3)$ & $1(\% 11,1)$ & $0(\% 0,0)$ & $18(\% 20,2)$ & \\
\hline İyi & $11(\% 32,4)$ & $9(\% 27,3)$ & $4(\% 33,3)$ & $4(\% 44,4)$ & $0(\% 0,0)$ & $\% 31,5)$ & \\
\hline Çok iyi & $4(\% 11,8)$ & $2(\% 6,1)$ & $1(\% 8,3)$ & $0(\% 0,0)$ & $1(\% 100)$ & $8(\% 9,0)$ & \\
\hline TOPLAM & $34(\% 38,2)$ & $33(\% 37,1)$ & $12(\% 13,5)$ & $9(\% 10,1)$ & $1(\% 1,1)$ & 89 (\%100) & \\
\hline \multicolumn{8}{|c|}{ Ameliyathane teçhizatı ile oda içinde rahatça hareket etme durumu } \\
\hline Çok kötü & $6(\% 17,6)$ & $3(\% 9,1)$ & $0(\% 0,0)$ & $0(\% 0,0)$ & $0(\% 0,0)$ & $9(\% 10,1)$ & 0,372 \\
\hline Kötü & $5(\% 14,7)$ & $12(\% 36,4)$ & $5(\% 41,7)$ & $4(\% 44,4)$ & $0(\% 0,0)$ & $26(\% 29,2)$ & \\
\hline Kararsız & $7(\% 20,6)$ & $9(\% 27,3)$ & $1(\% 8,3)$ & $1(\% 11,1)$ & $0(\% 0,0)$ & $18(\% 20,2)$ & \\
\hline & $11(\% 32,4)$ & $6(\% 18,2)$ & $5(\% 41,7)$ & $4(\% 44,4)$ & 1 (\%100) & $\% 30,3)$ & \\
\hline Çok iyi & $5(\% 14,7)$ & $3(\% 9,1)$ & $1(\% 8,3)$ & $0(\% 0,0)$ & $0(\% 0,0)$ & $9(\% 10,1)$ & \\
\hline TOPLAM & $34(\% 38,2)$ & $33(\% 37,1)$ & $12(\% 13,5)$ & $9(\% 10,1)$ & $1(\% 1,1)$ & $89(\% 100)$ & \\
\hline
\end{tabular}


Ameliyathanede kullanılan malzemeler kullanıma uygunluğu

\begin{tabular}{l|ccccccc}
\hline Çok kötü & $0(\% 0,0)$ & $1(\% 3,0)$ & $0(\% 0,0)$ & $0(\% 0,0)$ & $0(\% 0,0)$ & $\mathbf{1}(\% 1, \mathbf{1})$ & $\mathbf{0 , 4 4 3}$ \\
Kötü & $2(\% 5,9)$ & $5(\% 15,2)$ & $2(\% 16,7)$ & $0(\% 0,0)$ & $0(\% 0,0)$ & $\mathbf{9 ( \% 1 0 , 1 )}$ & \\
Kararsız & $17(\% 50,0)$ & $9(\% 27,3)$ & $1(\% 8,3)$ & $4(\% 44,4)$ & $0(\% 0,0)$ & $\mathbf{3 1}(\% 34,8)$ \\
İyi & $12(\% 35,3)$ & $15(\% 45,5)$ & $9(\% 75,0)$ & $5(\% 55,6)$ & $1(\% 100)$ & $\mathbf{4 2}(\% 47,2)$ \\
Çok iyi & $3(\% 8,8)$ & $3(\% 9,1)$ & $0(\% 0,0)$ & $0(\% 0,0)$ & $0(\% 0,0)$ & $\mathbf{6}(\% 6,7)$ & \\
\hline TOPLAM & $\mathbf{3 4}(\% 38,2)$ & $\mathbf{3 3 ( \% 3 7 , 1 )}$ & $\mathbf{1 2}(\% 13,5)$ & $\mathbf{9 ( \% 1 0 , 1 )}$ & $\mathbf{1 ( \% 1 , 1 )}$ & $\mathbf{8 9 ( \% 1 0 0 )}$
\end{tabular}

Ameliyathane odalarına giriş ünitesi (sterilizasyon gibi) kullanıma uygun tasarlanması

\begin{tabular}{|c|c|c|c|c|c|c|c|}
\hline Çok kötü & $3(\% 8,8)$ & $3(\% 9,1)$ & $0(\% 0,0)$ & $1(\% 11,1)$ & $0(\% 0,0)$ & $7(\% 7,9)$ & 0,031 \\
\hline Kötü & $3(\% 8,8)$ & $6(\% 18,2)$ & $7(\% 58,3)$ & $2(\% 22,2)$ & $0(\% 0,0)$ & $18(\% 20,2)$ & \\
\hline Kararsız & $15(\% 44,1)$ & $10(\% 30,3)$ & $1(\% 8,3)$ & $2(\% 22,2)$ & $0(\% 0,0)$ & $28(\% 31,5)$ & \\
\hline İyi & $8(\% 23,5)$ & $14(\% 42,4)$ & $4(\% 33,3)$ & $4(\% 44,4)$ & 1 (\%100) & $31(\% 34,8)$ & \\
\hline Çok iyi & $5(\% 14,7)$ & $0(\% 0,0)$ & $0(\% 0,0)$ & $0(\% 0,0)$ & $0(\% 0,0)$ & $5(\% 5,6)$ & \\
\hline TOPLAM & $33(\% 38,2)$ & $33(\% 37,1)$ & 12(\%13,5) & $9(\% 10,1)$ & $1(\% 1,1)$ & 89 (\%100) & \\
\hline
\end{tabular}

Ameliyathane odasının herkes tarafından kolay kullanımı düşünülmesi

\begin{tabular}{|c|c|c|c|c|c|c|c|}
\hline Çok kötü & $1(\% 2,9)$ & $2(\% 6,1)$ & $0(\% 0,0)$ & $0(\% 0,0)$ & $0(\% 0,0)$ & $3(\% 3,4)$ & 0,756 \\
\hline Kötü & $8(\% 23,5)$ & $8(\% 24,2)$ & $5(\% 0,0)$ & $1(\% 11,1)$ & $0(\% 0,0)$ & $22(\% 24,7)$ & \\
\hline Kararsız & $12(\% 35,3)$ & $16(\% 48,5)$ & $2(\% 16,7)$ & $5(\% 55,6)$ & $0(\% 0,0)$ & $35(\% 39,3)$ & \\
\hline İyi & $10(\% 29,4)$ & $6(\% 18,2)$ & $4(\% 33,3)$ & $2(\% 22,2)$ & $1(\% 100)$ & $23(\% 25,8)$ & \\
\hline Çok iyi & $3(\% 8,8)$ & $1(\% 3,0)$ & $1(\% 8,3)$ & $1(\% 11,1)$ & $0(\% 0,0)$ & $6(\% 6,7)$ & \\
\hline TOPLAM & $34(\% 38,2)$ & $33(\% 37,1)$ & $12(\% 13,5)$ & $9(\% 10,1)$ & $1(\% 1,1)$ & 89 (\%100) & \\
\hline \multicolumn{8}{|c|}{ Ameliyathane odaları engelliler için uygun tasarlanması } \\
\hline Çok kötü & $10(\% 29,4)$ & $9(\% 27,3)$ & $0(\% 0,0)$ & $2(\% 22,2)$ & $0(\% 0,0)$ & $21(\% 23,6)$ & 0,366 \\
\hline Kötü & $9(\% 26,5)$ & $8(\% 24,2)$ & $6(\% 50,0)$ & $1(\% 11,1)$ & $0(\% 0,0)$ & $24(\% 27,0)$ & \\
\hline Kararsız & $9(\% 26,5)$ & $9(\% 27,3)$ & $2(\% 16,7)$ & $4(\% 44,4)$ & $1(\% 100)$ & $25(\% 28,1)$ & \\
\hline & $4(\% 11,8)$ & $7(\% 21,2)$ & $4(\% 33,3)$ & $1(\% 11,1)$ & $0(\% 0,0)$ & $16(\% 18,0)$ & \\
\hline Çok iyi & $2(\% 5,9)$ & $0(\% 0,0)$ & $0(\% 0,0)$ & $1(\% 11,1)$ & $0(\% 0,0)$ & $3(\% 3,4)$ & \\
\hline TOPLAM & $34(\% 38,2)$ & $33(\% 37,1)$ & $12(\% 13,5)$ & $9(\% 10,1)$ & $1(\% 1,1)$ & 89 (\%100) & \\
\hline
\end{tabular}

$\mathrm{p} \leq 0.05$ anlamlı kabul edilmiştir.

Ameliyathanede genel tüm odaların gün ışığı alma durumuna verilen yanıtlarda yaş grupları arasında anlamlı fark bulunmuştur $(p=0,000)$ (tablo 17). Olumlu görüş bildirenlerin oranı toplamda çok düşük oranda kalmıştır. 20-30 yaş \%93,8 (kötü \%9,4, çok kötü \%84,4), 31-40 yaş \%94,0 (kötü \%18,2, çok kötü \%75,8), $41-50$ yaş \%83,3 (kötü \%50,0, çok kötü \%33,3), 51-60 yaş \%66,7 (kötü \%11,1, çok kötü \%55,6) oranlarda olumsuz görüş bildirmişlerdir (tablo 20). Yaş grupları arasındaki farkın \%6,3 oran ile çok iyi görüş bildiren 20-30 yaş grubu oluşturmaktadır. Bu yaş grubundaki asistanların ve yeni çalışmaya başlayan yardımcı personelin mekan algılarında deneyimsizlik olduğu düşünülmektedir. Bu kadar yüksek oranla belirtilen ortam için mutlaka iç ortam ölçümlerinin yapılması gereklidir. Ameliyathanede genel tüm odaların manzara görme-dış ortam ile ilişkili olma durumuna verilen yanıtlarda yaş grupları arasında anlamlı fark bulunmuştur $(p=0,001)$ (tablo 17). Olumlu görüş bildirenlerin oranı bu istatistiksel bulgularda da toplamda çok düşük oranda kalmıştır. 20-30 yaş \%93,8 (kötü \%12,5, çok kötü \%81,3), 31-40 yaş \%93,9 (kötü \%12,1, çok kötü \%81,8), 41-50 yaş \%91,7 (kötü \%50,0, çok kötü \%41,7), 51-60 yaş \%88,9 (kötü \%22,2, çok kötü $\% 66,7$ ) oranlarda olumsuz görüş bildirmişlerdir (tablo 20). Bu verilerde yaş grupları arasındaki farkı ise yine \%6,3 oran ile çok iyi görüş bildiren 20-30 yaş grubu oluşturmaktadır. Yukarıdaki yorumlarla paralel olarak 20-30 yaş grubundaki personelin mekân algılarında deneyimsizlik olduğu düşünülmektedir. Ameliyathane iç mekân tasarımının çalışanlar üzerindeki etkisinde yaş grupları arasında anlamlı fark bulunmamıştır ( $\mathrm{p}=0,057$ ) (tablo 20). 20-30 yaş \%12,2 (iyi \%6,1, çok iyi \%6,1), 31-40 yaş \%12,2 (iyi \%12,1), 41-50 yaş \%8,3 (iyi \%8,3), 51-60 yaş \%44,4 (iyi \%44,4) oranlarında olumlu görmüşlerdir. 20-30 yaş \%51,5 (kötü \%30,3, çok kötü \%21,2), 31-40 yaş \%66,7 (kötü \%30,3, çok kötü \%36,4), 51-60 yaş \%44,4 (kötü \%33,3, çok kötü $\% 11,1$ ) oranlarda olumsuz görüş bildirmişlerdir (tablo 17). Yaş gruplarına göre de iç mekân tasarımlarının çalışanlar açısından olumsuz bulunması, kesinlikle konu üzerinde eğilmesi gerektiğinin göstergesidir. Ameliyathanede sıcak (kırmızı, turuncu, sarı), soğuk (mavi, yeşil), nötr (beyaz ve tonları) olarak belirlenen renklerin durumuna verilen yanıtlarda yaş grupları arasında anlamlı fark bulunmamaktadır $(p=0,876)$ (tablo 17). Ameliyathane renklerini $20-30$ yaş $\% 12,5,31-40$ yaş $\% 15,6$ düşük oranlarda sıcak 
renkler olduğunu görmüşlerdir. Ameliyathane renklerini; 20-30 yaş \%46,9, 31-40 yaş $\% 37,5,41-50$ yaş $\% 45,5,51-60$ yaş $\% 42,9$ oranlarında soğuk renkler olduğu görüşüne sahipken; $20-30$ yaş $\% 3,1,41-50$ yaş $\% 54,5,51-60$ yaş $\% 57,1$ oranlarında nötr renkler görüş bildirmişlerdir (tablo 17). Ameliyathanede kullanılan malzemelerin (mobilya yatak vb. cerrahi için gerekli donanım) yüzey kaplamalarının pürüzsüz, hijyenik, kolay temizlenir ve estetik kaygıları olan malzemelerden olması durumuna verilen yanıtlarda yaş aralıklarıkları arasında anlamlı fark bulunmuştur ( $p=0,004)$ (tablo 17). 20-30 yaş $\% 57,1,31-40$ yaş $\% 62,5,41-50$ yaş $\% 75,0,51-60$ yaş $\% 50$ oranlarında pürzsüz hijyenik olması gerek derken, 20-30 yaş \%39,3, 31-40 yaş \%37,5, 41-50 yaş \%25,0 oranlarında kolay temizlenir olmasının önemli olduğunu belirtmişlerdir (tablo 17). Burada asıl farkı yaratan ise 51-60 yaş grubunun \%50 oranında estetik kaygıları olan kaplama dokularının olması gerektiğini söylemektedirler. Ameliyathane cerrahi odalarda ve diğer odalarda estetik ögelerin yeterli ve doğru kullanımına verilen yanıtlarda yaş grupları arasında anlamlı fark bulunmamaktadır ( $p=0,736)$ (tablo 20). 2030 yaş $\% 11,7$ (iyi $\% 8,8$, çok iyi $\% 2,9$ ), $31-40$ yaş $\% 9,1$ (iyi $\% 9,1$ ), $41-50$ yaş $\% 9,1$ (iyi $\% 9,1$ ), 51-60 yaş $\% 22,2$ (iyi $\% 22,2$ ) oranlarında olumlu görmüşlerdir. 20-30 yaş $\% 52,9$ (kötü \%38,2, çok kötü \%14,7), 31-40 yaş \%60,6 (kötü \%24,2, çok kötü \%36,4), 41-50 yaş \%54,6 (kötü \%45,5, çok kötü \%9,1), 51-60 yaş \%55,5 (kötü \%22,2, çok kötü $\% 33,3$ ) oranlarda olumsuz görüş bildirmişlerdir (tablo 17). Ameliyathanede kullanılan estetik ögelerin doğru ve yeterli kullanım kaygıları düşünülerek seçilmediği işlevsel kaygıların ön planda olduğu açıktır. Ameliyathane genelinde malzeme seçimlerinin estetik olup olmamasına yönelik verilen yanıtlarda yaş gurupları arasında cevapları arasında anlamlı fark bulunmamıştır ( $p=0,245$ ) (Tablo 17). 20-30 yaş \%5,9 (iyi \%5,9), $31-40$ yaş $\% 15,6$ (iyi $\% 15,6$ ), 41-50 yaş $\% 18,2$ (iyi $\% 9,1$, çok iyi $\% 9,1$ ), 51-60 yaş $\% 11,1$ (iyi $\% 11,1$ ) oranlarında olumlu görmüşlerdir. 20-30 yaş $\% 55,9$ (kötü $\% 41,2$, çok kötü \%14,7), 31-40 yaş \%56,3 (kötü \%18,8, çok kötü \%37,5), 41-50 yaş \%63,7 (kötü $\% 45,5$, çok kötü \%18,2), 51-60 yaş \%44,4 (kötü \%22,2, çok kötü \%22,2) oranlarda olumsuz görüş bildirmişlerdir (tablo 17). Ameliyathanede kullanılan malzemelerin estetik düşünülerek seçilmediği işlevsel kaygıların ön planda olduğu görülmektedir.

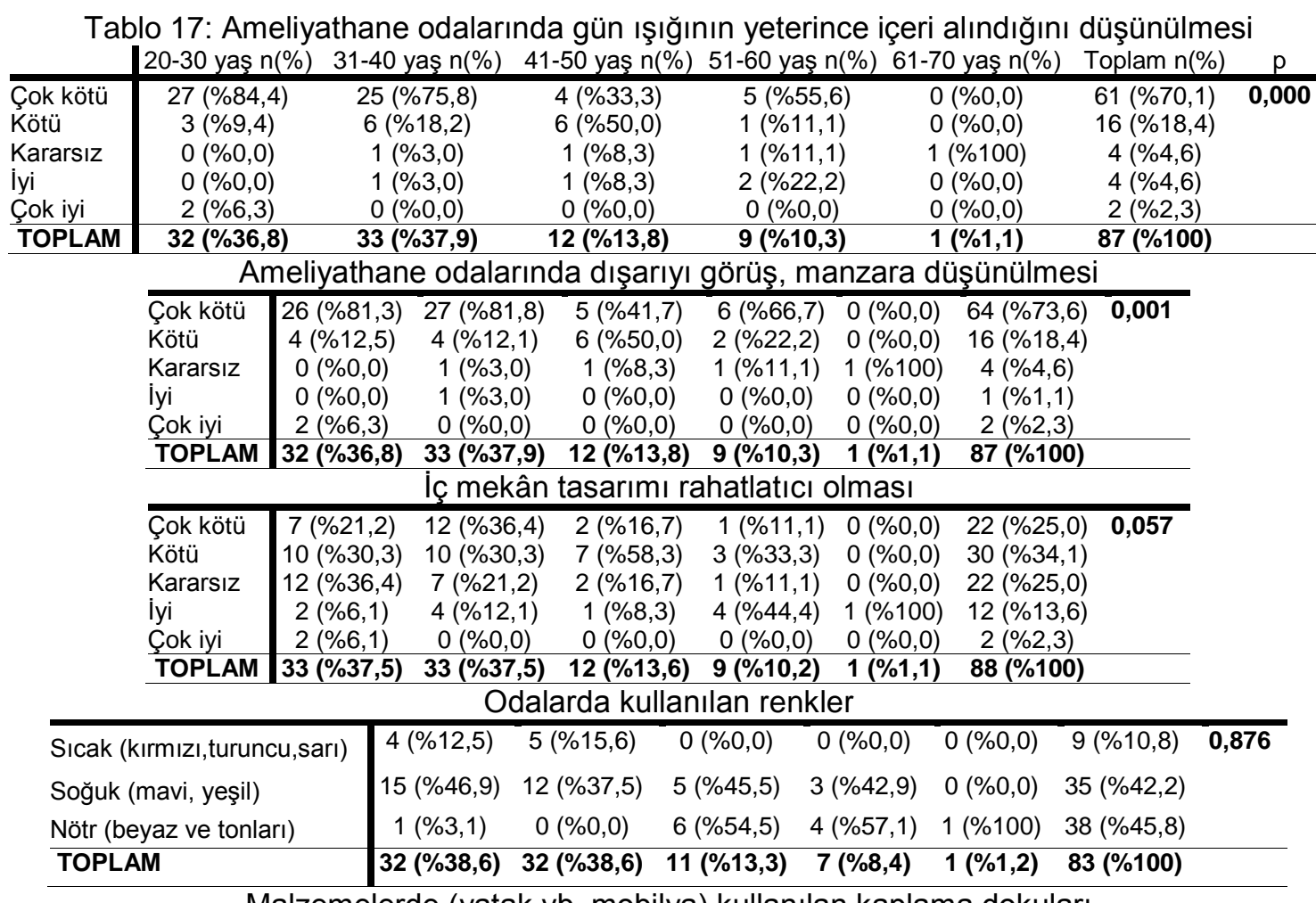

Malzemelerde (yatak vb. mobilya) kullanılan kaplama dokuları 
Ameliyathane Performanslarının İç Kullanıcı Memnuniyeti Açısından İncelenmesi; Erciyes Üniversitesi Gevher Nesibe Hastanesi Örneği Investigation of Operating Room Performances in Terms of Internal User Satisfaction; an Example of a University Hospital

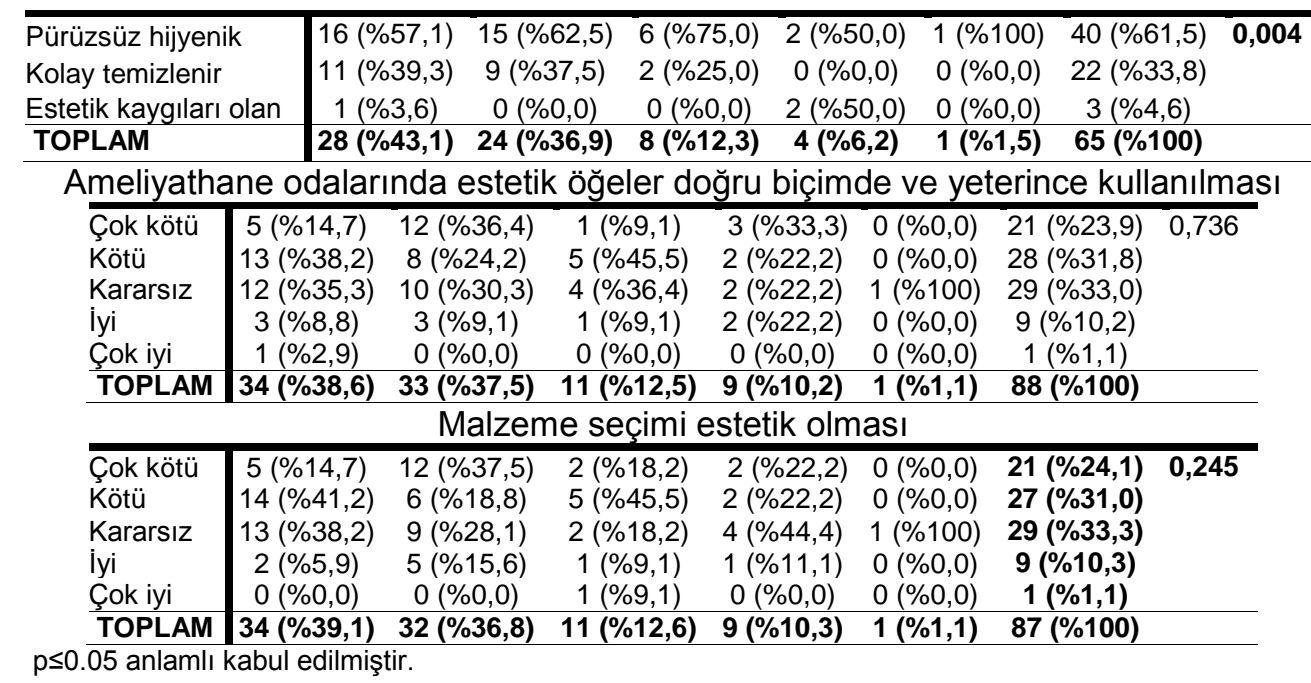

Ameliyathane iç ortam ısısal konforuna verilen cevaplarda yaş grupları cevaplarında anlamlı fark bulunmamıştır ( $p=0,909$ ) (Tablo 21). 20-30 yaş \%44,1 (iyi \%29,4, çok iyi $\% 14,7$ ), 31-40 yaş $\% 42,5$ (iyi $\% 27,3$, çok iyi $\% 15,2$ ), $41-50$ yaş $\% 33,4$ (iyi $\% 16,7$, çok iyi \%16,7), 51-60 yaş \%22,2 (iyi \%22,2) oranlarında olumlu görmüşlerdir. 20-30 yaş $\% 29,4$ (kötü \%20,6, çok kötü \%8,8), 31-40 yaş \%42,4 (kötü \%24,2, çok kötü \%18,2), $41-50$ yaş \%41,7 (kötü \%25,0, çok kötü \%16,7), 51-60 yaş \%33,3 (kötü \%22,2, çok kötü \%11,1) oranlarda olumsuz görüş bildirmişlerdir (tablo 21). İç mekân ısısal konforun sağlanması ve ısısal ölçümlerin yapılması gereklidir. Bunlar yapılırken yaş durumları da gibi kişisel veriler de değerlendirilmelidir. Ameliyathanede rahatsız edici kokulara yönelik önlem alınıp alınmadığı sorularak iç ortam hava kalitesinin irdelendiği soruya verilen cevaplarda yaş grupları arasında anlamlı fark bulunmamıştır $(p=0,125)$ (Tablo 18). 20-30 yaş $\% 44,1$ (iyi $\% 38,2$, çok iyi $\% 5,9$ ), 31-40 yaş $\% 21,2$ (iyi $\% 9,1$, çok iyi \%12,1), 41-50 yaş \%16,7 (iyi \%16,7), 51-60 yaş \%44,4 (iyi \%44,4) oranlarında olumlu görmüşlerdir. 20-30 yaş \%29,4 (kötü \%14,7, çok kötü \%14,7), 31-40 yaş \%51,5 (kötü \%24,2, çok kötü \%27,3), 41-50 yaş \%66,7 (kötü \%25,0, çok kötü \%41,7), 51-60 yaş \%11,1 (kötü \%11,1) oranlarda olumsuz görüş bildirmişlerdir (tablo 18). Toplam yaş gruplarında \%27 oranında karasız kalınmıştır. Tüm yaş grupları için kokulara karşı önlem alınmasında problem olduğu görüşü çoğunluktadır. Çalışma ortamı ölçümlerinin yapılması ve yapılırken kişisel verilerden olan yaşın da göz önüne alınarak yapılması gerekmektedir. Çalışma ortamı konforuna yönelik diğer konu olan ameliyathane aydınlatma, parlama ve göz almaya yönelik tasarımları irdelemede ameliyathanenin yapay aydınlatma durumu belirlenmek istenmiştir. Personel yaş gruplarının konuya yaklaşımında anlamlı fark bulunmamıştır $(p=0,144)$ (Tablo 18$)$. $20-30$ yaş $\% 50$ (iyi $\% 47,1$, çok iyi \%2,9), 31-40 yaş \%33,5 (iyi \%27,3, çok iyi \%6,1), 41-50 yaş \%25 (iyi $\% 16,7$, çok iyi \%8,3), 51-60 yaş \%55,6 (iyi \%55,6) oranlarında olumlu görmüşlerdir. 2030 yaş \%29,4 (kötü \%11,8, çok kötü \%8,8), 31-40 yaş \%51,5 (kötü \%21,2, çok kötü $\% 21,2$ ), 41-50 yaş \%66,7 (kötü \%58,3, çok kötü \%8,3), 51-60 yaş \%11,1 (kötü \%11,1) oranlarda olumsuz görüş bildirmişlerdir (tablo 18). Toplamda yaş gruplarında \%24,7 oranında karasızlar bulunmaktadır. 20-30 yaş ve 51-60 yaş aralığındaki çalışanlar genelde daha iyi görüş bildirirken 41-50 yaş aralığının ise olumsuz görüş bildirmesi ilginçtir. Aydınlatma ölçümleri, mutlaka yaş ele alınarak yapılmalıdır. Ameliyathanede odaların yapay havalandırma durumu sorulmuş ve iç ortam yapay havalandırma durumu incelenmiştir. Verilen cevaplarda yaş grupları arasında anlamlı fark bulunmuştur ( $p=0,027$ ) (Tablo 18). 20-30 yaş $\% 53$ (iyi $\% 32,4$, çok iyi $\% 20,6), 31-40$ yaş $\% 39,4$ (iyi $\% 36,4$, çok iyi \%3,0), 41-50 yaş \%16,7 (iyi \%16,7), 51-60 yaş \%55,5 (iyi $\% 44,4$, çok iyi 11,1 ) oranlarında olumlu düşünmektedirler. 20-30 yaş \%17,6 (kötü $\% 14,7$, çok kötü \%2,9), 31-40 yaş \%39,4 (kötü \%12,1, çok kötü \%27,3), 41-50 yaş 
$\% 66,7$ (kötü \%41,7, çok kötü \%25,0) oranlarda olumsuz düşünmektedirler (tablo 18). $\% 27,0$ oranında ise karasızlık görülmüştür. 51-60 yaş aralığında bulunan çalışanların diğerlerine göre havalandırmayı yüksek oranda olumlu görmeleri buna karşın diğer yaş aralıklarında olan çalışanların olumsuz bulmaları söz konusudur. Konu üzerinde detaylı araştırmaların yapılması önemlidir. Burada yine iç ortam ölçümleri yapılırken yaş veri olarak alınması gerekliliği ortaya çıkmaktadır. Ameliyathanede ses izolasyonunun durumuna verilen cevaplarda personelin yaş durumlarına göre anlamlı fark bulunmamaktadır ( $p=0,762$ ) (Tablo 18 ). 20-30 yaş \%14,7 (iyi \%14,7), 31-40 yaş \%18,2 (iyi \%12,1, çok iyi \%6,1), 51-60 yaş \%11,1 (iyi \%11,1) oranlarında olumlu görüşe sahiptir. 20-30 yaş \%61,7 (kötü \%44,1, çok kötü \%17,6), 31-40 yaş \%57,6 (kötü \%30,3, çok kötü \%27,3), 41-50 yaş \%83,3 (kötü \%58,3, çok kötü \%25,0), 51-60 yaş \%. 66,6 (kötü \%33,3, çok kötü \%33,3) oranlarda olumsuz görüş bildirmişlerdir (tablo 18). Toplamda \%23,6 ise karasızdır. Her yaş gurubunun da çoğunlukla belirttiği durum ses izolasyonunun iyi olmadığı yönündedir.

Tablo 18: Ameliyathane ısısal konfor sağlanması

20-30 yaş $\mathrm{n}(\%) \quad 31-40$ yaş $\mathrm{n}(\%) \quad$ 41-50 yaş $\mathrm{n}(\%) \quad 51-60$ yaş $\mathrm{n}(\%) \quad 61-70$ yaş $\mathrm{n}(\%) \quad$ Toplam $\mathrm{n}(\%) \quad \mathrm{p}$

\begin{tabular}{|c|c|c|c|c|c|c|c|}
\hline Çok kötü & $3(\% 8,8)$ & $6(\% 18,2)$ & $2(\% 16,7)$ & $1(\% 11,1)$ & $0(\% 0,0)$ & $12(\% 13,5)$ & 0,909 \\
\hline Kötü & $7(\% 20,6)$ & $8(\% 24,2)$ & $3(\% 25,0)$ & $2(\% 22,2)$ & $0(\% 0,0)$ & $20(\% 22,5)$ & \\
\hline Kararsız & $9(\% 26,5)$ & $5(\% 15,2)$ & $3(\% 25,0)$ & $4(\% 44,4)$ & 1 (\%100) & $22(\% 24,7)$ & \\
\hline İyi & $10(\% 29,4)$ & $9(\% 27,3)$ & $2(\% 16,7)$ & $2(\% 22,2)$ & $0(\% 0,0)$ & $23(\% 25,8)$ & \\
\hline Çok iyi & $5(\% 14,7)$ & $5(\% 15,2)$ & $2(\% 16,7)$ & $0(\% 0,0)$ & $0(\% 0,0)$ & $12(\% 13,5)$ & \\
\hline TOPLAM & $34(\% 38,2)$ & $33(\% 37,1)$ & $12(\% 13,5)$ & $9(\% 10,1)$ & $1(\% 1,1)$ & $89(\% 100)$ & \\
\hline
\end{tabular}

Ameliyathane odalarında rahatsız edici kokulara (ilaç, tuvalet, yemek vb.) karşı önlem alınması

\begin{tabular}{l|ccccccc}
\hline Çok kötü & $5(\% 14,7)$ & $9(\% 27,3)$ & $5(\% 41,7)$ & $0(\% 0,0)$ & $0(\% 0,0)$ & $\mathbf{1 9}(\% \mathbf{2 1}, \mathbf{3})$ & $\mathbf{0 , 1 2 5}$ \\
Kötü & $5(\% 14,7)$ & $8(\% 24,2)$ & $3(\% 25,0)$ & $1(\% 11,1)$ & $1(\% 100)$ & $\mathbf{1 8}(\% 20,2)$ & \\
Kararsız & $9(\% 26,5)$ & $9(\% 27,3)$ & $2(\% 16,7)$ & $4(\% 44,4)$ & $0(\% 0,0)$ & $\mathbf{2 4}(\% 27,0)$ & \\
lyi & $13(\% 38,2)$ & $3(\% 9,1)$ & $2(\% 16,7)$ & $4(\% 44,4)$ & $0(\% 0,0)$ & $\mathbf{2 2}(\% 24,7)$ & \\
Çok iyi & $2(\% 5,9)$ & $4(\% 12,1)$ & $0(\% 0,0)$ & $0(\% 0,0)$ & $0(\% 0,0)$ & $\mathbf{6 ( \% 6 , 7 )}$ & \\
\hline TOPLAM & $\mathbf{3 4}(\% 38,2)$ & $\mathbf{3 3 ( \% 3 7 , 1 )}$ & $\mathbf{1 2}(\% 13,5)$ & $\mathbf{9 ( \% 1 0 , 1 )}$ & $\mathbf{1 ( \% 1 , 1 )}$ & $\mathbf{8 9}(\% 100)$ & \\
\hline
\end{tabular}

Ameliyathane ışıklandırma, gereksiz parlama ve göz alıcılığı önleyecek şekilde doğru tasarlanması

\begin{tabular}{|c|c|c|c|c|c|c|c|}
\hline Çok kötü & $3(\% 8,8)$ & $7(\% 21,2)$ & $1(\% 8,3)$ & $0(\% 0,0)$ & $0(\% 0,0)$ & $11(\% 12,4)$ & 0,144 \\
\hline Kötü & $4(\% 11,8)$ & $7(\% 21,2)$ & $7(\% 58,3)$ & $1(\% 11,1)$ & $0(\% 0,0)$ & $19(\% 21,3)$ & \\
\hline Kararsız & $10(\% 29,4)$ & $8(\% 24,2)$ & $1(\% 8,3)$ & $3(\% 33,3)$ & 1 (\%100) & $22(\% 24,7)$ & \\
\hline & $16(\% 47,1)$ & $9(\% 27,3)$ & $2(\% 16,7)$ & $5(\% 55,6)$ & $0(\% 0,0)$ & $33(\% 37,1)$ & \\
\hline Çok iyi & $1(\% 2,9)$ & $2(\% 6,1)$ & $1(\% 8,3)$ & $0(\% 0,0)$ & $0(\% 0,0)$ & $4(\% 4,5)$ & \\
\hline TOPLAM & $34(\% 38,2)$ & $33(\% 37,1)$ & $12(\% 13,5)$ & $9(\% 10,1)$ & $1(\% 1,1)$ & $89(\% 100)$ & \\
\hline \multicolumn{8}{|c|}{ Ameliyathane odalarının havalandırmasının iyi yapılması } \\
\hline Çok kötü & $11(\% 2,9)$ & $9(\% 27,3)$ & $3(\% 25,0)$ & $0(\% 0,0)$ & $0(\% 0,0)$ & $13(\% 14,6)$ & 0,027 \\
\hline Kötü & $5(\% 14,7)$ & $4(\% 12,1)$ & $5(\% 41,7)$ & $0(\% 0,0)$ & $0(\% 0,0)$ & $14(\% 15,7)$ & \\
\hline Kararsız & $10(\% 29,4)$ & $7(\% 21,2)$ & $2(\% 16,7)$ & $4(\% 44,4)$ & 1 (\%100) & $24(\% 27,0)$ & \\
\hline İyi & $11(\% 32,4)$ & $12(\% 36,4)$ & $2(\% 16,7)$ & $4(\% 44,4)$ & $0(\% 0,0)$ & $29(\% 32,6)$ & \\
\hline Çok iyi & $7(\% 20,6)$ & $1(\% 3,0)$ & $0(\% 0,0)$ & $1(\% 11,1)$ & $0(\% 0,0)$ & $9(\% 10,1)$ & \\
\hline TOPLAM & $34(\% 38,2)$ & $33(\% 37,1)$ & $12(\% 13,5)$ & $9(\% 10,1)$ & $1(\% 1,1)$ & $89(\% 100)$ & \\
\hline \multicolumn{8}{|c|}{ Ameliyathane odaları ses açısından izole edilmesi } \\
\hline Çok kötü & $6(\% 17,6)$ & $9(\% 27,3)$ & $3(\% 25,0)$ & $3(\% 33,3)$ & $0(\% 0,0)$ & $21(\% 23,6)$ & 0,762 \\
\hline Kötü & $15(\% 44,1)$ & $10(\% 30,3)$ & $7(\% 58,3)$ & $3(\% 33,3)$ & $0(\% 0,0)$ & $35(\% 39,3)$ & \\
\hline Kararsız & $8(\% 23,5)$ & $8(\% 24,2)$ & $2(\% 16,7)$ & $2(\% 22,2)$ & 1 (\%100) & $21(\% 23,6)$ & \\
\hline & $5(\% 14,7)$ & $4(\% 12,1)$ & $0(\% 0,0)$ & $1(\% 11,1)$ & $0(\% 0,0)$ & $10(\% 11,2)$ & \\
\hline Çok iyi & $0(\% 0,0)$ & $2(\% 6,1)$ & $0(\% 0,0)$ & $0(\% 0,0)$ & $0(\% 0,0)$ & $2(\% 2,2)$ & \\
\hline TOPLAM & $34(\% 38,2)$ & $33(\% 37,1)$ & $12(\% 13,5)$ & $9(\% 10,1)$ & $1(\% 1,1)$ & 89 (\%100) & \\
\hline
\end{tabular}

Ameliyathanede hastaların giriş kısmının gerçekleştiği ve hastalar-refakatçilerin bulunduğu anlarda refakatçiler için düzenleme durumuna verilen cevaplarda yaş gruplarına göre personelin verdiği cevaplarda anlamlı fark bulunmamaktadır $(p=0,260)$ (Tablo 19). 20-30 yaş \%18,2 (iyi \%15,2, çok iyi \%3,0), 31-40 yaş \%3,0 (iyi \%3,0), 51-60 yaş \%28,6 (iyi \%28,6) oranlarında olumlu düşünmektedirler. 20-30 yaş \%61,7 (kötü $\% 27,3$, çok kötü \%18,2), 31-40 yaş \%57,6 (kötü \%18,2, çok kötü \%45,5), 41-50 yaş \%83,3 (kötü \%33,3, çok kötü \%41,7), 51-60 yaş \%. 66,6 (kötü \%14,3, çok kötü \%57,1) oranlarda olumsuz görüş bildirmişlerdir (tablo 19). Toplamda \%31,4 ise karasız 
durumdadır. Refakatçilerin bulunduğu alanın yetersizliği açıktır. Bu çalışan tüm yaş grubundan personelin dikkat çektiği bir durumdur. Ameliyathane koridorları, bekleme alanları, hasta bekleme alanları gibi yerlerinde estetik ögelerin kullanılma durumuna verilen yanıtlarda yaş gruplarının cevapları arasında anlamlı fark bulunmamıştır $(p=0,877$ ) (Tablo 29). 20-30 yaş \%14,7 (iyi \%8,8, çok iyi $\% 5,9$ ), 31-40 yaş \%12,0 (iyi $\% 12,0$ ), $41-50$ yaş $\% 20,0$ (iyi \%20,0), 51-60 yaş \%22,0 (iyi \%22,0) oranlarında olumlu düşünmektedirler. 20-30 yaş \%55,9 (kötü \%32,4, çok kötü \%23,5), 31-40 yaş \%69,7 (kötü \%33,3, çok kötü \%36,4), 41-50 yaş \%60,0 (kötü \%40,0, çok kötü \%20,0), 51-60 yaş \%. 66,6 (kötü \%44,4, çok kötü \%22,2) oranlarda olumsuz görüşe sahiptirler (tablo 19). Toplamda \%21,8 ise karasız kalmıştır. Belirlenen alanlarda estetik ögelerin olmadığı kesindir. Bunun hijyen ve işlevsel olma ile ilgili olduğu düşünülmektedir. Ameliyathane ortamında güvenlik açısından önemli görülen çalışma ortamında düşmeler ile ilgili soruda yaş gruplarına göre personelin cevapları arasında anlamlı fark bulunamamıştır ( $p=0,319$ )(tablo 19$)$. 20-30 yaş $\% 26,5,31-40$ yaş $\% 42,4,41-50$ yaş $\% 50,0,51-60$ yaş \%55,6 oranlarında düştüklerini belirtmişlerdir. Yaş gruplarında ilerleme oldukça düşmelerin de arttığı görülmektedir. Bu durumun ilk sebebi mekânda bulunma oranının artması olabilir. İkinci sebebi ise yaş ile birlikte dikkat eksikliği olmasıdır. Mekân tasarımında ya da mekânda kullanılan malzemelerin özelliklerinin belirlenmesinde iç kullanıcı yaş faktörü de bir veri olarak değerlendirilebilir. Ayrıca düşme dışında yaşadıkları güvenlik problemlerine verilen cevaplar arasında da anlamlı fark bulunamamıştır $(p=0,178)$ (Tablo 19). Çalışmada yer alan yaş gruplarından 20-30 yaş $\% 14,7,31-40$ yaş $\% 18,2,41-50$ yaş $\% 50,0,51-60$ yaş $\% 55,6$ oranlarında güvenlikle ilgili farklı sıkıntılar da yaşadıklarını ifade etmişlerdir. Bu oranlar yaşamayanlara göre düşüktür (tablo 19). Az sayıda güvenlik problemlerinin sebepleri ise cerrahi aletlerin kesme-batması, cerrahi ekipman kablolarına takılma-dolaşma gibi sebeplerden kaynaklandığı sözlü olarak belirtilmiştir. Ameliyathanede çalışanların, işlev, güvenlik, estetik, rahatık ve mahremiyet konularında, mekândan beklentileri, yine iç kullanıcının mekânı oluşturmadaki katkısı olarak yorumlanmaktadır. İşlev, güvenlik, estetik, rahatlık ve mahremiyetin hangisinin ilk sırada olduğu belirlenmeye çalışımasına verilen cevaplarda yaş grupları arasında anlamlı fark bulunmamıştır $(p=0,281)$ (Tablo 19). İşlev; 20-30 yaş $\% 57,6,31-40$ yaş $\% 38,7,41-50$ yaş $\% 66,7,51-$ 60 yaş 44,4 ile tüm gruplarda ilk sırada yer alırken 31-40 yaş'ta yine \%38,7 ile güvenlikte ilk sıralardadır. Güvenlik; 20-30 yaş $\% 18,2,41-50$ yaş $\% 22,2,51-60$ yaş $\% 33,3$ oranları ile yaş gruplarında ikinci sıradadır. Rahatı; 20-30 yaş \%91,, 31-40 yaş $\% 12,9,41-50$ yaş \%11,1 oranları ile yaş grupları arasında üçüncü sıradadır. Estetik sadece 51-60 yaş grubunda \%22,2 ile üçüncü sırda yer alırken diğer gruplarda son sıradadır. Mahremiyet ve estetik ise gruplarda son sırada belirtilmiştir. burada 51-60 yaş aralığındaki çalışanların mekânda estetiğe bakış açıları diğer gruplardan daha farklı bulunmuştur.

Tablo 19: Ameliyathanede refakatçiler için gerekli düzenlemeler yapılması

20-30 yaş $\mathrm{n}(\%) \quad 31-40$ yaş $\mathrm{n}(\%) \quad 41-50$ yaş $\mathrm{n}(\%) \quad 51-60$ yaş $\mathrm{n}(\%) \quad 61-70$ yaş $\mathrm{n}(\%) \quad$ Toplam $\mathrm{n}(\%)$

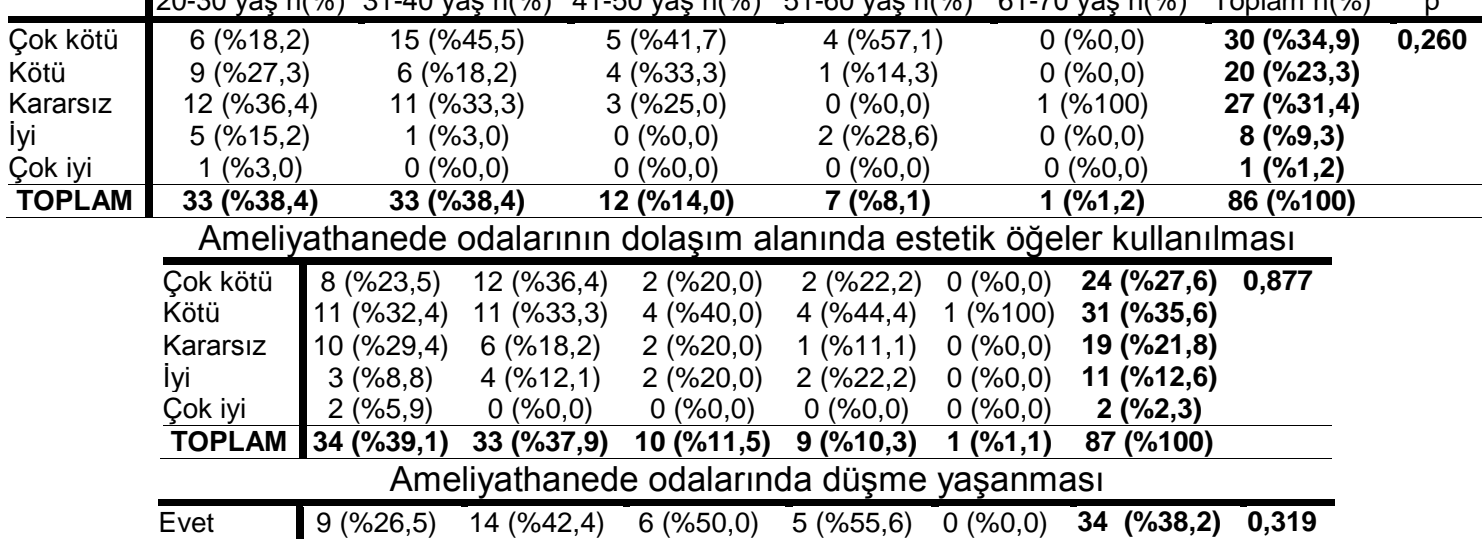




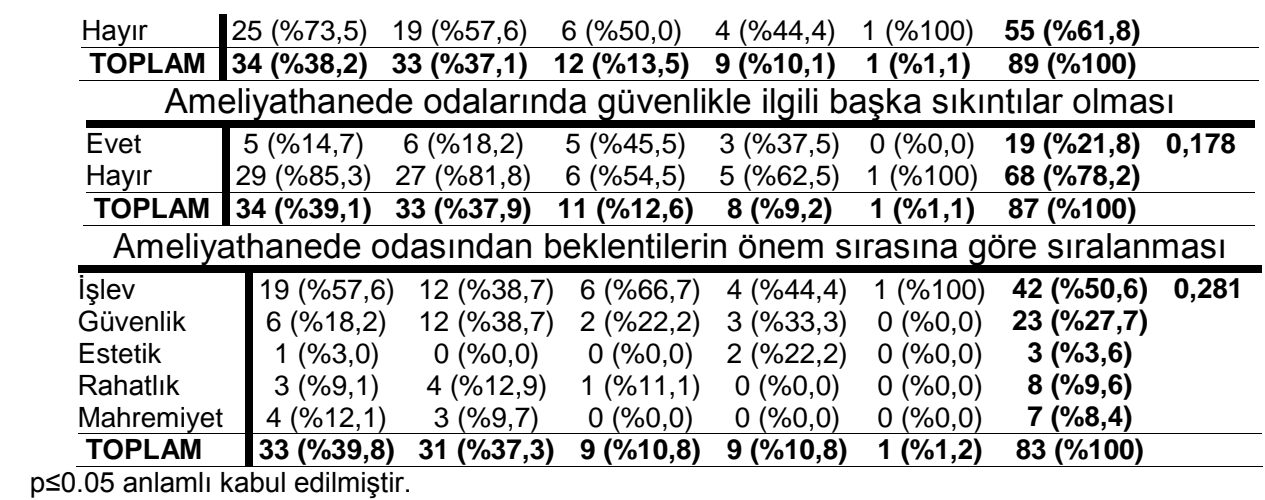

\section{Tartışma}

Hastanelerde iç ve dış kullanıcı olarak iki tip kullanıcı bulunmaktadır. Ameliyathanelerde de aynı durum geçerlidir. Ameliyathanelerde kullanıcılara yönelik yapılmış bir çalışmaya literatürde rastlanmamıştır. Bunun sebeplerinden ilk ameliyathanelerde bir çalışma yapabilmek için gerekli yasal prosedürün çok uzun zaman alması ve bu süreç sonunda olumsuz cevap alma durumunun olmasıdır. İkinci olarak ise steril ortama ameliyathane çalışanları dışında girmenin mümkün olamamasıdır. Çünkü hasta sağlığı en önemli konu olarak görülmektedir. Üçüncüsü ise hasta psikolojisi açısından sakıncalı görülmekte ve idari izin verilmemektedir. Dördüncü ise işlemlerin devam ettiği bir ameliyathane ortamında tıp dışındaki alanlardan olan mimari amaçlı bilimsel çalışmaların yapılması etik açıdan uygun görülmemektedir. Hasta hakları, çalışma alanı iş güvenlik kuralları ve çalışan hakları ön plana çıkmaktadır. Ayrıca bir diğer önemli konu ise ERÜ Tıp Fakültesi Gevher Nesibe Hastanesinin TS ve ISO yönetim sistemleri içerinde yönetim ve denetiminin Gerçekleştirilmesidir. Bu çalışma yapılırken tüm gerekli idari izinler, süreç uzun da olsa, alınmıştır. Hastane yönetimi, tıp fakültesi yönetimi ve ameliyathane yönetiminden geçen izin süreci sonunda çalışma gerçekleştirilmiştir. Ancak ameliyathane ortamına giriş, mimarlık akademik personeli açısından yine de mümkün olamamıştır. $O$ yüzden mimari projesine ulaşılmış, Ameliyathane akademik personel yardımı ile görseller elde edilerek anketlerin uygulaması sağlanmıştır. Bu durum tüm ameliyathaneler için geçerli olduğundan alanda literatüre ulaşım zorlaşmıştır. Bu çalışma, alanında bir ilk olarak görülmektedir. Ancak bu durum, çalışmanın zayıf yönünü de oluşturmuştur. Çünkü literatür sonucu ameliyathane iç kullanıcılarına yönelik bir anket uygulaması ile karşılaşılamadığından istatistiksel olarak power analiz yapılması söz konusu olamamıştır. O yüzden çalışmada toplanabilen tüm anketler istatiksel verilere dâhil edilmiştir. Kullanıcı sayısının fazla olması yönü ise çalışmanın artısı olarak değerlendirilebilir. Çalışma bundan sonra yapılabilecek diğer çalışmalarda power analiz için de temel olacaktır. Çalışma tüm alanların ameliyathane cerrahi odalarında çalışan doktor ve yardımcı personeli kapsayacak şekilde yapılmıştır. Bu açıdan çalışma; alanında tek olma özelliğine de sahiptir. İstatiksel verilerde çalışmanın eksikliği ise; SPSS programı ile analiz yapılırken başka bir çalışmaya ulaşılamadığı için bir örneklem grubu oluşturulamamasıdır. Çalışmada, tüm etik ve yasal izinler, ilgili kurum ilgili yönetim birimlerinden alınmıştır. Ameliyathane performans değerlendirmesi yapılan üç aşamalı çalışma; işlev, estetik, güvenlik bölümlerinden oluşmaktadır. Çalışmanın gerçekleştirildiği hastane ve ameliyathaneleri, son dönem yapılan Kayseri şehir hastanesi dışında, tüm İç Anadolu Bölgesi'ne hitap eden bir bölge hastanesidir. Bu durum çalışmayı değerli kılmaktadır. Çalışma; iç kullanıcının doktor ya da yardımcı personel olarak ayrıldığı mesleklerine, kadın erkek olarak cinsiyetlerine ve beş farklı yaş grubu olan yaş olmak üzere üç değişkene bağlı olarak incelenmiştir. 
- Buna göre; ameliyathane iç kullanıcı "cinsiyet" durumu sonuçları: Ameliyathane iç kullanıcı cinsiyetleri bir diğer önemli kriter olarak ele alınmıştır. İç kullanıcıların cinsiyetinin çalıştıkları mekânı algılamada farklılar yaratması düşünülmüş sonuçlar kadın ve erkek personel bağlamında değerlendirilmiştir. Çalışmada personelin cinsiyetlerinde doktor veya yardımcı personel olmasında konusunda anlamlı fark bulunmuştur $(p=0,040)$ Doktorlarda erkek yardımcı personelde ise çoğunlukla kadınların çalışıyor olması ağırlıklıdır. Yardımcı personelin pozisyonunda cinsiyetin kadın yada erkek olmasında $(p=0,013)$, ameliyathane cerrahi odalarının kullanıma uygun boyutlarda olma durumunda $(p=0,005)$, ameliyathane odalarının mahremiyet koruma düzeyinde $(p=0.009)$, mahremiyetin görsel ve işitsel olarak sağlanmasında $(p=0.009)$, ameliyathanede bulunan donanım ile cerrahi oda içerisinde hareket rahatlığı konusunda $(p=0,029)$, ameliyathanede kullanılan techizatın uygun olup olmadığı konusunda $(p=0,044)$ kadın ve erkekler arasında anlamlı fark vardır. Bunlara ek olarak ameliyathane iç ortam ısısal konforu konusunda $(p=0,038)$, ameliyathanede rahatsız edici kokulara yönelik önlem alınıp alınmasında $(p=0,038)$, Ameliyathane koridorları, bekleme alanları, hasta bekleme alanları gibi yerlerinde estetik ögelerin kullanılmasında $(p=0,028)$ çalışanların cinsiyetleri arasında anlamlı fark bulunmaktadır. Doktorların bulundukları akademik pozisyonda $(p=0,975)$, cinsiyet anlamlı fark yaratmamaktadır. Kadınlar da erkekler kadar akademik yükselmede yer almaktadırlar. Bu durum, tüm ülkeler arasında da önem arz eden ve Atatürk'ün tüm ülkelerden önce kadına verdiği doğal haklarını kullanmayı teşviki ile olan bir gelişmedir. Çalışmaya katılanların yaşlarında $(p=0,544)$, bulundukları mekânı kullanım sürelerine bağlı olarak mekânı tanımada $(p=0,552)$, ameliyathanede çalışılan bölümde $(p=0.053)$, cerrahi kısımlarda ameliyat masası vb cerrahi eşyalar için alanın yeterlilik durumu fikirlerinde $(p=0,69)$, yıkama/fırçalama (sterilizasyon) gibi işlemlerin yapıldığı alanın kullanıma uygunluğunda $(p=0,433)$ cinsiyetler arasında anlamlı farklar bulunmamaktadır. Ayrıca cerrahi birimin kullanım rahatlığında $(p=0,154)$, cerrahi alanların engelli bireylere uygunluğunda da $(p=0,301)$ kadın yada erkek olmanın fark yaratmadığı görülmüştür. Ameliyathanede gün ışığı alma durumunda $(p=0,285)$, ameliyathanede genel tüm odaların manzara ve dış alanlara bakmasında $(p=0,250)$, iç mekân tasarımının çalışanlar üzerindeki etkisinde $(p=0,081)$, ameliyathanede odaların renklerinin durumunun nötr-sıcaksoğuk olmasında $(p=0,511)$, kullanılan malzemelerin yüzey kaplamalarının pürüzsüz, hijyenik, kolay temizlenir ve estetik kaygıları olan malzemelerden olmasında $(p=0,073)$ cinsiyetler arası anlamlı fark yoktur. Buna ek olarak; cerrahi odalarda ve diğer odalarda estetik ögelerin yeterli ve doğru kullanımı $(p=0,280)$, malzeme seçimlerinin estetik olup olmaması $(p=0,147)$, yapay aydınlatma durumu $(p=0,757)$, iç ortam yapay havalandırma durumu $(p=0,285)$, ses izolasyon durumu $(p=0,468)$, gerekli alanların refakatçiler için düzenleme durumu $(p=0,531)$ konularında yine kadın ve erkek personel cevapları arasında anlamlı fark yoktur. Ameliyathane çalışma ortamı güvenliğinde özellikle düşmeler konusunda $(p=0,500)$ ve bunun dışındaki güvenlik problemleri konusunda $(p=0,536)$ kadın ve erkekler arasında fark yoktur. Mekân girdisi olarak İşlev, güvenlik, estetik, rahatlık ve mahremiyet konularından ilk sırada olanın belirlenmesinde $(p=0,912)$ yine cinsiyetler arası fark bulunmamaktadır. Kadın ve erkeler sıralamayı; işlev, güvenlik, rahatlık, mahremiyet ve estetik olarak vermişlerdir. Bu, mekândan iç kullanıcının beklentilerini de ortaya koymaktadır.

- İkinci olarak ameliyathane iç kullanıcı "yaş" durumu sonuçları: Çalışmada iç kullanıcı olan ameliyathane çalışanlarının yaşları konusunda anlamlı fark 
bulunmuştur ( $p=0,002)$. Doktorlar arasında Akademik piramidal örgütlenmenin yaş aralığına da yansıdığı görülmektedir. mekânı tanımakta önemli olan mekânı kullanım sürelerinde $(p=0.000)$ ve çalışmaya katılan doktorların yaş aralıklarında da $(p=0,000)$, fark vardır. Cerrahi odaların yıkama/fırçalama sterilizasyon alanlarının kullanıma uygun tasarlanması $(p=0,031)$, Ameliyathane odaların gün ışığı alma durumu $(p=0,000)$, manzara görme-dış ortam ile ilişkili olma durumu $(p=0,001)$, kullanılan malzemelerin yüzey kaplamalarının pürüzsüz, hijyenik, kolay temizlenir ve estetik kaygıları olan malzemelerden olması durumu $(p=0,004)$, odaların yapay havalandırma durumu $(p=0,027)$ hakkında yaş grupları arasında farklar bulunmaktadır. Doktorların tersine yardımcı personelin yaş aralıklarında ise anlamlı fark bulunmamaktadır $(p=0,123)$. Çalışanların ameliyathanede çalıştığı bölüm $(p=0.364)$, cerrahi odalarının kullanıma uygun boyutlarda olması $(p=0.239)$, mahremiyet koruma düzeyi değerlendirmesi $(p=0,818)$, mahremiyetinin işitsel ve görsel açıdan sağlama durumu $(p=0,853)$, ameliyathane odalarının içinde bulunan eşyalar ile ele alındığında alanın yeterliliği $(p=0,310)$, ameliyathane odalarının içerisinde bulunması gereken teçhizat ile rahat hareket etme durumu $(p=0,372)$, ameliyathanede kullanılan malzemelerin uygunluğu $(p=0,443)$, ameliyathane odasının herkes tarafından kolay kullanımının düşünülmüş olması $(p=0,756)$ konularında yaş grupları arasında fark bulunmamaktadır. Ameliyathanenin engelli kişilere yönelik tasarlanması konusunda $(p=0,366)$, iç mekan tasarımının çalışanlar üzerindeki etkisinde $(p=0,057)$, ameliyathanede sıcak-soğuk-nötr olarak belirlenen renklerin durumunda $(p=0,876)$ a Ameliyathane cerrahi odalarda ve diğer odalarda estetik ögelerin yeterli ve doğru kullanımında $(p=0,736)$, malzeme seçimlerinin estetik olup olmamasında $(p=0,245)$ da yaş aralıkları arasında fark yoktur. Bunlarla birlikte ameliyathane iç ortam ısısal konforu $(p=0,909)$, iç ortam hava kalitesinde $(p=0,125)$, ameliyathane aydınlatma, parlama ve göz almaya yönelik tasarımda $(p=0,144)$, ses izolasyonunun durumunda $(p=0,762)$ yaş grupları arasında fark görülmemiştir. Ameliyathanede refakatçiler için düzenlenen alan durumu $(p=0,260)$, ameliyathane koridorları, bekleme alanları, hasta bekleme alanları gibi yerlerinde estetik ögelerin kullanılma durumu $(p=0,877)$, güvenlik açısından önemli görülen çalışma ortamında düşme durumu $(p=0,319)$, düşme dışında yaşadıkları güvenlik problemleri $(p=0,178)$ konularında yaş grupları arasında fark olmadığı görülmüştür. İç kullanıcının mekânı oluşturmadaki katkısı; işlev, güvenlik, estetik, rahatlık ve mahremiyet konularında mekândan beklentilerini ortaya koymak olarak yorumlanmıştır. Burada da yaş grupları arasında fark yoktur $(p=0,281)$. Yaş gruplarında bu kavramlardaki sıralama; işlev, güvenlik, rahatlık, mahremiyet ve estetik olarak ortaya çıkmıştır.

\section{Sonuç}

Hastaneler, insanların yaşam standartları dışında olağan üstü durumlar için kullanılan özellikli mekânlar olurken, hastaneler içerisindeki birimlerden ameliyathaneler ve servis mekânları daha da özel tasarıları, yapımları, teçhizat ve çalışma ortamı yaratan mekânlar olarak görülmektedir. Ameliyathanelerde gelişen teknoloji ile birlikte değişen ve halen süren bir devinim olmaktadır. Bununla birlikte cerrahi hizmetlerden ve buna bağıı olarak mekânlardan da beklentiler artmıştır. Ayrıca farklı hastalaıkların müdahalesi sırasında farklı teçhizat ve teknolojik gelişmelerden dolayı mekansal farklıııklarla da karşılaşılmaktadır. Ameliyathaneler, mekanda koruması gereken steril ortam, mahremiyet gibi konular sebebi ile mimari alana yönelik akademik araştırmaların sınırlı kaldığı bir alan olmuştur. Ameliyathanelere yönelik yapılan çalışmalarda farklı tıbbi alanlara yönelik olarak yeni geliştirilen teçhizatın kullanımı ve kaç kişinin 
kullandığına dair tıbbi çalışmalardan öteye giden bir veriye de rastlanamamaktadır. Halbuki bu mekanı kullana kullanıcıların performans değerlendirmeleri mimari açıdan gelişim ve değişim için önemli veriler olmaktadır. Bu çalışmada hastane içerisinde özellikli alan olan ameliyathane iç kullanıcıları olarak tanımlana akademik ve idari personelden elde edilen verilerin alana önemli katkı koyacağı açıktır. Ameliyathane iç kullanıcılarının mekanları uzun süreli kullanmaları söz konusur. Bu da analizde kullanıcının doğru yanıtlar vermesini güçlendirmiştir. İç kullanıcıların yaptıkları işlemler farklı olduğu için mekân algılarının ve performans değerlendirmelerinin de farklılaşacağı açıktır. Bu yüzden bu çalışmada iç kullanıcıların doktor ve yardımcı personel olarak ele alınıp aralarında anlamlı farların olup olmaması da değerlendirilmişti. Buna ek olarak iç kullanıcının yaş ve cinsiyetinin de önemli olduğu düşünülmüştür. Fakat bu çalışmada değerlendirilmemiş bundan sonraki çalışmamalarda değerlendirilmesi hedeflenmiştir. İnsanların, normal yaşam aktivitelerinin bozulduğu dönemlerde kullandığı ve günlük yaşam alanlarından ve biçimlerinden farklı bir mekânda geçirmek zorunda kaldığı hastaneler ile ilgili algılarının, olumsuz olacağı açıktır. Bir de dış kullanıcı olan hastaların ameliyat ortamındaki algıları daha da olumsuz olacaktır. Bu yüzden bu çalışma kapsamında dış kullanıcı olan, ameliyat psikoloji içerisindeki, büyük ihtimal aç, uykusuz, huzursuz ve yatar pozisyonda bulunan hastalara, ameliyat öncesi ya da sonrası, anket uygulamak sağlıklı sonuçlar doğurmayacaktır. Ayrıca hastaların alacağı ameliyata yönelik tıbbı ilaçların etkisi de bu durumu zorlaştıracağı ve hastaların çok çok kısıtı zaman diliminde burada bulunacakları, kesinlikle anket uygulamasının yapılması sakıncalı ve sağlıksız sonuçlar vereceği düşünülerek, dış kullanıcı olan hastalara anket uygulanmıştır. Bu bilinçli bir tercihtir. Bundan sonra yapılacak çalışmalarda da buna dikkat edilmesi önerilmektedir. Genel yanılgılardan bir diğeri ise kullanıcı olarak sadece hasta ve hasta yakınları ele alınarak çalışmaların yapılmasıdır. Mekân kullanıcıları arasında o mekânda çalışanların da mekân hakkındaki görüşleri önemlidir ve mekânı belirleyici olarak düşünülmelidir. Özellikle ameliyathane çalışanlarının çalışma durumları, mekân performansı üzerindeki görüşlerini etkilemektedir. Sonuç olarak; incelenen ameliyathanede mekân boyutları olumlu görülmektedir. Mekân boyutlarının belirlenmesinde Sağlık Bakanlığı'nın yayınladığı boyutlandırma dikkate alınmış olduğu anlaşılmaktadır. Ancak ilerleyen tıbbi teknoloji ile robotik operasyonlar için mevcut alanlarda sıkıntı çıkacaktır. Ameliyathaneler, an itibari ile robotik ameliyatlar gerçekleştirilmediği için yeterli boyutlardadır. Bunun tersi bir şekilde, ameliyathanede cerrahi kısımlarda ameliyat masası vb cerrahi eşyalar için alan doktor ve yardımcı personel gruplarınca yeterli görülmemiştir. Burada çalışılan cerrahi birimin önemli olduğu düşünülmektedir. Gelecek kaygıları ile mutlaka cerrahi odaların boyutlarının büyütülmesi önerilmektedir.

Görsel ve işitsel mahremiyet ise doktor-yardımcı personel, yaş grupları, kadın-erkek personel tarafından yetersiz görülmektedir. Ameliyathane kaba ve ince yapı malzemelerinin seçiminde görsel ve işitsel malzeme seçimine mahremiyet açısından da dikkat edilmelidir. Müdahale öncesi dezenfeksiyonun gerçekleştiği alan ve özellikleri ise iki veya üç ameliyathanenin birlikte kullandığı alanlar olmasına rağmen yeterli düzeydedir. Bu boyutların sürdürülmesi önemlidir. Doktorlar cerrahi birimlerin kullanımı yapılan işlemlere göre rahat bulurken yardımcı personel daha olumsuz görüş bildirmiştir. Burada doktorların sabit çalışması ile yardımcı personelin daha hareketli çalışmasındaki farktan kaynaklı durum söz konusudur. Ayrıca yaş gruplarına göre genç olan yaştakilerin yapılan iş ve mekân uygunluğu deneyimlerinin olmadığı da görülmektedir. Her halükarda mekânlarda büyüme önerilmektedir. İncelenen alanda engelli bir ameliyathane çalışanı olmamasına rağmen mekânların engellilere göre tasarlanması önemli görülmektedir. Ameliyathanenin engelli bireylerin kullanımına uygun olmadığı tüm değişken gruplar içerisindeki kullanıcı tarafından belirtmiştir. 
Engelli bireyler doktor, yardımcı personel olamaz ya da kimse yaşlanmayacak diye bir şey olamaz. Ayrıca engelli hasta da gelmektedir. Mutlaka her mekânın olduğu gibi ameliyathanenin de engelli bireylere göre düzenlemesi yapılmalıdır. İncelenen ameliyathaneler de buna göre gözden geçirilerek gerekli düzenleme yapılmalıdır. Ameliyathanenin gün ışığı alması çalışanların her değişkeni grubu tarafından da yetersiz bulunmuştur. Cerrahi odalar dışında servis alanları, doktor odaları, dinlenme alanlarının gün ışığı alması, mümkün ise, sağlanmalıdır. Bu, çalışan sağlığı için önemlidir. Yine cerrahi odalar dışında servis alanları, doktor odaları, dinlenme alanlarının dış açık alanlara bakmadığı belirtilmiştir. $\mathrm{Bu}$, olumsuz olarak yorumlanmaktadır. Belirtilen alanlarda dış açık mekânlar ile görsel bağlantının olması için gerekli tasarım yapılmalıdır. Çalışanların çalıştıkları ortamı benimsemeleri önemlidir. Ameliyathane iç mekân tasarımının çalışanlar üzerinde etkisi, iç kullanıcı tarafından olumsuz olarak değerlendirilmiştir. Ameliyathane iç mekân tasarımı için araştırmalar yapılarak uygulamada çalışan düşüncelerinin de alınması gereklidir. Özellikle ortak kullanım alanları, dinlenme alanları ve doktor odaları için tasarımlar yapılmalıdır. Ameliyathane mekân renkleri her gruplamaya giren iç kullanıcılar tarafından soğuk ve nötr renkler olarak belirlenmiştir. Burada ameliyathane steril ortamına uygun renk seçimi yapıldığı görülmektedir. Ancak ortak kullanım alanları, dinlenme alanları ve doktor odaları için sıcak renkler seçilmesi de uygun olabilir. Ameliyathanede kullanılan mobilya yatak vb. cerrahi için gerekli donanım gibi malzemenin yüzey kaplamalarının ise pürüzsüz ve hijyenik seçimler ile yapılması gerekliliği söylenmiştir. Bu da uygun bir seçim olarak her farklı gruplama için de olumlu görülmüştür. Yardımcı personel yaptıkları işler gereği aynı zamanda kolay temizlenebilirliği de önemli görmüşlerdir. Doktorlar az bir oranla estetik kaygı da gütmektedirler. Mekânın işlevine göre malzeme seçiminde öncelik hijyen ve temizlik için olmalıdır. Eğer olabiliyor ise estetik kaygılar güdülmelidir. Cerrahi oda ve diğer mekânlarda estetik ögelerin kullanımı tüm gruplar için yetersiz bulunmuştur. Özellikle doktor odaları, dinlenme alanları gibi mekânlarda estetik ögeler kullanılabilir. Sürekli işlev düşünülerek yaklaşılan mekânların canlandırılması açısından önerilmektedir. Bu durum genel tüm ameliyathane için aynı görülmektedir. Ameliyathane iç ortam ISıSı doktor ve yardımcı personelin çoğunluğunca iyi bulunsa da personelin yaş ve cinsiyet değişkenine göre sorgulandığında; bir kısmı olumsuz düşünmüştür. Mutlaka iç ortam ısı ölçümleri yapılmalıdır. Buna göre cerrahi odalar ve diğer mekânların ortam ısıları yapılan işe göre ayarlanmalıdır. Bu yapılırken iç kullanıcı olan personelin yaş ve cinsiyet gibi kişisel verileri de göz önüne alınmalıdır. Diğer önemli konu ise ameliyathane aydınlatma, parlama ve göz almaya yönelik tasarımlardır. Doktorlar, yardımcı personele göre daha olumlu yaklaşmışlardır. Çünkü cerrahi müdahaleyi gerçekleştiren ana grup olduklarından kullanılan aydınlatmayı yeterli görmüşlerdir. Yaş gruplarında ise ilerleyen yaşlarda olumsuz bildirimler görülmüştür. Burada da yine ortam aydınlatma ölçümlerinin yapılması ve varsa problemlerin giderilmesi gereklidir. $\mathrm{Bu}$ yapılırken yine personelin yaş ve cinsiyet gibi kişisel verileri de göz önüne alınmalıdır. Ameliyathane ses izolasyonu hasta ve çalışan konforu için önemli bir konudur. Doktor ve yardımcı personel, kadın-erkek personel, yaş gruplarında değerlendirilen personelin hepsi ses izolasyonunun kötü olduğu konusunda hem fikirdir. Ortam ölçümleri yapılmalı ve gerekli ses izolasyonu birimler arasında sağlanmalıdır. Yine yaş ve cinsiyet verileri de değerlendirmede göz önünde bulundurulmalıdır. Ameliyathanede hasta yakınlarının bulunduğu alan düzenlemesi yeterli görülmemiştir. Refakatçiler için mekân düzenlemesi, refakatçinin hasta yanına girmesi gereken durumlar düşünülerek yapılmalı ve refakatçinin de steril ortamdan uzak tutulurken konforu düşünülmelidir. Bu; doktora-yardımcı personeleameliyathaneye vb güveni artıracak ve refakatçinin gergin ortamda rahatlamasını sağlayacak bir durumdur. Ameliyathane koridorları, bekleme alanları, hasta bekleme alanları gibi yerlerinde estetik ögelerin kullanılma durumuna tüm gruplamalar da 
Ameliyathane Performanslarının İç Kullanıcı Memnuniyeti Açısından İncelenmesi; Erciyes Üniversitesi Gevher Nesibe Hastanesi Örneği Investigation of Operating Room Performances in Terms of Internal User Satisfaction; an Example of a University Hospital

olumsuz cevap vermiştir. Gerekli sterilizasyonu bozmayacak ve sürdürülebilirliğini sağlamada problem çıkarmayacak estetik ögelerin kullanılması iyi olacaktır.

İş güvenliği çalışanlar açısından önemlidir.Hâlihazırda zaten çok tehlikeli iş sınıfında yer alan ameliyathanelerde bunu yükseltici başka bir şey olmaması gerekir. O yüzden mekân ile ilgili olarak düşme durumu da irdelenmiştir. İç kullanıcı olan ameliyathane çalışanları çoğunlukla düşmediklerini belirtse de düşme vakaları da azımsanmayacak orandadır. Özellikle yaş grupları ilerledikçe mekânı kullanma süreleri yıl bazında arttığı için düşme olayı ile karşılaşmaları da artmıştır. Düşmeler kayma ve kablolara takılma sebebi ile olmaktadır. Kablolar için kesinlikler gerekli tedbirler alınmalıdır. Zemin kaplamasında kullanılan malzeme ameliyathane için uygun malzemedir. Kaymalarda çoğunlukla yardımcı personel tarafından giyilen terliklerin ucuz ve ameliyathane koşullarına uygun olmadığı düşünülmektedir. Eğer kendileri bu malzemeyi sağlayamıyor ise hastane yönetimince sağlanması ve zemin malzemesinin yine aynı malzeme olarak korunması önerilmektedir. Ameliyathanede cerrahi odalarda mahremiyet koruma düzeyinde doktor ve yardımcı personel farklı düşünmektedir. Yaptıkları iş kaynaklı, aldıkları eğitim ve buna göre şekillenen bakış açısı sebebi vb nedenlerle böyle düşünmektedirler. Ancak şu gerçektir ki bu konuda da hasta mahremiyeti düşünülmeli gerekli düzenlemelerin yapılması sağlanmalıdır. Yaş grupları ve kadın-erkek cinsiyet grupları açısından incelendiğinde mekânın mahremiyeti sağlaması konusunda olumsuz görüştedirler. Ameliyathanede bulunan donanım ile cerrahi oda içerisinde hareket rahatlığında yine yapılan iş kaynaklı farklı düşünceler olmuştur. Sadece cerrahi işlemi gerçekleştiren doktorlar düşünülerek mekân tasarımı yapılmamalı aynı zamanda cerrahi odalar, yardımcı personelin oda içerisinde rahat çalışmasını sağlayacak boyutlarda tasarlanmalıdır. Bu duruma gelişen teknoloji düşünülerek yaklaşımalıdır. Ameliyathanede kullanılan teçhizat doktorlarca uygun yorumlanırken yardımcı personel tersini düşünmektedir. Yine yapılan iş kaynaklı bir ayrım söz konusudur. Teçhizat alımlarında mutlaka her iki meslek grubunun görüşlerinin alınması iş güvenliğinin de konusudur. Her çalışan için uygun olması beklenmektedir. Ortam içerisinde rahatsız edici kokuların olması konusunda yardımcı personel olumsuz yaklaşmıştır. Ortamın iç hava kalitesini düşük bulmuşlardır. Doktorların özellikle anestezi dışında kalan bir kısmı yardımcı personele oranla daha az ameliyathane ortamında bulunmaktadır. Bu yüzden konu üzerinde olumlu oldukları düşünülmektedir. Yaş ve cinsiyet gruplandırmalarında da olumsuz görüşler çıkmıştır. Ortam ölçümleri yapılmalı ve bu yapılırken çalışan cinsiyeti ve yaşı da veri olarak değerlendirilmelidir. Özellikle dinlenme alanlarının düzenlemesinde yardımcı personel görüşleri dikkate alınmalıdır. Buna bağlı olarak yapay havalandırma durumunda da doktor ve yardımcı personel arasında aynı şartlardan dolayı fark çıkmıştır. Ortam ölçümlerine göre gerekli mekanik sistem düzenlemesi de yapılmalıdır. Bunun için yeterli alt yapı düşünülmeli ve bunun mimari tasarıma olan verileri değerlendirilerek mekân boyutlandırımalıdır. İşlev, güvenlik, estetik, rahatlık ve mahretmiyet konularından hangisinin ilk sırada olduğu belirlenmeye çalışılmıştır. Doktor ve yardımcı personelin yine yaptıkları iş, eğitim, bakış açısı gibi etkilerle mekana yaklaştıkları düşünülmektedir. Doktorlar ameliyathanedeki tüm mekanlarda; işlev, güvenlik, rahatılık, estetik sıralamasını yapmışlardır. Yardımcı personel ise; güvenlik, işlev, mahremiyet önemli olmuştur. Estetik konusuna yardımcı personel hiç önem vermemektedir. Yaş gruplarında ve cinsiyet gruplarında ise işlev, güvenlik, rahatık, mahremiyet, estetik sıralaması ortaya çıkmıştır. Burada, işlev ve güvenlik ana konular olduğu için mekan tasarımlarında öne çıkması gereken özellikler olarak belirlenmelidir. Çalışmada incelenen Erciyes üniversitesi Tıp Fakültesi Gevher Nesibe Hastanesi ameliyathaneleri, genelde, olumlu özelliklere sahip olduğu belirlenmiştir. Buna rağmen; yukarıda bahsi geçen düzenlemelerin yapılması gereklidir. Kullanıcıları mekân konusunda ve iş güvenliği-mekân ilişkisi konusunda bilinçlendirilmesi de gereklidir. Alan incelemesinde 
seçilen bölgenin en büyük hastanesinin ameliyathanesindeki elde edilen sonuçların genel olarak diğer aynı özelliklere sahip ameliyathaneler için de geçerliliği bulunmaktadır. Çalışmanın, kullanıcı memnuniyeti, mekanların işlev açısından sürdürülebilirliği, kalite kavramı ve bundan sonra yapılacak çalışmalara katkıda bulunması umulmaktadır. Elde edilen sonuçların, yetkili makamlarca da dikkate alınarak, yasal mevzuatlara geçirilmesi, mekân uygulamalarının ve tasarımlarının da buna göre gerçekleştirilmesi gereklidir.

Teşekkür Araştırmanın istatistiksel analizleri için Erciyes Üniversitesi Tıp Fakültesi, Anestezi ve Reanimasyon ABD Öğretim Üyesi Prof. Dr. Recep Aksu'ya ve bu çalışmaya katılmayı kabul eden Erciyes Üniversitesi Tıp Fakültesi Gevher Nesibe hastanesi ameliyathane personeline katkılarından dolayı teşekkürlerimizi sunuyoruz.

\section{Kaynaklar}

Aslan Ş., Özata M., (2005). "Poliklinik Hastalarının Müşteri Memnuniyetini Belirlemeye Yönelik Ampirik Bir Çalışma"; (An Empirical Study to Determine the Customer Satisfaction of Outpatient Clinic Patients),Konya Kamu Hastaneleri Örneği. Sağlık ve Hastane Yönetimi 2. Ulusal Kongresi Bildiriler Kitabı, Ankara, sayfa: 554-565,

Argeus Mimarlık Ltd. Şti., (2016). "Erciyes Üniversitesi Gevher Nesibe Hastenesi, Rölöve-Restorasyon projesi", (Erciyes University Gevher Nesibe Hospital, SurveyRestoration project ), Kayseri

Bayar M., (1994). "Hastane ve Muayene Odalarının Görsel Konfor Koşulları Açısından Değerlendirilmesi", (Evaluation of Hospitals and Examination Rooms in terms of Visual Comfort Conditions ), Y.T.Ü., Fen Bilimleri Enstitüsü, Y.Lisans Tezi, İstanbul, sayfa: 7779

Biçer, C., (2020). "ERÜ Ameliyathaneleri Kişisel Fotoğraf arşivi", (Personal Photo archive of ERU Operating Rooms), Kayseri

Biçer T., Bebiş H., İnanç N., (2001). "Temel Sağlık Hizmetleri ve Toplum Sağlığı, Hemşireliği Eğitiminin İrdelenmesi”, (Primary Health Care and Community Health, Examining Nursing Education), Hemşirelik Forumu, sayfa: 4:26-31

Çıraklı Z. L., Sayım F., (2009). 'Hastanelerdeki Sağlık Hizmetlerinde Kalite Yönetim Sistemlerinin Maliyet Fayda, Maliyet Etkililik Analizi Göstergelerinin İncelenmesi', (Investigation of Cost Benefit, Cost Effectiveness Analysis Indicators of Quality Management Systems in Health Services in Hospitals.), Uluslar Arası Sağlıkta ve Kalite Performans Kongresi, 19-21 Mart, Antalya

Çoruh M., (1998). Hastanelerde Kalite Belgesi Alma Girişimi Ve Ötesi, Modern Hastane Yönetimi, (Initiative And Beyond Getting Quality Certificate In Hospitals, Modern Hospital Management ), sayı:4, İstanbul, Sayfa4-5

Ergenoğlu S.A., Aytuğ A., (2007). "Sağlık Kurumlarında Değişen Paradigmalar ve İyileştiren Hastane Kavramının Mimari Tasarım Açısından İrdelenmesi”, (Changing Paradigms in Healthcare Institutions and Examining the Concept of Healing Hospital in Terms of Architectural Design ), Megaron, cilt 2, sayı 1, sayfa, 44-63

Ergenoğlu S. A., Tanrıtanır A., (2013). "Genel Hastanelerde Kullanıcı Memnuniyeti Açısından Hasta Odalarında Mimari Mekan Kalitesinin İrdelenmesi: Gaziantep İlinde 
Bir Alan Çalışması",( Investigation of Architectural Space Quality in Patient Rooms in Terms of User Satisfaction in General Hospitals: A Field Study in Gaziantep Province ),Megaron, cilt8, sayı2, sayfa 61-75

Gezer H., (2014). "Hastanelerde Ve Sağlık Merkezlerinde Erişelebilirlik", (Accessibility in Hospitals and Health Centers), İstanbul Ticaret Üniversitesi Fen Bilimleri Dergisi, Sayı: 25, İstanbul, sayfa: 113-133,

Kavuncubaşı Ş., (2000). "Hastane Ve Sağlık Kurumları Yönetimi", (Hospital And Healthcare Management), Siyasal Kitapevi, sayfa: 399

Strasen L., (1988). "Incorporating patient satisfaction standarts in to quality of care measures", J Nurs Admin;18:5-6

Şentürk F., (1994). "Hastane Ortamında Gürültü Etkenleri ve Hastaların Bu Konudaki Görüşleri", (Noise Factors in Hospital Environment and Patients' Opinions on this Issue),Bilim Uzmanlığı Tezi, Hacettepe Üniversitesi, Sağıık Bilimleri Enstitüsü, Ankara, sayfa: $28-31$,

Tarım M., (2000). “ Hizmet Organizasyonlarında(Hastanelerde) Kalite",( Quality in Service Organizations (Hospitals)) Prof. Dr. Nusret Ekin'e Armağan, Türk Ağır Sanayii ve Hizmet Sektörü Kamu İşverenleri Sendikası Yayını, No:38, Ankara, sayfa:1027

T.C. Sağlık Bakanlığı İnşaat ve Onarım Dairesi Başkanlığı, (2019). (Türkiye Sağlık Yapıları Asgari Tasarım Standartları 2010 Yılı Kılavuzu,)., (Turkey Health Buildings Minimum Design Standards Manual 2010), Ankara

Tezcan S, Altınbaş H, Yeşildal N., (2000). Satisfaction study ofpatients and their relatives visiting İhsan Doğramacı Children's Hospital of Hacettepe University School of Medicine. International public health congress "health 21 in action" abstracts book, October 8-12, İstanbul-Turkey, Sayfa:47

Tüker Ç., (1996). "An Analysis of General Hospitals and Developments Affecting Change in Desing" Master of Thesis, The Middle East Technical University, The Department of Architecture, v-vi, Ankara

Yıldırım K., Muslu S. M., (2006). "Poliklinik Bekleme Alanlarında Çevresel Faktörlerin Kullanıcıların Fonksiyonel ve Algı-Davranışsal Performansına Etkisi: Gazi Hastanesi Çocuk Poliklinikliği", (The Effect of Environmental Factors on the Functional and Perception-Behavioral Performance of Users in Polyclinic Waiting Areas: Gazi Hospital Child Polyclinic), cilt:9, sayı:1, sayfa,39-51

\section{İnternet Atıfları:}

URL-1 Aydın B., (2008). "Akreditasyon ve Hasta Güvenliği”. (Accreditation and Patient Safety), http://www.hastaguvenligi.org/author_article_detail.php?id=1, Erişim: 3 Şubat 2011

URL-2 Andrew M. Ibrahim, Justin B. Dimick, and Anjali Joseph, (2017). "Building a Better Operating Room Views from Surgery and Architecture", Annals of Surgery _ Volume 265, Number 1, January 2017, file://C:/Documents\%20and\%20Settings/Administrator/Belgelerim/Downloads/Building _a_Better_Operating_Room_Views_from.8.pdf). 
URL-3 Springer, (2020). https://link.springer.com/article/10.1007/s00464-014-3984x/figures/1?shared-article-renderer, erişim: şubat 2020

URL-4 Pinterest, (2020), https://tr.pinterest.com/pin/536561743096920833/, erişim: şubat 2020

URL-5 The Forum, (2009). [Epub June 2009] doi: 10.1532/HSF98.20091033 Planning a Cardiovascular Hybrid Operating Room: the Technical Point of View Georg Nollert,1,2 Sabine Wich1 1 Siemens AG Healthcare Sector, Angiography, Fluoroscopic and Radiographic Systems, Forchheim, Germany; 2 Clinic of Cardiac Surgery, University of Munich, Germany Presented at the 4th Integrated Coronary Revascularization (ICR) Workshop for Interventional Cardiologists and Cardiac Surgeons, Innsbruck, Austria, December 4-6, 2008. Correspondence: Georg Nollert, Siemens AG, Healthcare Sector, Imaging \& IT Division, Angiographic, Fluoroscopic, and Radiographic Systems, H IM AX CRM OR, Siemens Str. 1, 91301 Forchheim, Germany; +49 (9191) 18-9501; fax: +49 (9191) 18-0014 (e-mail: georg.nollert@siemens.com). \#2009-1033 12 (3), Online address: http://cardenjennings.metapress.com, erişim: şubat 2020

URL-6 Warren S. Sandberg, Bethany Daily, M.H.A., Marie Egan, R.N., M.S., James E. Stahl, M.D., C.M., M.P.H., Julian M. Goldman, M.D., Richard A. Wiklund, M.D., David Rattner, M.D., (2005). (file:///C:/Documents\%20and\%20Settings/Administrator/Desktop /yapilacak\%20calismalar/ameliyat\%20hane/Anes103-406_ORF_Redes.pdf Anesthesiology 2005; 103:406-18 @ 2005 American Society of Anesthesiologists, Inc. Lippincott Williams \& Wilkins, Inc. Deliberate Perioperative Systems Design Improves Operating Room Throughput Warren S. Sandberg, M.D., Ph.D., ${ }^{*}$ Bethany Daily, M.H.A., † Marie Egan, R.N., M.S., $\ddagger$ James E. Stahl, M.D., C.M., M.P.H.,§ Julian M. Goldman, M.D., Richard A. Wiklund, M.D.,\# David Rattner, M.D.). , erişim: şubat 2020

URL-8 Google, (2020). www.earth.com, 2016, Erciyes Üniversitesi Haritası, Erişim: 12.03.2020 